
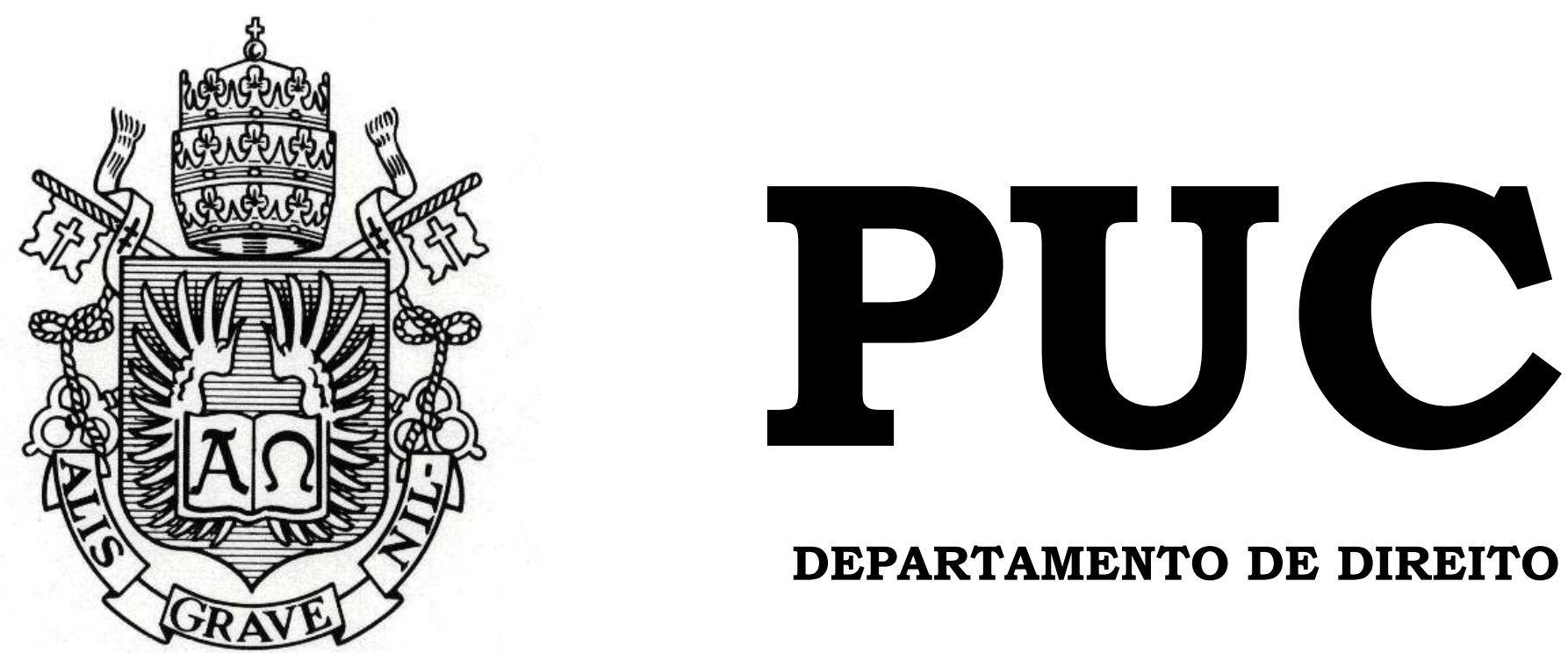

DEPARTAMENTO DE DIREITO

\title{
A LEGITIMAÇÃO DA POSSE: OBSTÁCULOS E POSSIBILIDADES PARA A TUTELA DO DIREITO DE MORADIA
}

por

PALOMA DE AZEVEDO CORRÊA

ORIENTADORA: Rosângela Lunardelli Cavallazzi 2010.2 


\section{A LEGITIMAÇÃO DA POSSE: OBSTÁCULOS E POSSIBILIDADES PARA A TUTELA DO DIREITO DE MORADIA}

por

PALOMA DE AZEVEDO CORRÊA

Monografia apresentada ao Departamento de Direito da Pontifícia Universidade Católica do Rio de Janeiro (PUC-Rio) para a obtenção do Título de Bacharel em Direito.

Orientadora: Rosangela Lunardelli Cavallazzi 
Dedico esta monografia a meu querido avô.

\section{Agradecimentos}

Agradeço a meu pai que luta pela habitação popular, a minha mãe arquiteta, a minha avó paterna que compreendeu minha ausência nestes últimos tempos em razão deste trabalho e a minha avó materna sempre atenciosa e a minha orientadora Rosangela Cavallazzi. 
Resumo

$\mathrm{O}$ presente trabalho pretende promover a discussão a respeito do instrumento jurídico e urbanístico da Legitimação da Posse, recentemente, incorporado ao ordenamento pátrio como parte da política urbana por forca da Lei 11977 de 2009.

Palavras chave

Direito de moradia - Direito à cidade - Constituição de 1988 - Estatuto da Cidade - Regularização fundiária - Ocupações Irregulares - Direito à Propriedade - Função social da propriedade - Posse - Função social da posse - Instrumentos Jurídicos de regularização fundiária - Legitimação da Posse - Lei 11977 de 2009 - Procedimento Administrativo da Legitimação da Posse 
SUMÁRIO

\section{Capitulo 1}

1.1. Introdução

Delimitação teórico conceitual

Metodologia

1.2. Panorama da questão urbanística no Brasil

\section{Capítulo 2}

2.1. Direito de moradia

2.2 Direito à cidade e da cidade

2.3. Apresentação do caso referência: Rocinha

2.4. Regularização fundiária

\section{Capítulo 3}

3.1. O direito a propriedade e a interpretação flexível da norma

3.2. Situando o direito a partir da função social da propriedade e da Posse

3.3. A Questão da regularização fundiária e seus instrumentos jurídicos

\section{Capítulo 4}

4.1. A legitimidade da posse e a eficácia social do direito de moradia

4.2. A legitimidade da posse: processo de construção (histórico da Legitimação da Posse e a nova Lei)

4.3. Processo administrativo e etapas do procedimento

4.5. Obstáculos e Possibilidades para a tutela do direito de moradia

\section{Conclusão}

\section{Bibliografia}

Anexo 1 Auto de demarcação de região da favela da Rocinha

Anexo 2 Fotos da favela da Rocinha

Anexo 3 A Lei 11.977 de 2009

Anexo 4 Portaria CGJ RJ 207/2009

Anexo 5 Provimento 28/2004-CGJ RS 


\section{Capítulo 1}

Introdução

O presente trabalho versa sobre os institutos da posse e da propriedade, adotada a perspectiva do direito de moradia, hoje, com sentido mais amplo, pois vinculado ao direito à cidade. Propõe-se, assim, a partir do processo de regularização fundiária, privilegiando a legitimação de posse, uma discussão no âmbito da questão urgente para as áreas urbanas brasileiras.

Nesse contexto serão levantados assuntos como a favelização, a distribuição de renda e o planejamento urbano. O trabalho elege como fundamental a analise do instituto da Legitimação da Posse que recentemente com o advento da Lei 11.977 de 7 de julho de 2009 emerge como instrumento jurídico-urbanístico privilegiado de política da regularização fundiária das áreas urbanas.

A análise dos aludidos problemas urbanos urge ser feita sobre o prisma jurídico, em recorte com o direito a propriedade privada. O Brasil que se pretende um Estado Democrático de Direito não pode deixar a margem o direito de moradia, garantia constitucional que é.

Debruçar-se sobre a posse significa primordialmente estudar o direito à propriedade e como seu conteúdo vem sendo redefinido para atender a seus diversos fins.

Serão, portanto, pontos fundamentais o direito à cidade; a função social da cidade; o acesso a terra legal e urbanizada e as perspectivas para a redistribuição fundiária.

A Legitimação da Posse está consagrada hoje na legislação pátria e constitucionalmente fundamentada, portanto nesse trabalho procuramos contribuir para a compreensão do embasamento teórico de tal instrumento.

Discorrer sobre a função social da propriedade significa rediscutir o conceito ou significados que o direito a propriedade moderna admite, 
sobretudo, o entendimento que se tem a partir do código civil de 1916. É notório que uma perspectiva que coloca a referida garantia como direito individual e um "potestas" do proprietário faz remanescer entraves à aplicação e eficácia do novo paradigma de propriedade estabelecido na Constituição de 1988 como poder-dever e ainda direito difuso e essencial para a construção da cidadania.

Além disso, não se pode deixar de contextualizar a questão e apontar que a discussão se torna cada vez mais latente na cidade do Rio de Janeiro que reflete há muitos anos o espaço urbano deficitário quanto às necessidades de moradia da maior parte da população. Há que se pensar em como o Direito e os interpretes do direito podem democratizar a cidade.

O espaço urbano pode ser compreendido ${ }^{1}$, como aquele que reunindo meio ambiente natural e construído constrói uma paisagem única no Rio de Janeiro, onde estão cristalizadas as relações sociais e as lutas pelo direito à cidade.

Deve-se observar quão difícil é dar efetividade a função social da propriedade seja por fatores de ordem político econômica, seja por questões relativas ao direito processual. A própria estrutura do processo civil nas ações de usucapião denota os inúmeros entraves que se ligam à forma como se entendia o direito a propriedade. Neste sentido é salutar que se identifique a complexa relação entre os agentes e instituições na tutela do direito de propriedade, em via de regra, em detrimento do exercício do direito de moradia.

É de se lembrar que a legislação pátria consagra instrumentos de acesso à propriedade quais sejam o usucapião; usucapião especial urbano individual e coletivo, concessão de uso como direito real resolúvel; promessa de concessão de direito real de uso; concessão especial de uso para fins de moradia, entretanto o dilema de sua efetividade permanece.

\footnotetext{
${ }^{1}$ CAVALLAZZI, Rosangela Lunardelli e ARAÚJO, Eloísa Carvalho de. Revendo os papeis da ordem jurídica e urbanística na cidade do Rio de Janeiro. Artigo publicado na Revista Oculum. Rio de Janeiro: PROURB/PUCCAMP, 2003.
} 
Procuraremos, ainda, detalhar como foi o processo que estabeleceu a Legitimação da Posse na Lei 11.977 de 2009 e as dificuldades de sua aplicação e principalmente o desenrolar do procedimento administrativo que pode-se dizer a sua maior inovação.

Serão levantados alguns obstáculos para a aplicação dos instrumentos jurídicos e seus respectivos procedimentos a fim de reconhecer a titularidade a partir da posse e, em que medida, a Legitimação da Posse mostra-se inovadora para o fim que se propõe, qual seja o de conferir a população das favelas o acesso a terra regularizada propiciando o exercício do direito de moradia.

\section{Delimitação teórico conceitual}

Busca-se estudar o direito de propriedade privada à luz da função social e suas possibilidades de relação com o direito de moradia e de que modo o último informa e transforma o primeiro, dada a ótica constitucional.

Pretende-se traçar o que seria o senso comum teórico dos juristas ${ }^{2}$ no que tange a propriedade no recorte temporal que se coloca em virtude do Código Civil de 1916. Esta será a forma, o procedimento para avaliar as mudanças na concepção do direito de propriedade. Nota-se que tal recorte temporal é, por assim dizer, mais ligado a correntes de pensamento do que propriamente a um marco cronológico, consideramos que mais importante do que o tempo convencionado por datas é um tempo que se revela nos conceitos e nas formas de aplicar o Direito. O marco nesse sentido é o normativo traçado com o advento da legislação que preconiza a Legitimação da Posse como política urbana que se relaciona com o marco inegável da Constituição Democrática de 1988.

Assim se for privilegiada uma visão cronológica histórica, o objetivo da pesquisa irá perder-se. Deve-se notar que a sociedade atual revela-se um

\footnotetext{
${ }^{2}$ Warat introduz a categoria analítica "senso comum teórico dos juristas" como "a montagem de noções-representações - imagens - saberes, presentes nas práticas jurídicas, funcionando como um arsenal de ideologias práticas"; "um conjunto heterogêneo de hábitos semiológicos de referência." definindo "o horizonte a partir do qual se articulam as mensagens científicas." WARAT, L. A. Mitos e teorias na interpretação da lei. Porto Alegre: Síntese, 1979, p.19.
} 
emaranhado de antigas formas de pensar e agir com outras mais recentes. E exatamente nesse confronto de abordagens e entendimentos que o direito à propriedade deve ser visto.

\section{Metodologia}

A presente pesquisa apresenta uma dimensão interdisciplinar, pois em se tratando do mencionado assunto não há como se adotar linguagem positivista estanque e não se remeter à realidade fática. $\mathrm{O}$ que não significa desprestigiar esta ótica, pois, é essencial considerar que possivelmente a maior contribuição do instrumento Legitimação da Posse, seja exatamente, a possibilidade de contribuir para consagrar a propriedade por meio da posse, ou seja, a institucionalização das práticas sociais. O que se dizia, é que a realidade fática e histórica será alçada a uma importante posição, realidade essa que, para melhor ser conhecida necessita de uma abordagem interdisciplinar, logo, o necessário diálogo do urbanismo, planejamento urbano, sociologia urbana e história.

Neste sentido, adotamos o método do caso-referência ${ }^{3}$ para que se dê concretude à pesquisa e que seja possível aplicar e até mesmo confrontar o que foi pensado em primeira analise e que se possa, assim, aprimorar a conclusão.

Do ponto de vista do recorte temporal destaca-se como parâmetros o Código Civil de 1916, o novo Código Civil de 2002 informado pela Constituição e a Lei 11.977 de 7 de julho de 2009. Iremos delinear um sucinto panorama que evidencie as transformações a que passou a questão da moradia em nosso pais, tratando do Estatuto da Cidades Lei 10257 de 2001, que estabelece as diretrizes para a aplicação dos artigos 182 e 183 da

\footnotetext{
3 Segundo Rosângela Cavallazzi: "Trata-se de caso exemplar, presente na realidade (objeto real) que passa a constituir uma referência para a construção do objeto de conhecimento. $\mathrm{O}$ casoreferência permite a compreensão da análise da eficácia jurídica da norma pontualmente. O casoreferência pode ser adotado nas hipóteses em que a configuração do caso concreto não necessite do método do estudo de caso."

CAVALLAZZI. Rosângela Lunardelli. Métodos. Estudos sobre metodologia. Relatório de Pesquisa CNPq. 2009. PROURB/UFRJ. Rio de Janeiro.
} 
Constituição e que trata da Política Urbana, culminando com a análise da nova Lei 11.977.

\section{Panorama da questão urbanística no Brasil}

Propõe-se, neste momento, realizar uma breve contextualização para que se possa, enfim, enfrentar a questão da Legitimação da Posse como instrumento jurídico-urbanístico apto a possibilitar uma reforma urbana pautada na regularização fundiária das áreas de ocupação irregular. Assim, serão feitas algumas considerações acerca da questão urbana tanto em nível internacional quanto local. Nota-se que o enfoque será dado ao direito de moradia e será discutida a falta de acesso da população mais pobre à terra urbanizada.

Neste sentido, vale lembrar que em 2009 a população urbana ultrapassou a rural no mundo ${ }^{4}$ o que demonstra que, em geral, os países estão cada vez mais urbanizados, embora isso não necessariamente acarrete melhoria na qualidade de vida da população. No caso de nosso país $81 \%$ da população é urbana ${ }^{5}$, o que demonstra a importância de serem pensadas políticas urbanas no Brasil.

A ONU estima em 52 milhões o número de pessoas residentes em "aglomerados sub normais" no Brasil. ${ }^{6}$

Em relação ao déficit habitacional, moradias que precisariam ser construídas $^{7}$, no Brasil ele está situado na faixa entre 6 e 7 milhões de unidades, no Estado do Rio é em torno de 500 mil unidades, na região metropolitana é de 275 mil e na cidade do Rio de 200 mil unidades ${ }^{8}$.Porém, deve-se pontuar que o déficit habitacional não é privilégio apenas dos países em desenvolvimento, aparece, ainda que em menor escala, nos países desenvolvidos, tratando-se de um problema mundial.

\footnotetext{
${ }^{4}$ Fonte: Relatório anual de 2009 do Programa das Nações Unidas para assentamentos Humanos UN Habitat.

${ }^{5}$ Fonte IBGE.

${ }^{6}$ Fonte: Organização das Nações Unidas - Metas do Milênio

${ }^{7} \mathrm{O}$ déficit é composto fundamentalmente por famílias conviventes; com ônus excessivo de aluguel em seus orçamentos e residentes em moradias improvisadas, precárias e rústicas.

${ }^{8}$ Fonte: Ministério das Cidades.
} 
Ricardo Pereira Lira ${ }^{9}$ aponta dentre outras as seguintes causas como determinantes do adensamento demográfico e das formas irregulares encontradas pela população de baixa renda para exercer o seu direito de moradia:

“(...) a par do incremento vegetativo, que em alguns países, inclusive o nosso, não vem se elevando na mesma intensidade que outrora, ocorre um significativo aumento da população urbana, como conseqüência da industrialização; a inexistência de uma política urbana que enfrente a questão urbana de maneira planejada e consistente."

A taxa de urbanização brasileira foi exponencial: em 50 anos, de 1950 a 2000, nossas cidades receberam 120 milhões de pessoas, seja por fluxos migratórios, seja por crescimento vegetativo, eram 20 milhões nas cidades em 1950 e 138 milhões em 2000 ${ }^{10}$. Estas 120 milhões de pessoas, em termos gerais, correspondem à população da Inglaterra e da França juntas ${ }^{11}$.

A referida urbanização, posta no sentido de crescimento das cidades, não foi acompanhada de planejamento urbano ou investimentos em infraestrutura urbana condizentes com sua magnitude. Tão pouco foram implementadas políticas e programas habitacionais para as faixas de renda mais pobres, que disponibilizassem recursos e mecanismos financeiros adequados à esta população. Os reflexos de tal disparidade se fazem sentir hoje na paisagem urbana das diversas cidades brasileiras, com vastos territórios de informalidade e precariedade.

Vale destacar que a informalidade no que tange às construções não é exclusiva da população pobre. Há inúmeros exemplos de edificações e

\footnotetext{
${ }^{9}$ Lira, Ricardo Pereira. Direito Urbanístico, Estatuto da Cidade e Regularização fundiária. In: COUTINHO, Ronaldo e BONIZZATO, Luigi (Coord.). Direito á Cidade: Novas Concepções sobre as Relações Jurídicas no Espaço Social Urbano. Rio de Janeiro: Ed. Lumen Juris, 2007, pp 1 a 15.

${ }^{10}$ Fonte:IBGE

${ }^{11}$ Fonte: website official do Governo francês: www.elysee.fr e website www.royal.gov.uk
} 
construções de luxo implantadas em áreas de risco ou de proteção ambiental $^{12}$. Porém é a classe mais pobre que sofre com a precariedade.

Dados de $2005^{13}$ apontam que $50 \%$ das moradias construídas no Brasil naquele ano, ou seja, 600 mil unidades, o foram pelo mercado informal, portanto sem regularidade fundiária, sem financiamento, sem assessoria técnica, sem aprovação de projeto; esta proporção vem caindo em favor da produção formal nos últimos anos, todavia demonstra o passivo existente, e como ele foi sendo construído no vácuo de uma política habitacional eficaz.

No que se refere às favelas ${ }^{14}$ especificamente, nos anos 90 , no país, elas cresceram a taxas $2,5 \%$ maiores do que os bairros formais ${ }^{15}$. De acordo com o Ministério das Cidades, no Brasil, mais de 13 milhões de domicílios urbanos são irregulares, abrigando no mínimo $25 \%$ da população urbana.

No Rio de Janeiro, a partir dos dados do censo de 2000 do IBGE, entre 1,7 milhões e 2 milhões de pessoas vivem em favelas e loteamentos irregulares, em torno de 450 mil moradias, podendo se estimar portanto entre $29 \%$ e $34 \%$ da população nestas regiões. O quadro abaixo ${ }^{16}$ apresenta o crescimento populacional exclusivamente das favelas (sem os loteamentos irregulares), ao longo dos últimos 60 anos, demonstrando e sintetizando o que se apresentou nos parágrafos anteriores, qual seja, que a combinação de crescimento populacional vertiginoso, com a ausência de políticas de habitação compatíveis, o resultado é o crescimento das favelas e da irregularidade, solução encontrada pela população desamparada para solucionar um direito humano seu fundamental.

\footnotetext{
${ }^{12}$ MARICATO, Ermínia. As idéias fora do lugar e o lugar fora das idéias. In: Arantes, O. et. AL. A cidade do pensamento único. Petrópilos: Vozes, 2000.

13 ABRAMO, Pedro (org.). A Cidade da Informalidade. O desafio das cidades latino-americanas. Rio de Janeiro: Livraria Sette Letras, FAPERJ, 2003p.13a 21.

${ }^{14} \mathrm{O}$ conceito de favela, segundo o Ministério das Cidades, é o de aglomerado de domicílios autoconstruídos, dispostos de forma desordenada, geralmente denso e carente de serviços públicos essenciais, ocupando terreno de propriedade alheia seja este público ou particular.

${ }^{15}$ FONTE Ministério das Cidades

${ }^{16}$ Fonte IBGE e prefeitura do R.J.
} 


\begin{tabular}{|l|l|l|l|l|l|}
\hline & $\begin{array}{l}\text { População } \\
\text { em favelas }\end{array}$ & $\begin{array}{l}\text { População } \\
\text { da cidade }\end{array}$ & $\begin{array}{l}\% \text { da } \\
\text { população } \\
\text { em favelas }\end{array}$ & $\begin{array}{l}\text { Taxa de } \\
\text { crescimento } \\
\text { em favelas }\end{array}$ & $\begin{array}{l}\text { Taxa } \\
\text { crescimento } \\
\text { da cidade }\end{array}$ \\
\hline 1950 & 169.305 & 2.377 .451 & $7,24 \%$ & - & - \\
\hline 1960 & 337.412 & 3.281 .908 & $10,2 \%$ & $99,3 \%$ & $41,5 \%$ \\
\hline 1970 & 563.970 & 4.251 .918 & $13,26 \%$ & $67,1 \%$ & $28,6 \%$ \\
\hline 1980 & 628.170 & 5.090 .790 & $12,33 \%$ & $11,4 \%$ & $19,8 \%$ \\
\hline 1990 & 882.483 & 5.480 .778 & $16,10 \%$ & $40,5 \%$ & $7,6 \%$ \\
\hline 2000 & 1.092 .958 & 5.857 .335 & $18,66 \%$ & $23,9 \%$ & $6,9 \%$ \\
\hline
\end{tabular}

Fonte IBGE e prefeitura do R.J.

Salientamos, por fim, que o aumento da população não deve ser entendido como causa do déficit habitacional, mas sim a forma como foi e é conduzida a política urbana, marcada pela exclusão de certos segmentos sociais. Como dito, a questão reside não só na falha da política urbana em acompanhar o ritmo da urbanização, como na maneira como tal política foi distribuída no espaço urbano. 


\section{Capítulo 2}

\section{Direito de Moradia}

O direito de moradia é previsto em sede constitucional por força do Art. $6^{\mathbf{1} 17}$, enquadrando-se no rol dos direitos sociais. Segundo a lição de Paulo Bonavides ${ }^{18}$ os direitos sociais estão compreendidos na noção de Direitos Fundamentais. Nessa perspectiva, encontramos em Marco Aurélio Bezerra de Mello ${ }^{19}$ :

"os direitos fundamentais constituem normas jurídicas fundantes do estado democrático de direito que podem, no campo da concreção, surgir independentemente de um enunciado normativo, mas como será visto adiante, a completa proteção desse direito passa por um comportamento ativo do Poder Legislativo, no sentido de editar enunciados normativos que facilitem a regularização fundiária nas favelas e a Legitimação da Posse pode ser um caminho para tal desiderato."

Assim é que o direito de moradia faz parte do rol de direitos sociais e revela-se, portanto, um direito fundamental de segunda geração.

Neste sentido, embora o próprio fato da norma positiva se inserir no capitulo de direitos sociais da Constituição Federal já revele ser o direito de moradia um direito fundamental, o primordial é determinar o que, em última análise, significa direito fundamental na ordem jurídica, para que se entenda porque o direito de moradia é alçado a tal posição.

Normas de direito fundamental seriam aquelas que se ligam aos fundamentos do Estado, e, por conseguinte, em nossa sociedade, as que

\footnotetext{
${ }^{17}$ Art. $6^{\circ}$ da Constituição Federal com redação dada pela Emenda Constitucional no 26 de 2000: "Art. $6^{\circ}$ São direitos sociais a educação, a saúde, o trabalho, a moradia, o lazer, a segurança, a previdência social, a proteção à maternidade e à infância, a assistência aos desamparados, na forma desta Constituição."

${ }^{18}$ BONAVIDES, Paulo. Curso de Direito Constitucional. 17ed. São Paulo: Malheiros, 2005, p.56.

${ }_{19}$ MELO, Marco Aurélio Bezerra. Legitimação de Posse dos Imóveis Urbanos e o Direito de moradia. Rio de Janeiro: Ed. Lumen Juris, 2008. p. 35.
} 
fundam e contribuem para a formação do Estado Democrático de Direito. Enfrenta-se, porém, certa dificuldade para delimitá-las, no dizer de Marco Aurélio $^{20}$ :

"a segunda propugna que ser norma fundamental independe de seu locus no corpo da Constituição, pois normas de Direito fundamental são aquelas que dizem respeito aos fundamentos do Estado. $\mathrm{Na}$ experiência brasileira são aquelas que vivificam o estado democrático de direito."

Portanto, o mais importante é atinar para que as normas fundamentais não se esgotem nas que estão positivadas, pois dependem e se ligam à princípios e valores essenciais ao Estado Democrático de Direto. De qualquer forma, é de extrema valia que esteja o direito em tela previsto em sede Constitucional.

Verifica-se que o Direito de moradia foi incluído no rol de direitos sociais por força da emenda constitucional 26 de $2000^{21}$, o que se traduz em uma enorme conquista, embora, como dito, isto não signifique que antes do advento da referida emenda não pudesse ser considerado Direito Fundamental.

Desta feita, pode-se dizer que a escolha do legislador em definir determinado direito como direito fundamental o reveste de uma série de garantias. A título de exemplo:

“(...) são direitos subjetivos e assim outorgam aos titulares a possibilidade de impor os seus interesses em face dos órgãos obrigados (...)" 22

Assim sendo, a postura a ser adotada não só pelo Poder Legislativo como também pelo Judiciário e o Executivo, deve ser no sentido da transformação da realidade social de nossas cidades de forma a garantir o

\footnotetext{
${ }^{20}$ MELO, Marco Aurélio Bezerra. Legitimação de Posse dos Imóveis Urbanos e o Direito de moradia. Rio de Janeiro: Ed. Lumen Juris, 2008. p.38

21 Art. $6^{\circ}$ da Constituição Federal com redação dada pela Emenda Constitucional no 26 de 2000: "Art. $6^{\circ}$ São direitos sociais a educação, a saúde, o trabalho, a moradia, o lazer, a segurança, a previdência social, a proteção à maternidade e à infância, a assistência aos desamparados, na forma desta Constituição."

22 Gilmar Mendes Apud MELO, Marco Aurélio Bezerra. Legitimação de Posse dos Imóveis Urbanos e o Direito de moradia. Rio de Janeiro: Ed. Lumen Juris, 2008. 164 p.
} 
acesso à moradia formal da classe menos favorecida, o que, em certa medida, contribui para a prevenção de conflitos.

Importante distinção a ser feita no que diz respeito ao Direito de Moradia em relação aos direitos individuais é que o primeiro por se tratar de direito social depende de uma atuação do Estado que respeite os diferentes grupos sociais. De acordo com Daniel Almeida Oliveira ${ }^{23}$ :

\begin{abstract}
"Ao contrário dos direitos individuais, civis e políticos - positivista -normativista, que exige do Estado apenas que ele impeça a sua violação, seja por atividade ativa ou passiva - os direitos sociais não podem ser apenas positivados e dados aos cidadãos. Exige, ao revés, a implantação de vários programas e políticas públicas dirigidos a segmentos específicos da sociedade (seletividade inclusiva)."
\end{abstract}

Portanto a célebre lição de Rui Barbosa ${ }^{24}$ ao dizer "a regra de igualdade não consiste senão em quinhoar desigualmente aos desiguais, na medida em que se desigualam" deve ser apreendida e seguida.

Outra importante menção ao direito de moradia se faz por força do Art. 23, IX da Constituição Federal ${ }^{25}$, segundo o qual compete aos entes federativos promover programas para melhoria da infra-estrutura urbanística e construção de moradias.

Neste caso, entende-se que o termo competência que ali figura deve ser entendido, não somente como a possibilidade de realizar esforços para construir novas habitações e melhorar as já existentes, mas sim como incumbência, dever.

Assim é que, pautado no interesse coletivo, diante das desigualdades sociais que se manifestam no espaço urbano na forma de ocupações informais, deve o Estado promover o equilíbrio do atendimento

\footnotetext{
${ }^{23}$ OLIVEIRA, Daniel Almeida. O Direito da Cidade no Direito e nas Questões Sociais: Limites Possibilidades e Paradigmas. In: COUTINHO, Ronaldo e BONIZZATO, Luigi (Coord.). Direito á Cidade: Novas Concepções sobre as Relações Jurídicas no Espaço Social Urbano. Rio de Janeiro: Ed. Lumen Juris, 2007, p.89.

${ }^{24}$ BARBOSA, Rui. Oração aos moços. Rui Barbosa; edição popular anotada por Adriano da Gama Kury. - 5. ed. - Rio de Janeiro : Fundação Casa de Rui Barbosa, 1997.

25 "Art. 23. É competência comum da União, dos Estados, do Distrito Federal e dos Municípios:

$I X$ - promover programas de construção de moradias e a melhoria das condições habitacionais e de saneamento básico;"
} 
dos vários segmentos sociais. Neste sentido, em respeito ao princípio da isonomia, deve-se atender aos grupos mais vulneráveis e nisto reside o interesse público. Importante contribuição é a de José dos Santos Carvalho Filho $^{26}$ ao se debruçar sobre o Interesse Público:

"Deste modo, não é o indivíduo em si o destinatário da atividade administrativa, mas sim o grupo social como um todo. Saindo da era do individualismo exacerbado, o Estado passou a caracterizar-se como o Welfare State (Estado/bem-estar), dedicado a atender ao interesse público. Logicamente, as relações sociais vão ensejar, em determinados momentos, um conflito entre o interesse público e o privado, mas, ocorrendo esse conflito, há de prevalecer o interesse público.

No âmbito internacional o aludido direito é tutelado por uma série de Pactos e acordos Internacionais, coloca-se em relevo a Declaração Universal dos Direitos Humanos haja vista a sua importância e repercussão.

A Declaração Universal dos Direitos Humanos promulgada em 10 de dezembro de 1948 em seu Art. 25 lançou as bases da normatização internacional do Direito de moradia o que influenciou uma série de ordenamentos internos:

"toda pessoa tem direito a um nível de vida adequado que lhe assegure, assim como à sua família, a saúde e o bem estar, e de modo especial, a alimentação, o vestuário, a moradia, a assistência médica e os serviços sociais necessários(...)"

Por sua vez, o Pacto Internacional dos Direitos Econômicos, Sociais e Culturais, adotado e aberto à assinatura, ratificação e adesão pela Assembléia Geral das Nações Unidas em sua Resolução n²200 de 16 de dezembro de 1966 em seu Art. 11 assegura o direito de moradia, regulamentando o já declarado em 1948.

Posteriormente, a Segunda Conferência das Nações Unidas para assentamentos urbanos - Habitat II realizada em Istambul Turquia em 1956 previu em sua declaração:

${ }^{26}$ CARVAlHO FILHO, José dos Santos. Manual de Direito Administrativo. $21^{\text {a }}$ Edição.Rio de Janeiro: Lumen Júris, 2009.p.71 a 72. 
"Nós reafirmamos nosso compromisso com a plena e progressiva realização do direito de moradia adequada conforme providenciada pelos instrumentos internacionais"

É interessante observar que o direito de moradia consubstancia e possibilita o exercício de outros direitos, quais sejam: direito à privacidade; direito à segurança, à vida em família, é assim que o habitat é cogitado, no entender de Max $\mathrm{Neff}^{27}$, como um "satisfator" polivalente, que atende necessidades biológicas, emocionais e sociais permitindo gerar soluções para outros problemas comunitários e projetar uma realidade favorável para o desenvolvimento pessoal e coletivo.

Pelo exposto, o Direito de moradia é um direito difuso, atinente a todos, que se funda nos princípios republicanos. E por assim dizer, a tutela deste direito se liga de forma estreita ao princípio da dignidade da pessoa humana e da equidade, pois constitui direito de todos os cidadãos morar, residir em local digno, local este que propicie o exercício da cidadania, a vida em família, a privacidade, a saúde, dentre outros direitos. Assim sendo, é direito de todos possuir habitação, o que contribui para a diminuição das desigualdades sociais, conforme sintetiza Ricardo Pereira Lira: ${ }^{28}$

"Atendimento efetivo do direito de moradia digna e saudável para todos, como expressão mínima de cidadania, o que aliás decorre dos princípios republicanos fundamentais, consagrando a dignidade da pessoa humana, a erradicação da pobreza, da marginalização e da redução das desigualdades sociais, promovendo-se o bem de todos, sem preconceitos de raça, sexo, cor, idade e quaisquer outras formas de descriminação".

O que é corroborado por Bethania Alfonsin: ${ }^{29}$

"Assim trabalhar para diminuir o déficit habitacional brasileiro significa trabalhar para que os moradores de assentamentos autoproduzidos obtenham segurança no direito de morar, tenham qualidade de vida e de habitabilidade nesses locais."

\footnotetext{
${ }^{27}$ MAX-NEEF, M. et al. Desarrollo a escala humana. Montevideo: Nordan- Comunidad, 1993.

${ }^{28}$ LIRA, Ricardo Pereira. Direito Urbanístico, Estatuto da Cidade e Regularização fundiária. In: COUTINHO, Ronaldo e BONIZZATO, Luigi (Coord.). Direito á Cidade: Novas Concepções sobre as Relações Jurídicas no Espaço Social Urbano. Rio de Janeiro: Ed. Lumen Juris, 2007, p. 11.

${ }^{29}$ ALFONSIN, Betânia de Moraes. Direito de moradia: Instrumentos e experiências de regularização fundiárias nas cidades brasileiras. Rio de Janeiro: Observatório de Políticas Urbanas: IPPUR: FASE, 1997, p.22.
} 
O direito à cidade e da cidade

$\mathrm{O}$ direito à cidade pode ser vislumbrado como o direito a todos os cidadãos de forma isonômica de fazer parte da comunidade citadina usufruindo do espaço urbano, que deve assim propiciar acesso à moradia, a circulação que contará com redes de transporte, lazer, segurança, saúde, trabalho. Em suma, é na cidade que os diversos grupos sociais interagem, cabendo ao Estado facilitar o acesso de todos a estes bens e oportunidades.

Rosângela Lunardelli Cavallazzi ${ }^{30}$ ao conceituar o direito à cidade, como o núcleo essencial do Direito Urbanístico, ensina que este deve ser entendido como:

"expressão do direito à dignidade da pessoa humana, constitui o núcleo de um sistema composto por um feixe de direitos, incluindo o direito de moradia - implícita a regularização fundiária -, à educação, ao trabalho, à saúde, aos serviços públicos - implícito o saneamento -, ao lazer, à segurança, ao transporte público, a preservação do patrimônio cultural, histórico e paisagístico, ao meio ambiente natural e construído equilibrado - implícita a garantia do direito à cidades sustentáveis, entre muitos outros."

Segundo Nelson Saule Junior ${ }^{31}$ as cidades devem concretizar espaço social que propicie condições equitativas aos cidadãos, e ressalta que:

"A caminhada do direito à cidade com esta perspectiva vem desde as reflexões teóricas na década dos anos 60 do século XX formulada por Henri Lefebvre na França, até as construções das agendas políticas de reforma urbana por segmentos da sociedade civil em países da America Latina nos anos 80 (...)

Segundo Henri Lefebvre ${ }^{32}$ será, considerado o responsável pela disseminação da expressão Direito à cidade, a estruturação do espaço urbano se dá por escolhas pautadas pelo aspecto econômico:

\footnotetext{
${ }^{30}$ CAVALLAZZI, Rôsangela Lunardelli. A Paisagem urbana como patrimônio e seus instrumentos de tutela. Relatório de Pesquisa entregue ao CNPq, 2003.

${ }^{31}$ SAULE JR.,Nelson $O$ Direito à Cidade como Resposta Estratégica à Exclusão Social è à Segregação Espacial. In: SAULE JUNIOR, Nelson e PRESTES, Vanêsca B.(Coord.). Revista Magister de Direito Ambiental e Urbanístico: Ed. Magister, 2008 p.7 a 43.

${ }^{32}$ LEFEBVRE, Henri. $O$ direito à cidade. 3. ed. São Paulo: Centauro Editora, 2004b. p. 74
} 
"A multiplicação e a complexificação das trocas no sentido amplo da palavra não podem continuar sem que existam locais e momentos privilegiados, sem que esses lugares e momentos de encontro se libertem das coações do mercado, sem que a lei do valor de troca seja dominada, sem que se modifiquem as relações que condicionam o lucro (...) A interpretação revolucionária, até o momento, não levou em consideração esses novos elementos. Não seria possível que definindo mais rigorosamente as relações entre a industrialização e a urbanização, na situação de crise, se contribuísse para a superação da contradição do continuísmo e do descontinuísmo absoluto, do evolucionismo reformista e da revolução total? Se se deseja superar o mercado, a lei do valor de troca, o dinheiro e o lucro, não será necessário definir o lugar dessa possibilidade: a sociedade urbana, a cidade como valor de uso?"

Sendo o Direito à cidade direito difuso, emerge como uma garantia que não possui titularidade especificamente definida, paradoxalmente, a dita titularidade pode ser definida, então, como "de todos". É desta forma impregnado pela noção de bem público.

Segundo o ensinamento de Nelson Saule Júnior ${ }^{33}$ o Direito à cidade compreende:

“direitos inerentes às pessoas que vivem nas cidades de ter condições dignas de vida, de exercitar plenamente a cidadania, de ampliar os direitos fundamentais (individuais, econômicos, sociais, políticos e ambientais), de participar da gestão da cidade, de viver em um ambiente ecologicamente equilibrado e sustentável."

É de se lembrar que o direito à cidade articula as várias funções da cidade, assim com a lição de Rosângela Lunardelli Cavallazi ${ }^{34}$, o estudo do direito à cidade deve ser costurado pelos campos do conhecimento do Direito e do Urbanismo, marcado pela interdisciplinaridade, construindo a epistemologia do Direito Urbanístico.

\footnotetext{
${ }^{33}$ SAULE JR.,Nelson O Direito à Cidade como Resposta Estratégica à Exclusão Social e à Segregação Espacial. In: SAULE JUNIOR, Nelson e PRESTES, Vanêsca B.(Coord.). Revista Magister de Direito Ambiental e Urbanístico: Ed. Magister, 2008 p.7 a 43.

${ }^{34}$ CAVALLAZZI, Rosangela Lunardelli. O Estatuto Epistemológico do Direito Urbanístico Brasileiro: Possibilidades e Obstáculos na Tutela do Direito à cidade. In: COUTINHO, Ronaldo e BONIZZATO, Luigi (Coord.). Direito á Cidade: Novas Concepções sobre as Relações Jurídicas no Espaço Social Urbano. Rio de Janeiro: Ed. Lumen Juris, 2007, p.54.
} 
Assim sendo, não basta garantir o direito de moradia individualmente, mas sim todos os direitos que compõe o direito à cidade, o que implica dentre outros princípios o de distribuir de forma mais igualitária a infra-estrutura e os equipamentos urbanos pela cidade.

Falar hoje no direito à cidade, implica em abordar o Estatuto da Cidade, Lei Federal no 10.257 de 10 de julho de 2001, que regulamenta instrumentos jurídico-urbanísticos relevantes no que tange à política urbana.

O papel do Estatuto da Cidade é de suma relevância no atendimento ao que denomina como funções sociais da cidade:

"O Estatuto da Cidade com seu papel definidor de diretriz para a eficácia social dos arts.182 e 183 da Constituição de 1988 ao reunir em um só documento normativo os múltiplos instrumentos jurídiconormativos para a realização das funções sociais da cidade gera um singular impacto simbólico (...) a sua influência no renascimento do debate, a nível nacional, sobre a regularização e informalidade no campo da moradia popular, a partir de possíveis políticas públicas a serem implantadas pelo Governo Federal, especialmente as novas perspectivas com a criação do Ministério das Cidades ${ }^{35}$."

A Constituição Federal em seu artigos 182 e 183 refere-se a política urbana determinando que as cidades devem traçar, em função de suas peculiaridades, a função social da propriedade pública e privada, segundo seu próprio contexto, através da implementação do seu Plano Diretor.

Por conseguinte será no Plano Diretor que se desenhará o planejamento urbano, e será na razão direta de sua efetividade que as funções sociais da cidade se realizarão. Este planejamento, na conjuntura atual das cidades, é realizado considerando o uso, a ocupação e ordenamento do solo já existente, ou seja, não há uma cidade ideal a ser planejada, e sim uma realidade complexa fruto da intervenção de diversos atores sociais. Assim sendo, o Plano Diretor buscará dar maior equilíbrio ao

\footnotetext{
${ }^{35}$ CAVALLAZZI, Rosangela Lunardelli. O Estatuto Epistemológico do Direito Urbanístico Brasileiro: Possibilidades e Obstáculos na Tutela do Direito à cidade. In: COUTINHO, Ronaldo e BONIZZATO, Luigi (Coord.). Direito á Cidade: Novas Concepções sobre as Relações Jurídicas no Espaço Social Urbano. Rio de Janeiro: Ed. Lumen Juris, 2007, p.54.
} 
espaço urbano. Neste passo, o conceito de gestão democrática das cidades deve ser vislumbrado como a participação da população e dos diferentes segmentos da sociedade na formulação do Plano Diretor, garantindo assim a sua legitimidade.

Certo é que o mediador dos referidos atores sociais será preponderantemente o Município, que com o advento da Constituição de 1988 foi alçado à posição autônoma como ente federativo. Isto não significa que a União e os Estados não tenham competência no que se refere a implantação de políticas públicas urbanas, o que se quer ressaltar é o papel de destaque assumido pelos Municípios quanto ao Plano Diretor.

Apesar deste contexto em que o direito de moradia e à cidade estarem consagrados nacional e internacionalmente, a população de baixa renda vê-se impossibilitada de fazer parte da cidade sem acesso à aquisição formal de título de propriedade, e assim, busca espaços ociosos, sejam públicos ou privados, para exercitar o essencial direito de moradia. Os espaços ocupados são carentes de investimentos públicos, não dispondo de infra-estrutura considerável, assim é que são os próprios moradores que vão pouco a pouco e por seus meios equacionando esta carência, ainda que de forma precária.

É de se dizer que estão excluídos da cidade formal, e assim compromete-se a sua cidadania. É preciso incluir essas ocupações, esta paisagem urbana, na cidade reconhecida pelo Estado, o que se dará com a efetivação da regularização fundiária.

\section{Apresentação do caso referência: A Rocinha ${ }^{36}$}

A Rocinha está situada em uma das áreas de maior poder aquisitivo da zona sul da cidade do Rio de Janeiro. Possui cerca de 30 mil unidades habitacionais e uma população de mais de 100 mil habitantes estendendo-se por uma área de 100 hectares, com densidade de 1.000 habitantes por hectare. Desta forma conclui-se que apresenta a maior densidade dentro os

\footnotetext{
${ }^{36}$ Fonte: Banco de dados da Fundação Bento Rubião
} 
bairros da cidade, à frente, por exemplo, do bairro de Copacabana, que conta com aproximadamente 370 habitantes por hectare. Cumpre ressaltar que Copacabana em termos de organização urbanística compõe-se, basicamente de prédios residenciais, cuja tipologia privilegia a construção em altura com prédios de aproximadamente 12 andares.

A densidade da Rocinha possui como fatores a serem destacados a localização geográfica da favela, a proximidade com oportunidades de emprego e a história peculiar.

A origem da comunidade se deu com um somatório de loteamentos irregulares, diferentemente de uma ocupação classicamente enquadrada como favela. Isto porque a concepção mais usual de favela remete a uma ocupação feita por pessoas em terras antes registradas em nome de proprietários que as abandonaram. No caso em tela, antigos proprietários legalizados foram vendendo parte de sua propriedade, sem que, no entanto, fosse feita a respectiva regularização junto ao poder público, ocasionando, desta forma a falta de regularização das vendas nos cartórios de Registros Imobiliários. Nota-se, ainda, que estes compradores, por sua vez, desmembraram seus lotes seja para família ou para venda, o que também se deu de forma irregular, já que como dito já havia sido feito um primeiro parcelamento não registrado.

Foi assim que a Antiga Fazenda Quebra Cangalha foi sendo subdividida em pequenas chácaras e depois em cada vez lotes menores. A informalidade de tal subdivisão, frise-se, se diferencia de uma situação de ilegalidade visto que a falta de regulação ou informalidade não tinha como fato gerador uma situação contrária ao ordenamento jurídico.

A situação que presenciamos hoje na Rocinha marcada pela falta de regulamentação urbanística e fundiária explicita ocupação do solo consolidada e ignorada pelo Poder Público. Neste passo, registre-se a adequada interpretação de Bethania Afonsin ${ }^{37}$ :

\footnotetext{
${ }^{37}$ ALFONSIN, Betânia de Moraes. O Estatuto da Cidade e a Construção de Cidades Sustentáveis, justas e democráticas. Disponível em http://www.geocities.yahoo.com.br.

Este paper foi originalmente apresentado ao 2o Congresso Brasileiro do Ministério Público de Meio Ambiente, realizado em Canela de 29 a 31 de agosto de 2001.
} 
"O mais cruel dessa dualidade de estatutos de cidadania conferidos aos moradores, de um lado, da cidade formal, e de outro, da cidade informal, é que esta última ocupa uma área seguramente maior que a ocupada pela cidade "legal"."

$\mathrm{O}$ que temos atualmente é uma ocupação do solo em que falta planejamento e implementação da infra-estrutura, necessariamente efetivada pelo poder público. A infraestrutura é resultado e implantada a partir das necessidades mais urgentes e, em suma, realizada pelos próprios moradores.

O panorama apresentado, porém não pode perder de vista que a região da Rocinha se mostra plural em suas características, sendo necessário fazer algumas pontuações visto que a regularização fundiária nesta área deve se dar de acordo com as peculiaridades dos múltiplos tipos de uso e ocupação do solo na área.

Um critério diferenciador que devemos nos ater é justamente o das formas de apropriação do solo que, em última análise se liga a diferentes aspectos sócio-econômicos. O Bairro Barcellos, à título de exemplo, possui razoável infra-estrutura se comparado aos demais locais, possui fácil acesso às vias e transporte. É possível que se encontre na dada região pessoas que dispõem de mais de uma área de terra e ainda edifícios com um único morador cujas unidades ou são em sua integralidade disponibilizadas para a locação.

Há bairros menores como a Macega em que, por seu turno, a maioria das unidades habitacionais foram erguidas de forma precária na maior parte das vezes com uso de pedaços de madeira, com devastadoras dificuldades de acesso e péssimas condições de salubridade.

Neste sentido, retomo o que foi dito, salientando que para cada uma dessas áreas é preciso traçar uma estratégia diferente de ação, nos planos jurídicos e urbanísticos que impulsione seus moradores a fazer parte do processo de regularização, vez que as diferenças são bem maiores do que as 
visíveis: as prioridades, as relações econômicas, o nível de risco de despejo, o tempo de ocupação, dentre outros são notadamente diversos entre si.

A rápida ocupação e a escassez de áreas planas na comunidade, exceção feita ao Bairro Barcelos, foi um forte incremento populacional, um dos grandes indutores do crescimento e da ocupação dos terrenos mais acidentados, a partir das décadas de 40 e 50, quando então se deram outros fracionamentos irregulares de glebas maiores. A predominância de uso na Rocinha é residencial com concentração de áreas comercias em algumas vias estruturantes do bairro, como a Via Apia e a Estrada da Gávea. Algumas áreas, como o Bairro Barcellos, constituem centralidades, agregando áreas comerciais, serviços como bancos e casas lotéricas, além de instituições como cultos diversos, escolas e creches.

Em certo sentido, é possível considerar a favela como um município, tanto no que diz respeito à sua população quanto à sua dinâmica urbana, com seus setores de serviços e comércio movimentando a economia local e fornecendo empregos em número expressivo a boa parte de seus moradores, uma vez que tanto o mercado formal quanto o informal constituem uma vasta rede de abastecimento interno. Uma cidade.

$\mathrm{O}$ crescimento do bairro extrapolou os limites das glebas originais. $\mathrm{O}$ adensamento e o crescimento se deram pela ocupação das áreas de encosta, algumas dentro de áreas de preservação, bem como e, principalmente, pelo aumento do número de pavimentos em todas as áreas indistintamente. Num certo sentido e, mais recentemente, pode-se dizer que a Rocinha cresce a taxas explosivas para dentro ${ }^{38}$.

Todos estes vetores de crescimento levaram a que sejam praticamente inexistentes hoje áreas livres no bairro, cuja dinâmica urbana parte do princípio da "compra e venda" das construções existentes, seja através de contratos diversos ou cessão de direitos, com a conseqüente ampliação das mesmas, ou ainda da venda de suas lajes, a partir das quais novas residências são erguidas.

\footnotetext{
${ }^{38}$ A favela da Rocinha cresce de forma acentuada horizontalmente, ou seja, é relativamente mínimo o seu crescimento em área se comparado às edificações que se acumulam umas sobre as outras.
} 
Outro aspecto a destacar, que também concorre para incentivar a espiral da informalidade, é o de que os conflitos entre o poder público na aprovação dos projetos de parcelamentos e loteamentos elaborados pelos proprietários das várias glebas existentes propiciaram, em parte, a ocupação informal, com a aquisição dessas porções de terreno por outros moradores, antes de ser realizado o processo de regularização urbanística por parte do poder público. A alegação da não conformidade do projeto de loteamento com as normas de uso e ocupação do solo da legislação vigente à época contribuiu, portanto, para a ocupação irregular, que se deu lentamente, mas direcionada de acordo com as plantas elaboradas para estes loteamentos. Há, portanto, uma responsabilidade inegável dos órgãos públicos nesse processo, tanto em nível de planejamento, como na elaboração da legislação, como, por fim, na ausência de fiscalização, responsabilidade esta raramente assumida, imputando-se a irregularidade exclusivamente à população, que a seu favor possui sem dúvida o exercício do direito universal à moradia.

\section{O processo de Regularização fundiária}

A constituição de 1988 preconiza a criação de um direito coletivo no planejamento urbano. O planejamento urbano instituído pelo Estatuto da Cidade, através dos planos diretores, imprime uma nova visão neste campo. Além de orientar o futuro crescimento das cidades, por instituir instrumentos de regularização fundiária, tenta superar problemas urbanos acumulados por décadas. Desta forma, a regularização fundiária deve, portanto, ser estudada como parte integrante do processo de planejamento e gestão urbana.

Regularização fundiária diz respeito à reforma urbana, porém há diversas formas de se definir até que ponto se estende tal reforma. Há as que apresentam conteúdo mais conciso e outras que ampliam o seu significado. Em alguns casos, somente regula o registro cartorário da propriedade ou domínio. Estudiosos do tema entendem que não há como 
dissociar a descrita reforma jurídica de uma política de urbanização. Há, por fim, os que salientam tratar-se de reforma jurídica, urbanística e ambiental. Se não, vejamos a interpretação de Bethania Alfonsin ${ }^{39}$ :

"Em alguns locais, a ênfase recai meramente na regularização jurídica dos lotes. Em outras cidades, na recuperação urbana do assentamento, através da urbanização da área. Em outras áreas observa-se ainda uma grande preocupação com a regularização urbanística dos assentamentos (...)"

Conclui-se ser a melhor alternativa articular as políticas descritas, quais sejam a reforma jurídica, urbanística e ambiental. Neste ponto, apresenta-se uma importante questão: deve-se começar adotando uma regularização urbanística para depois proceder a regularização jurídica, ou ainda a regularização jurídica é primordial fazendo-se seguir pelas demais. Por fim pergunta-se se seria possível articular concomitantemente tais políticas. Ricardo Pereira Lira ${ }^{40}$ entende que a política de urbanização deveria anteceder a titulação dos espaços, visto que a urbanização alteraria os contornos das áreas. Porém, apontamos outra questão, qual seja, como seria possível na perspectiva jurídica o poder público urbanizar áreas ainda não regularizadas.

Apesar de não se pretender adentrar nesta pesquisa na questão da realocação, cumpre observar que esta, segundo a previsão legal do Estatuto da Cidade, deve ocorrer apenas em casos excepcionais em que se verifique perigo (risco) aos moradores. Quanto à questão ambiental, muitas vezes ganha esta um vulto maior com o objetivo escuso de justificar a remoção. Porém, haja vista a necessidade de se sobpesar os princípios, temos que, em muitos casos, o direito de moradia, em áreas consolidadas, deve ser

\footnotetext{
39 ALFONSIN, Betânia de Moraes. Direito de moradia: Instrumentos e experiências de regularização fundiárias nas cidades brasileiras. Rio de Janeiro: Observatório de Políticas Urbanas: IPPUR: FASE, 1997, p.23.

${ }^{40}$ LIRA, Ricardo Pereira. Direito Urbanístico, Estatuto da Cidade e Regularização fundiária. In: COUTINHO, Ronaldo e BONIZZATO, Luigi (Coord.). Direito á Cidade: Novas Concepções sobre as Relações Jurídicas no Espaço Social Urbano. Rio de Janeiro: Ed. Lumen Juris, 2007, p.15.
} 
privilegiado, pois resta consagrado como direito fundamental em nossa Carta Magna.

Nota-se que a regularização fundiária pode atingir locais em que o domínio da terra seja pública ou privada e em casos em que a favela ou ocupação se estende em áreas consideráveis, não é raro encontra-se as duas situações. Mais adiante será visto como tal distinção demanda diferentes instrumentos de regularização.

Uma importante ressalva é a de que, na esmagadora maioria dos casos, tal ocupação se dá em terrenos públicos, praticamente abandonados, sem uso ou utilidade social ou ainda lotes particulares cuja dificuldade de se identificar o proprietário é marcante e evidentemente não há aproveitamento do solo.

Assinala Ronaldo Coutinho ${ }^{41}$ que a produção do espaço urbano é um processo histórico, aduzindo crítica à regularização fundiária e ao Estatuto da Cidade:

“essa produção do espaço é um processo histórico, e é precisamente por ignorarem as particularidades do processo de urbanização sob a hegemonia do capital, que (...) privilegiam a necessidade de estabelecer uma "ordem" para a apropriação do solo urbano, mediante a intervenção do Poder Público, escorada por "novos" instrumentos e institutos jurídicos e no planejamento urbanístico, a despeito da própria lógica que estrutura o modo de produção capitalista(...)"

A referida abordagem aponta para uma importante reflexão em que não se deve menosprezar a criação histórica do espaço urbano fruto de um complexo de relações sociais e reflexo do modelo econômico estabelecido. Para ele, a proposta de instaurar nova ordem através de uma postura ativa do Estado alicerçada em novos instrumentos jurídicos não se revela apta a enfrentar o quadro que se perfaz.

Porém, adotar tal perspectiva pode levar a um posicionamento por demais crítico ao reduzir a possibilidade de mudança social através da criação e aplicação das normas jurídicas legítimas. Até porque, neste caso,

\footnotetext{
${ }^{41}$ COUTINHO, Ronaldo. A Mitologia da Cidade Sustentável no Capitalismo. In: COUTINHO, Ronaldo e BONIZZATO, Luigi (Coord.). Direito á Cidade: Novas Concepções sobre as Relações Jurídicas no Espaço Social Urbano. Rio de Janeiro: Ed. Lumen Juris, 2007, p.19
} 
o Estado teria papel peculiar de mediador não propriamente regulando as relações jurídicas, mas a partir da realidade iria induzir relações jurídicas e sociais como salienta Daniel Almeida Oliveira ${ }^{42}$.

\footnotetext{
${ }^{42}$ OLIVEIRA, Daniel Almeida. O Direito da Cidade no Direito e nas Questões Sociais: Limites Possibilidades e Paradigmas. In: COUTINHO, Ronaldo e BONIZZATO, Luigi (Coord.). Direito á Cidade: Novas Concepções sobre as Relações Jurídicas no Espaço Social Urbano. Rio de Janeiro: Ed. Lumen Juris, 2007, p.72.
} 


\section{Capítulo 3}

\subsection{O Direito à propriedade e a interpretação flexível da norma}

Propõe-se neste capítulo apresentar algumas referências a respeito do direito à propriedade de bens imóveis, segundo doutrinadores brasileiros, visando demonstrar como o sentido desse instituto jurídico foi passando por um considerável processo de mudança, tendo sido fundamental a imposição da função social da propriedade pública e privada. Portanto, se faz necessário compreender os conceitos jurídicos segundo seu contexto histórico, ou seja, reconhecer a sua historicidade.

Parte considerável, para não dizer a totalidade, dos juristas admite que o significado de direito à propriedade renovou-se, devendo hoje ser considerado de forma democrática. É indispensável lembrar que a Constituição Federal de 1988 teve papel fundamental na mudança de paradigma no que concerne à propriedade.

Augusto Werneck ${ }^{43}$ refere-se a tal mudança de paradigma ao tratar do fenômeno da funcionalização dos direitos:

\footnotetext{
"esta nota introdutória revela em que circunstâncias surpreendentes, às vezes, se demonstra o fenômeno da funcionalização dos direitos, cuja aplicação mais notável foi, sem dúvida ao direito de propriedade".
}

Posteriormente, o autor refere-se ao que chama de historicidade do conceito de propriedade o que evidencia o seu caráter relativo.

Assim, é interessante que nos reportemos à obra de Marco Aurélio Bezerra de Mello ${ }^{44}$ :

\footnotetext{
${ }^{43}$ WERNECK, Augusto. Função social da Cidade. Plano Diretor e Favelas. A Regularização Setorial nas Comunidades Populares e a Gestão Democrática das Cidades. In: COUTINHO, Ronaldo e BONIZZATO, Luigi (Coord.). Direito á Cidade: Novas Concepções sobre as Relações Jurídicas no Espaço Social Urbano. Rio de Janeiro: Ed. Lumen Juris, 2007, pp 123 a 124.

${ }^{44}$ MELO, Marco Aurélio Bezerra. Legitimação de Posse dos Imóveis Urbanos e o Direito de moradia. Rio de Janeiro: Ed. Lumen Juris, 2008. p.164.
} 
“(...) no estudo da propriedade, bem como nas demais instituições jurídicas tradicionais, os significantes permanecem os mesmos, mas os significados se modificam com o tempo. $\mathrm{O}$ vocábulo "propriedade" sofreu profunda transformação na transição do Estado Liberal ao estado Social e deste para o Estado Democrático de Direito"

Temos como o marco legal, em nosso ordenamento jurídico, a Constituição Federal de 1988 que estabeleceu novo paradigma para o direito à propriedade, como evidencia Caio Mario da Silva Pereira ${ }^{45}$ :

“(...) reconhecendo embora o direito de propriedade, a ordem jurídica abandonou a passividade que guardava aos conflitos de interesses, e passou a intervir, séria e severamente, no propósito de promover o bem comum que é uma das finalidades da lei, e ainda assegurar a justa distribuição da propriedade com igual oportunidade para todos."

Melhin Chalhub ${ }^{46}$ sintetiza a mudança sofrida no significado do direito de propriedade da seguinte forma:

"de fato a propriedade vem perdendo sua configuração individualista, intensificando-se contemporaneamente a configuração de um conceito mais consentâneo com o interesse coletivo."

Haja vista a mencionada historicidade do conceito de propriedade buscaremos, então, demonstrar como o referido direito foi sofrendo limitações ao longo da história.

O Direito Romano, de acordo com Venosa ${ }^{47}$, considerava a propriedade de forma absoluta, sendo esta entendida como direito individual e perpétuo. Porém, há os que entendem que até mesmo em Roma a propriedade privada já era alvo de limitações. De acordo com Melhin Chalhub, apesar da propriedade no Direito Romano ser considerada direito ilimitado, já estavam presentes algumas limitações.

\footnotetext{
45 PEREIRA, Caio Mário da Silva. Instituições de Direito Civil. Vol. IV. Rio de Janeiro: Ed. Forense, 2005, pp.467.

${ }^{46}$ CHALHUB, Melhim. Curso de Direito Civil: Direitos Reais. Rio de Janeiro. Forense, 2003.p.74

${ }^{47}$ VENOSA, Silvio de Salvo. (org.). Novo Código Civil. Texto comparado. 2a edição. São Paulo: Atlas, 2002.
} 
Já na Idade Média, segundo Wald, a propriedade perde seu caráter unitário e exclusivista vez que os vassalos utilizavam e se instalavam sobre o terreno e coexistia a propriedade do soberano, do suserano e de vários vassalos superpostas sobre o mesmo objeto, desta forma, como esclarece Melhin Chalhub, havia o dominium directum ou eminente exercido pelo senhor e o dominium utile que era desempenhado pelo vassalo.

A Revolução Francesa retoma a concepção do período clássico romano, em que a propriedade era vista como direito absoluto, inviolável e sagrado, adotando a perspectiva individualista e unitária da propriedade. Assim, de acordo com Venosa, o Código de Napoleão adota, em certa medida, a concepção romana. Porém mesmo gozando de notável liberdade cumpre salientar que o art.544 deste código já previa a limitação legal. De qualquer forma, a concepção do direito de propriedade pautada no Código de Napoleão em que se permitia ao proprietário fazer uso de seu bem da forma mais absoluta, desde que não atentasse contra a lei, atualmente, mais do que nunca, está visivelmente comprometida.

$\mathrm{Na}$ sociedade industrial, o sentido social da propriedade toma forma e a imposição de deveres ao proprietário enfraquece, segundo Chalhoub, a concepção individualista do domínio. Venosa destaca que o individualismo extremado perde forca e, segundo o autor, o socialismo contribui para se pensar a propriedade baseada em sentido social.

Diante de tal histórico pode-se perceber como o conceito de propriedade foi sendo flexibilizado e hoje admite nova configuração, o que evidencia Caio Mario ${ }^{48}$ :

"A verdade é que a propriedade individual vigente em nossos dias, exprimindo-se embora em termos clássicos e usando a mesma terminologia não conserva, todavia, conteúdo idêntico ao de suas origens históricas. É certo que se reconheça ao dominus o poder sobre a coisa; é exato que o domínio enfeixa os mesmos atributos originários - ius utendi, fruendi et abutendi. Mas é inegável também que essas faculdades suportam evidentes restrições legais, tão freqüentes e severas que se vislumbra a criação de novas noções."

\footnotetext{
${ }^{48}$ PEREIRA, Caio Mario da Silva. Instituições de Direito Civil. Vol.IV. Rio de Janeiro: Forense, 2005 p.84.
} 
Assim sendo, passamos agora a destacar referências de alguns autores a respeito dos atributos ora mencionados do jus utendi, fruendi et abutendi, e demontrar como a mudança de paradigma no conceito de propriedade neles se faz sentir.

A doutrina nacional ao conceituar o direito à propriedade faz menção às suas faculdades formuladas pelo direito romano do jus utendi, jus fruendi, jus abutendi e refere-se ao direito de reaver a coisa, com base no direito de seqüela que configura a rei vindicatio. É recorrente também a menção à amplitude do direito a propriedade em relação aos demais direitos reais servindo de paradigma para o estudo destes.

O jus utendi se refere à faculdade do proprietário usar a coisa como lhe aprouver. A questão relevante para nós é que não são poucos os autores que defendem a concepção mais conservadora do direito á propriedade segundo a qual o não uso é forma de uso da propriedade, como, por exemplo, Venosa ${ }^{49}$ ao considerar que o uso incluiria o que chama de "conduta estática de manter a coisa em seu poder sem utilização dinâmica." Porém deve ser feita contundente critica a tal entendimento, pois o não uso vai de encontro à concepção de propriedade segundo a sua função social, como veremos.

Jus abutendi é entendido como o direito de dispor, alienar o bem, e seria para Venosa, o poder mais abrangente. A questão que se coloca é a de ser este um direito subjetivo do proprietário podendo se estender até mesmo a destruição da coisa. Melhim Namen Chaloub entende que o proprietário pode destruir a coisa desde que isto não se mostre contrario ao interesse social. No entanto, em se tratando de bem imóvel questiona-se se haveria hipótese em que seria possível destruir a coisa respeitando-se o bem social. Resta evidente, assim, na concepção contemporânea de direito à propriedade que a referida faculdade comporta limitação. Assim, no entender de Silvio Rodrigues, o jus abutendi não comportaria o abuso da coisa ou sua destruição gratuita e para o autor nem mesmo o Direito

\footnotetext{
${ }^{49}$ VENOSA, Silvio de Salvo.(org.) Direito Civil. Direitos Reais. Vol. 05, 2a ed.. São Paulo: Atlas, 2002.p. 161
} 
Romano admitia o uso anti-social do domínio. Venosa é partidário de tal visão ao prescrever que o jus abutendi não comporta o sentido de abusar tampouco o de destruir a coisa.

Segundo Wald a rei vindicatio faria parte da estrutura externa da propriedade, pois se debruça sobre a relação entre o proprietário e terceiros. Silvio Rodrigues aduz que seria a prerrogativa de reivindicar o bem de quem quer que injustamente o detenha. Cabe, neste momento reflexão quanto existência de limitação, na medida em que se decorrido lapso legal e presentes os requisitos da usucapião, ou de outra forma de aquisição da propriedade o antes proprietário perde os direito de reivindicar a coisa. Isto porque a posse fundada no intuito de permanecer como proprietário de forma mansa e pacifica, será possível diante do não uso do proprietário.

Além das descritas faculdades são citadas pelos estudiosos as seguintes características do domínio ${ }^{50}$ : exclusividade, perpetuidade; caráter absoluto; e o fato de ser oponível Erga Omnes ${ }^{51}$.

Wald ressalta que a exclusividade se fazia presente no Direito Romano, tendo sido deixada de lado na Era Medieval e posteriormente foi recuperada na Revolução Francesa.

A idéia de perpetuidade, a priori, pode ser vista como a impossibilidade de extinção ou fim do direito que exerce o proprietário sobre a coisa. No entanto, cabe ao proprietário a possibilidade de alienar o bem quando queira, razão pela qual voluntariamente deixa de exercer o domínio. Além disto, pode ser extinto o direito a propriedade por forca da lei, como ensina Silvio Rodrigues, a propriedade pode ser extinta pela vontade do dono com a alienação ou por disposição de lei o que se daria por perecimento ou usucapião. Para Wald a propriedade pode ser revogável ou resolúvel. Entende-se hoje haver outras formas legais que põe fim à perpetuidade da propriedade, notadamente a celebrada Legitimação da

\footnotetext{
${ }^{50}$ Cabe aqui uma ressalva sob pena de não se precisar os conceitos: domínio difere de propriedade, pois este seria o direito de propriedade que recai sobre coisas corpóreas. Desta forma, por aqui estar tratando de bens imóveis, notadamente corpóreos permite-se utilizar o conceito de domínio como sinônimo de propriedade.

${ }^{51}$ Segundo Wald se liga a noção de que no caso do direito de propriedade o sujeito passivo é indeterminado, podendo ser, assim oposto contra todos.
} 
Posse, e a usucapião, como se vera mais adiante. Porem, no entender de Venosa no caso de usucapião não ha que se falar em quebra da perpetuidade pois não teria sido o não uso do proprietário que acarretaria a extinção e sim a atitude ativa do usucapiente. Não se questiona que a ação do usucapiente põe fim no domínio, e neste ponto é interessante a contribuição do autor. $O$ que se coloca é que a referida ação tem como fundamento ou pressuposto a atitude passiva do proprietário, e assim, o não uso que compromete a utilidade do bem está, portanto, na raiz da questão.

Importante atenção deve ser dada a idéia do caráter absoluto da propriedade como a submissão da coisa a vontade do dono. Washinton de $\operatorname{Barros}^{52}$ ressalta esta característica quando aduz que "realmente, em certo sentido, o direito de propriedade é absoluto". Tal ótica porem não se mostra completa, pois como veremos a vontade do proprietário não e a única que incide sobre o bem. Assim é que o próprio autor, posteriormente quando versa sobre as restrições ao direito de propriedade, assume que este não mais se reveste do caráter absoluto e intangível. Interessante a ressalva feita por Wald ao dizer que o proprietário não pode exercer suas faculdades de qualquer maneira, de forma a abusar do direito, pois o exercício do direito está submetido às normas legais, direitos de terceiros e a função social. Portando segundo o autor o caráter absoluto diz respeito à questão de inexistir outro direito real sobre o mesmo objeto quando a propriedade é plena. Disto decorre que o domínio pode por forca da elasticidade a prerrogativa de ser limitado ou onerado.

A elasticidade diz respeito à capacidade do direito de propriedade deixar e voltar a ser pleno, leciona Wald que quando a propriedade perde a sua plenitude pode recuperá-la se deixarem de se fazer sentir os direitos reais existentes sobre a coisa.

Percebe-se, haja vista os diferentes contornos que as aludidas características e faculdades passam a refletir que o direito à propriedade é situado na história e, portanto, foi recebendo diferentes interpretações.

\footnotetext{
${ }^{52}$ MONTEIRO, Washington de Barros. Curso de Direito Civil .37a Ed.São Paulo: Saraiva, 2003. p.79.
} 
3.2. Situando o direito a partir da função social da propriedade e da Posse

Conclui-se deste breve histórico que a trajetória do instituto do domínio é acompanhada por crescentes limitações às suas faculdades, o que significa uma crescente redução dos direitos do proprietário. Diferentes são as classificações das referidas limitações. Há as restrições voluntarias, as quais não devemos nos ater, as legais dentre as quais podem ser destacadas, as constitucionais, administrativas entre outras. Importante, assim, salientar a idéia de abuso de direito.

Josserand $^{53}$ entende que os direitos subjetivos não são absolutos, tem um fim que os ultrapassa, são direitos-função e se a determinada função não for respeitada se estará diante do abuso de direito. Imbuído do mesmo espírito Léon Duguit ${ }^{54}$ vai alem e leciona que a propriedade mais do que um direito subjetivo essencialmente seria uma função social ao ver de Duguit a propriedade não é um direito subjetivo do proprietário, mas a função social do detentor da riqueza.

A Constituição alemã de Weimar de 1919 foi a primeira a prever a função social quando previu que o uso da propriedade deve servir do interesse da coletividade, já no Brasil a idéia está presente desde a Constituição de 1934, se manteve em 1946, mas foi a Constituição de 1967 que introduziu a expressão literal com o uso de termo "função social" que foi mantido em 1969.

Fizemos questão, no entanto, de destacar como marco legal a Constituição Federal de 1988, pois nesta a função social assumiu nova conotação deixando de figurar como limitação ao direito de propriedade e passando a informar o direito de propriedade como um todo, interferindo em seu conteúdo.

\footnotetext{
${ }^{53}$ WALD, Arnoldo. Curso de Direito Civil Brasileiro. Vol. III ga Ed. São Paulo: Revista dos Tribunais, 1993 p.108.

${ }^{54}$ WALD, Arnoldo. Curso de Direito Civil Brasileiro. Vol. III ga Ed. São Paulo: Revista dos Tribunais, 1993 p.108 a 109.
} 
Assim as limitações podem ser entendidas como decorrentes da função social, como salienta Melhim Namen Chaloub ao reconhecer logo no momento em que conceitua o direito de propriedade as suas limitações como fruto da função social. Porém a partir de 1988 a imposição da função social configura uma obrigação muito além da mera limitação do direito de propriedade em vigor durante a vigência do Código Civil de 1916.

Assim sendo a Lei Magna de 1988 consagrou um processo histórico que veio pouco a pouco trazendo novos significados ao conceito de propriedade. Porém, conforme reconhecemos ao iniciar o trabalho, também hoje não há uma única concepção de propriedade logo, nem todos os juristas entendem que a propriedade deve respeitar a sua função social.

Além da função social da propriedade devemos examinar a função social da posse, e para tal devemos vislumbrar a posse em uma maior amplitude.

Reduzir a posse unicamente a aspecto do direito de propriedade nos parece uma concepção um tanto rígida e limitada. Isto porque, apesar da proteção à posse poder ter suas raízes em uma proteção à propriedade, foi ganhando maior vulto, podendo ser vista com maior autonomia. $\mathrm{O}$ que se quer elucidar é que no momento em que o interesse coletivo ganha destaque, os conceitos devem ser repensados. Marco Aurélio Bezzerra de Mello ${ }^{55}$ coloca que:

"Essa perspectiva clássica e conservadora parece amesquinhar o direito possessório frente à situação objetiva proprietária. Contudo, na reconstrução do direito privado levada a efeito, a partir do movimento de constitucionalização dos institutos do direito na ótica da funcionalização, não se pode deixar de vislumbrar na posse uma função social autônoma e atrelada de modo indissolúvel aos direitos fundamentais à moradia(posse-moradia) e trabalho(posse-trabalho)."

Se, como dito, a posse ganha autonomia em relação à propriedade, forçoso é dizer que distingue-se a função social da primeira da função social da última.

\footnotetext{
${ }^{55}$ MELO, Marco Aurélio Bezerra. Legitimação de Posse dos Imóveis Urbanos e o Direito de moradia. Rio de Janeiro: Ed. Lumen Juris, 2008. p.59-60.
} 
Tema dos mais controvertidos e complexos de direito civil a posse foi estudada por grandes juristas. Hoje, pode se dizer que não mais se verifica a dicotomia entre a teoria subjetiva e objetiva, haja vista ter o ordenamento jurídico recepcionado aspectos das duas. Embora alguns entendam que tenha sido consagrada no direito pátrio a teoria objetiva de Ihering.

Segundo Savigny ${ }^{56}$ são elementos constitutivos da posse o corpus, elemento de cunho material, e o animus, elemento psíquico, de forma que o que a diferencia da simples detenção é justamente a intenção do possuidor. Pode, assim o possuidor agir com animus domini (como proprietario) ou ainda animus rem sibi habendi (vontade de possuí-la para si ).

Ihering $^{57}$ vai contrapor a teoria subjetiva, pois não acolhe a idéia de animus, ao entender que não é este passível de comprovação, se tornando muito difícil a sua aferição. A teoria objetiva, no entanto, não abole por completo a questão da vontade no estudo do instituto da posse, o que faz é relacionar tal elemento ao poder (corpus). Neste sentido, não dissocia o corpus do animus, aduzindo que o segundo encontra-se implícito no primeiro. No ver de Ihering, posuidor é aquele que age em face da coisa corpórea como se fosse o proprietário, pois a posse nada mais é do que a exteriorização da propriedade.Tal desdobramento da concepção objetiva deve ser apreciado com muito cuidado, já que pode ser considerado um tanto reducionista. Não devemos entender que a única razão de se tutelar a posse seja a possibilidade da mesma estar evidenciando o domínio. Isto porque a posse por si só encerra garantias. Isto fica evidente ao se tratar o

\footnotetext{
${ }^{56}$ RODRIGUES, Silvio. Direito Civil. Direito das Coisas. Vol. 05. 27ạ edição. São Paulo: Saraiva, 2002.p.17 a 21.

${ }^{57}$ RODRIGUES, Silvio. Direito Civil. Direito das Coisas. Vol. 05. 27ạ edição. São Paulo: Saraiva, 2002.p.17 a 21.
} 
usucapião, instituto jurídico através do qual se alcança o direito à propriedade fundado na posse.

Pode-se dizer que a posse tem como fundamento uma situação fática, a questão que se coloca, no entanto, é conquanto a sua natureza ser fato ou direito. Tanto Savigny e Jhering, concordaram que a posse tem cunho jurídico, para o primeiro a posse é ao mesmo tempo um direito e um fato, enquanto que para Jhering é um direito. De qualquer forma, é inegável a proteção que o legislador dá a posse, o que retomaremos ao tratar propriamente da Legitimação da Posse.

De qualquer modo, as controvérsias a respeito da conceituação da posse como fato ou direito não nos parece oportuna, visto que e inegavelmente protegida pelo ordenamento jurídico. 


\subsection{A Questão da Regularização fundiária e seus instrumentos jurídicos}

A Concessão de Uso Especial para Fins de Moradia (CUEM) é um direito garantido através da MP 2.220/ 01, estabelecida com a finalidade de regularizar assentamentos de baixa renda em áreas públicas. O princípio que a rege é a de que o tempo gera direitos, mesmo no caso de imóveis públicos.

Os requisitos para obtenção do título são a ocorrência de cinco anos de posse sobre terreno público urbano com dimensões de até $250 \mathrm{~m} 2$, sem oposição; a utilização do terreno apenas para fins de moradia e a condição do posseiro de não proprietário ou concessionário de outro imóvel urbano ou rural.

A Concessão de Uso Especial para Fins de Moradia é materializada através de um contrato gratuito entre o poder público e o ocupante da área, ou por uma sentença judicial, caso os moradores ou seus representantes legais tenham protocolado por via administrativa solicitação de reconhecimento do direito, e não tenham obtido resposta no prazo de um ano. Em ambos os casos, obtenção por via administrativa ou judicial, deverá o contrato ou a sentença ser levada a registro no cartório de registro de imóveis, para que assim o instituto tenha plena eficácia.

A concessão da CUEM não é, portanto, discricionária, podendo a mesma, uma vez outorgada, ser transferida por compra e venda, doação ou por direitos sucessórios, só sendo revogada casa haja alteração de uso, qual seja para fins de moradia.

Existe ainda a possibilidade da outorga do instrumento de forma coletiva, a Concessão de Uso Especial para Fins de Moradia Coletiva, alternativa a ser utilizada quando não for possível a delimitação individualizada das posses, vindo a Concessão a ser promulgada sob a forma de condomínio, em que cada possuidor terá direito a uma fração ideal. Esta fração poderá ser idêntica ou não, firmada em acordo coletivo 
por escrito, cujo documento comprobatório acompanhará o registro da concessão coletiva, podendo a qualquer tempo ser revista, desde que por maioria absoluta dos seus integrantes.

Há divergências quanto se deveria a CUEM ser aplicada a toda é qualquer posse nas condições assinaladas acima, com cinco anos de existência a qualquer tempo, havendo outros que interpretam a lei como permitindo o uso de tal instrumento apenas para aqueles que tenham cinco anos ou mais de posse quando da promulgação da lei em quatro de setembro de 2001.

Trata-se sem dúvida de um instrumento de grande valia, transportando para os imóveis públicos a possibilidade de regularização fundiária nas mesmas condições requeridas para as áreas privadas através do instrumento da usucapião especial urbana, sendo por esta razão que alguns se referem à CUEM como a "usucapião das áreas públicas".

A Concessão de Direito Real de Uso - CDRU é um direito real aplicável igualmente em áreas privadas quanto públicas, neste último caso discricionário e resolúvel da parte do ente público. A cessão pode ser em caráter gratuito ou oneroso, não sendo limitado seu uso ao habitacional, podendo se dar para fins de industrialização, comércio, cultivo da terra ou qualquer outra utilização de interesse social.

O direito real pode ser transferido através de instrumento público ou particular ou mesmo através de ato administrativo, devendo ser registrado no Cartório de Registro de Imóveis, podendo ser transferido entre vivos ou por causa mortis.

Por tratar-se de bem público, sua concessão irá requerer autorização legislativa, avaliação e licitação na modalidade de concorrência, podendo haver dispensa destes requisitos nos casos das concessões destinadas à habitação popular.

Pode ainda o instrumento ser utilizado como garantia real de contratos de financiamento habitacionais de interesse social, quando os mesmos se dão sob a terra objeto da Concessão. 
Sendo um instrumento mais frágil do que a CUEM por sua natureza discricionária e resolúvel, sempre que esta última não se apresentar factível, reveste-se a CDRU como a alternativa possível, mas ainda assim viabiliza o direito constitucional à moradia.

A Usucapião pode ser utilizada quando uma pessoa, uma família ou um grupo de pessoas ocupa como se dono fosse um imóvel particular na cidade ou no campo, por um determinado tempo, sem que haja contestação judicial, tempo este delimitado de forma diversa nas diferentes modalidades existentes do instrumento, como será visto a seguir. A partir do atendimento aos prazos legais de cada modalidade, bem como de seus requisitos específicos, poderá a propriedade ser requerida através de ação judicial, utilizando-se a modalidade de Usucapião pertinente.

Como assinalado, existem várias modalidades de Usucapião. Uma primeira modalidade firma o prazo de quinze anos de posse, dentre outros requisitos, para aquisição originária da propriedade, conforme estabelecido pelo artigo 1238 do código civil , esta forma não é utilizável em processos de regularização fundiária habitacional de interesse social.

Uma segunda possibilidade requer dez anos de posse para a aquisição da propriedade, e seus requisitos estão estabelecidos pelo parágrafo único do aludido artigo 1238, figurando dentre estes o da utilização como moradia habitual, ou a realização de obras ou serviços produtivos, constituindo-se por sua vez esta modalidade numa alternativa frequente em processos de regularização fundiária urbana de interesse social, sempre e quando os posseiros não atenderem a dois dos requisitos da modalidade da Usucapião Especial Urbano, quais sejam o de não possuírem outro imóvel e/ou de limitar-se a posse a uma metragem de até $250 \mathrm{~m} 2$.

Como instrumento de larga utilização nos processos de regularização fundiária de habitações de interesse social, figura a Usucapião Especial Urbana, estabelecido pelo Estatuto da Cidade, Lei No. 10.257 de 10 de julho de 2001, em sua Seção V. Note-se ainda a existência da Usucapião estabelecida no artigo 1240 do código civil, cuja finalidade é a da regularização fundiária para fins habitacionais em áreas rurais. 
A Usucapião Especial de Imóvel Urbano é utilizável por aquele que possuir como sua área ou edificação urbana de até $250 \mathrm{~m} 2$, por cinco anos, ininterruptamente e sem oposição, utilizando-a para sua moradia ou de sua família, adquirindo-lhe o domínio desde que não seja proprietário de outro imóvel urbano ou rural, conforme estabelece artigo $9^{\circ}$. do Estatuo da Cidade. O parágrafo $3^{\circ}$, deste artigo admite que o herdeiro legítimo continua de pleno direito, a posse de seu antecessor, quando esta é contínua. Uma importante inovação da lei se dá quando permite que uma área urbana, com mais de $250 \mathrm{~m} 2$, onde não é possível delimitar o terreno ocupado por cada posseiro individualmente, pode ser usucapida individualmente, artigo $10^{\circ}$.

A Usucapião Especial Coletiva de Imóvel Urbana, quando assim declarada em sentença judicial, se constituirá em título a ser levado a registro no Cartório de Registro de Imóveis, podendo ser conferida pelo juiz fração ideal igual a cada integrante da ação, independente das dimensões que cada possuidor ocupe, ou ainda estabelecidas frações ideais diferenciadas, neste caso requerendo-se acordo neste sentido firmado por escrito pelos possuidores.

Além dos descritos mecanismos cumpre lembrar que quando se trata de terras da União serão utilizados os seguintes instrumentos: aforamento; concessão de direito real de uso; cessão de uso; inscrição de ocupação ou ainda a própria alienação. 


\section{Capítulo 4}

\subsection{A legitimidade da posse e a eficácia social do direito de moradia}

Há segundo a doutrina duas formas de aquisição da propriedade, a aquisição originária e derivada. Sem a pretensão de abrir uma grande discussão sobre o tema, é relevante colocar que a aquisição da propriedade por meio da posse se enquadraria na primeira definição.

A posse latu sensu mansa e pacífica sem oposição faz surgir ao possuidor o direito de argüir a propriedade sobre o dado bem. O usucapião era até o advento da lei 11.977 de 2009 o meio de consolidar a posse de propriedade privada em titulo de propriedade, o que era feito por via judicial. Não obstante, como vimos, haja outros instrumentos de regularização fundiária aplicáveis à propriedade pública, quais sejam a concessão de uso como direito real resolúvel, promessa de concessão de direito real de uso, concessão especial de uso para fins de moradia e aforamento.

A legitimidade segundo sua etimologia estaria ligada de forma estreita à legalidade, porém enquanto conceitos jurídicos se diferenciam. A legitimidade, neste sentido, prescinde do legal, a legitimidade da posse antecede a criação da norma legal. O que se procura dizer é que a posse como forma de ocupação de áreas irregulares com o fim de uso para a moradia é legitima, pois como vimos encontra seu fundamento na Constituição Federal. A posse descrita é legitima independentemente da referida lei, cujo papel se destina a afirmar e possibilitar o exercício do direito de moradia. Há neste ponto, quem critique a adoção do termo Legitimação da Posse por entender que a posse enquanto direito e função social já traz consigo a legitimidade. $\mathrm{O}$ melhor seria, então, compreender essa designação não como oposição às demais posses, pois na essência todas as demais posses são legítimas, mas sim no sentido de distinguir a posse que é institucionalmente reconhecida no campo jurídico. 
Pelo exposto, pode se vislumbrar que o uso da expressão Legitimação da Posse aponta para o sentido de habilitar para o exercícios de certos atos ou o gozo de certos direitos preenchendo os requisitos legais, ou seja, tornar legítimo para todos os efeitos da lei.

O conceito de Legitimação da Posse não é novidade na doutrina jurídica nacional, mas o certo é que com o conceito normativo adotado pela Lei 11.177 se estabelece novo parâmetro de tutela do direito de moradia.

Assim se afirma porque a mesma amplia, constitui alternativa ao procedimento do usucapião que dificulta e posterga a outorga do direito de propriedade pois esbarra em processo judicial. Tanto a Legitimação da Posse quanto o usucapião constituem formas de aquisição da propriedade pela posse. Ademais muitos não rara é a utilização do termo usucapião administrativo para designar a Legitimação da Posse. Em que pese a proximidade finalística dos institutos, o procedimento adotado por cada um para reconhecer a posse e convertê-la em propriedade os diferencia.

O processo judicial das ações de usucapião especial urbano para a regularização fundiária se estende por muitos anos o que compromete a efetividade da usucapião enquanto mecanismo de tutela do direito de moradia. A raiz do problema pode ser entendida segundo Marco Aurélio Bezerra de Mello $^{58}$ pelo fato do procedimento da Ação de usucapião ter como contexto o marco legal do Código Civil de 1973:

"Se o rito da Ação de usucapião fora criado no âmbito de uma visão individual de proteção de interesses, isso acaba se refletindo na dificuldade de adequação dessa moldura dentro do contexto de uma favela."

A praxe das referidas Ações determina que haja a citação pessoal dos confinantes além da citação por edital dos interessados, se houver. A participação processual do Ministério Público, da Fazenda Federal,

58 MELO, Marco Aurélio Bezerra. Legitimação de Posse dos Imóveis Urbanos e o Direito de moradia. Rio de Janeiro: Ed. Lumen Juris, 2008.p.138 a 139. 
Estadual e Municipal é indispensável e verifica-se que a oitiva de cada um desses entes da federação contribui para a morosidade do procedimento, o que afronta o Art. $5^{\circ}$, LXXVIII da Constituição Federal que trata da celeridade processual. Ademais se requer a planta detalhada dos imóveis, o que incluiria não só os confinantes externos como internos.

4.2 A legitimidade da posse: processo de construção (histórico da Legitimação de posse e a nova lei)

Como dito a Legitimação de posse não é algo novo, para isso é necessário que se faça um pequeno panorama histórico das terras e suas titularidades no Brasil.

As terras brasileiras encontravam-se em domínio de Portugal antes da posse efetiva, isto porque juridicamente já pertenciam a Coroa Portuguesa. Em 1500 o que se deu foi a formalização da posse. Posteriormente, mostrou-se necessária a ocupação do território, para que não fosse a Coroa Portuguesa surpreendida com ocupação de outros reinos. É nesse contexto que se dá a concessão de sesmarias e de capitanias hereditárias. É Curioso ressaltar que a função social da propriedade faz-se primordial, pois cabia aos donatários cultivar a terra dentre outros deveres ou aforá-las ou arrendá-las. Assim teve inicio a privatização das terras públicas no Brasil, em que, por mais que no início o objetivo fosse assegurar o domínio português o que se verificou com as referidas concessões foi a formação dos latifúndios. A utilização desta forma de ocupação e uso do solo se revela contraria ao interesse público e marca a estrutura fundiária de nosso país.

O sistema de sesmarias teve fim em 1822 e a utilização da terra com o fim de povoamento e uso como moradia e trabalho passou a constituir forma de aquisição no que se convencionou chamar de Regime de posses. Pode-se dizer que neste momento a posse e a propriedade se aproximavam e pouco nítida era a sua diferenciação. Utilizava-se a posse originária para conseguir a titularidade das terras. Porém ao contrario do que possa parecer 
isto não resultou em uma possibilidade de acesso à terra a população, visto que apenas os mais influentes conseguiram adquirir a propriedade desta forma.

A Lei de Terras a Lei no 601 de 18/09/1850 tratava das terras devolutas, aquelas pertencentes ao Estado, à época do Império e significou profunda mudança na estrutura fundiária do Brasil. Instaurou o fim do regime de posses. As posses poderiam ser convertidas em propriedades por meio de compra e venda, revalidação de sesmarias que cumpriam os seus encargos e legitimação de posses em acordo com a sua função social.

A lei de terras muda o regime principal de aquisição da propriedade que antes era a posse e passa a ser prioritariamente o da compra e venda, mas ao fazer tal opção e privilegiar o regime da compra e venda não extingue o da posse e sim o coloca em segundo plano ao tutelar o modo de aquisição do mercado.

A lei de terras, é de se dizer, não vem, como pode aparentar, para privilegiar a aquisição pelo mercado, mas sim para impedir que os imigrantes adquirissem imediatamente a propriedade de terras o que inviabilizaria seu trabalho na lavoura cafeeira para os senhores de terra. Então, se traduziu na exclusão dos recém libertos da escravatura e dos trabalhadores imigrantes do acesso a propriedade.

A lei de Legitimação da Posse vai ampliar o espaço institucional do modo de aquisição originário à exemplo do usucapião, portanto é possível reconhecer que a partir da Lei 11.977 de 2009 o espaço institucional da aquisição da propriedade pela aquisição da compra e venda é restringido.

A nova Lei define a Legitimação da Posse em seu Art. 47, IV como sendo "ato do poder público destinado a conferir titulo de reconhecimento de posse de imóvel objeto de demarcação urbanística ${ }^{59}$, com a identificação do ocupante e do tempo e natureza da posse”. Porém, seu grande objetivo extrapola esta definição pois no Art. 60 do referido diploma estabelece que

\footnotetext{
${ }^{59} \mathrm{O}$ titulo de Legitimação de posse se consubstancia em direito do possuidor que cumpriu os requisitos do ART.59 PU da Lei 11977, ou seja, não sejam proprietários de outro imóvel seja este urbano ou rural, não tenham outro título de legitimação de posse ou ainda tenham usucapido outro imóvel urbano, e a área de ocupação não ultrapasse $250 \mathrm{~m} 2$.
} 
"sem prejuízo dos direitos decorrentes da posse exercida anteriormente, o detentor do titulo de Legitimação da Posse, apos cinco anos de seu registro, poderá requerer ao oficial de registro de imóveis a conversão desse titulo em registro de propriedade, tendo em vista a aquisição por usucapião nos termos do Art.183 da Constituição Federal". Assim sendo, o fim maior é a conversão em direito de propriedade.

É interessante observar que a referida lei foi antecedida da Medida Provisória n. 459, de 25 de março de 2009 que no que tange ao Capítulo de Regularização fundiária de Assentamentos Urbanos e mais especificamente da seção da Regularização fundiária de Interesse Social não foi alterada de forma substancial pela Lei 11.977 de 2009. Destacam-se algumas modificações, o Art. 50 da MP refere-se à regularização de assentamentos urbanos enquanto o Art. 46 da Lei prefere tratá-los como assentamentos irregulares. O Art. 51, III da MP entende que a demarcação urbanística deve se dar apenas em relação à imóveis de domínio privado, já a Lei inclui os imóveis de domínio público ( art. 47, III). A medida provisória em seu artigo 51, VIII ao versar sobre a regularização fundiária de interesse social aduz que pode se dar em áreas da União ao passo que a Lei inclui as áreas do Estado, Distrito Federal e Municípios na redação do Art. 47, VII, c. A lei em seu art. 54, II destaca o papel das Fundações, organizações sociais, organizações da sociedade civil de interesse público e outras associações enquanto agentes de promoção da regularização fundiária.

\subsection{Processo Administrativo e etapas do procedimento}

A adoção de processo administrativo para a Legitimação de posse revela-se sua grande inovação. A desjudicialização, porém, não deve ser entendida como afronta ao principio da inafastabilidade da jurisdição, mas como garantidor da efetividade de um direito fundamental.

O processo administrativo para concessão de título de posse e por fim de titulo de propriedade traçado na Lei 11.977 de 2009 compreende o 
projeto de regularização fundiária art. 50 a 54 e o auto de demarcação, previsto pelo art.56 da referida Lei.

O projeto de Regularização fundiária deve definir dentre outros as áreas ou lotes a serem regularizadas; eventuais edificações a serem realocadas, vias de circulações existentes ou projetadas e demais áreas de uso público e as medidas previstas para a adequação da infra-estrutura básica.

A exigência de tal projeto vem ao encontro do objetivo de não só reconhecer o direito de moradia como também o de que esta seja digna e de acordo com os padrões mínimos de habitabilidade.

Quanto ao auto de demarcação ${ }^{60}$ deverá conter planta e memorial descritivo da área com suas medidas perimetrais área total, confrontantes, numero de matricula ou transcrição e a indicação do proprietário, se houver, planta de sobreposição da área demarcada com a situação da área. O auto de demarcação urbanística é o documento pelo qual o poder público ou fundações, associações, organizações sociais ${ }^{61}$ após ter estudado a área e sua ocupação irá demarcar o Perímetro da área objeto de Legitimação da Posse, e então irá confrontar a dita área com as matrículas referentes ou transcrições ali existentes.

Embora pela leitura da lei possa parecer que o projeto de regularização fundiária ocorra antes do auto da demarcação, do ponto de vista do procedimento de registro, será o projeto averbado após o encaminhamento do auto e sua tramitação no RGI. Isto não significa que o

\footnotetext{
${ }^{60}$ Art. 56. (...)

$\S 1^{\circ} \mathrm{O}$ auto de demarcação urbanística deve ser instruído com:

I - planta e memorial descritivo da área a ser regularizada, nos quais constem suas medidas perimetrais, área total, confrontantes, coordenadas preferencialmente georreferenciadas dos vértices definidores de seus limites, bem como seu número de matrícula ou transcrição e a indicação do proprietário, se houver;

II - planta de sobreposição do imóvel demarcado com a situação da área constante no registro de imóveis; e

III - certidão da matrícula ou transcrição da área a ser regularizada, emitida pelo registro de imóveis, ou, diante de sua inexistência, das circunscrições imobiliárias anteriormente competentes.

61 Art. 50. A regularização fundiária poderá ser promovida pela União, pelos Estados, pelo Distrito Federal e pelos Municípios e também por:

I - seus beneficiários, individual ou coletivamente; e

II - cooperativas habitacionais, associações de moradores, fundações, organizações sociais, organizações da sociedade civil de interesse público ou outras associações civis que tenham por finalidade atividades nas áreas de desenvolvimento urbano ou regularização fundiária.
} 
plano urbanístico de que trata o plano de regularização fundiária, não possa ser estudado e pensado desde o inicio. O que se quer ressaltar é que o Cartório examinará o auto da demarcação e procederá a busca pelos proprietários e, somente depois se registrará o desenho urbanístico da área, o que permitirá a abertura das matrículas individualizadas, como detalharemos a seguir.

Após o encaminhamento do auto de demarcação ao RGI buscará se identificar os proprietários que a área possua através das matrículas e transcrições que se inserem no dado perímetro ${ }^{62}$.

Assim, tem início a citação dos proprietários, confrontantes e interessados, se houver, para que no prazo de 15 dias apresentem oposição. ${ }^{63}$ No entanto, se a citação pessoal não for vitoriosa, não tendo sido localizado o proprietário no dado endereço, será utilizada citação por edital. $^{64}$

No caso de impugnação, o poder publico será notificado para se manifestar no prazo de sessenta dias. Se não houver impugnação será procedida a averbação da demarcação, ou seja, da área inserida no dado perímetro.

Feita a averbação do auto da demarcação urbanística poderá ser recebido, conforme definido no art. 51, efetuando-se o registro do parcelamento nele contido. O parcelamento em linhas gerais pode ser entendido como a definição de diferentes usos, tais como público ou privado, nestes determinando as vias públicas, lotes residenciais ou institucionais como creches, praças e escolas, entre outros.

\footnotetext{
${ }^{62}$ Art. 57. Encaminhado o auto de demarcação urbanística ao registro de imóveis, o oficial deverá proceder às buscas para identificação do proprietário da área a ser regularizada e de matrículas ou transcrições que a tenham por objeto.

$63 \S 1^{\mathrm{o}}$ Realizadas as buscas, o oficial do registro de imóveis deverá notificar pessoalmente o proprietário da área e, por edital, os confrontantes e eventuais interessados para, querendo, apresentarem, no prazo de 15 (quinze) dias, impugnação à averbação da demarcação urbanística.

${ }^{64} \S 20$ Se o proprietário não for localizado nos endereços constantes do registro de imóveis ou naqueles fornecidos pelo poder público, a notificação do proprietário será realizada por edital.

§3o São requisitos para a notificação por edital:

I - resumo do auto de demarcação urbanística, com a descrição que permita a identificação da área a ser demarcada e seu desenho simplificado;

II - publicação do edital, no prazo máximo de 60 (sessenta) dias, uma vez pela imprensa oficial e uma vez em jornal de grande circulação local; e

III - determinação do prazo de 15 (quinze) dias para apresentação de impugnação à averbação da demarcação urbanística.
} 
Isto feito, procederá o ente público a partir de cadastro sócioeconômico realizado com todas as famílias emitir o titulo de posse a ser registrado nas matriculas resultantes do parcelamento averbado conforme descrevemos.

Por fim, durante cinco anos subsistirão concomitantente os registros propriedade e posse sobre a área objeto da demarcação, findo os quais poderá o possuidor argüir que se converta o citado titulo de posse em titulo de propriedade. ${ }^{65}$

Destaca-se importante inovação da Lei 11977 ao estabelecer prazo para a aquisição da propriedade por meio da posse a ter inicio quando do registro do titulo de Legitimação da Posse, diferentemente do processo judicial de usucapião que buscava comprovar a posse exercida e configurada, nos termos da lei, antes do ajuizamento da ação. Assim, ao comprovar-se a posse mansa e pacífica no transcorrer do próprio procedimento administrativo, dispensa-se a complexidade do procedimento judicial, como, por exemplo, a comprovação do tempo de posse, oitivas dos interessados e a participação do Ministério Público. Portanto, a sentença deixa de ser requisito para a atestação do domínio e a propriedade.

\subsection{Obstáculos e Possibilidades para a tutela do direito de moradia}

Uma vez descrito o procedimento administrativo da Legitimação de posse, devemos analisar quais seriam os obstáculos e possibilidades de aplicação e efetividade do instituto.

\footnotetext{
${ }^{65}$ Art. 60. Sem prejuízo dos direitos decorrentes da posse exercida anteriormente, o detentor do título de legitimação de posse, após 5 (cinco) anos de seu registro, poderá requerer ao oficial de registro de imóveis a conversão desse título em registro de propriedade, tendo em vista sua aquisição por usucapião, nos termos do art.183 da Constituição Federal.

$\S 1^{\circ}$ Para requerer a conversão prevista no caput, o adquirente deverá apresentar:

I - certidões do cartório distribuidor demonstrando a inexistência de ações em andamento que versem sobre a posse ou a propriedade do imóvel;

II - declaração de que não possui outro imóvel urbano ou rural;

III - declaração de que o imóvel é utilizado para sua moradia ou de sua família; e

IV - declaração de que não teve reconhecido anteriormente o direito à usucapião de imóveis em áreas urbanas.

$\S 2^{\circ}$ As certidões previstas no inciso $\mathrm{I}$ do $\S 1^{\circ}$ serão relativas à totalidade da área e serão fornecidas pelo poder público.
} 
Inicialmente, por tudo que foi dito, é dada a possibilidade de tornar eficaz a regularização fundiária das favelas por meio da Legitimação da Posse, visto que a usucapião judicial não vinha cumprindo tal fim, pois esbarrava em moroso e complexo procedimento judicial. Assim, resolveuse a grande dificuldade que se tinha no procedimento judicial de citar os proprietários, e mais: não há no processo administrativo a necessidade de oitiva dos entes federativos e do Ministério Público. Grande contribuição se dá também ao desafogar o poder judiciário, o que reduz até mesmo o gasto público. Ressalte-se que os procedimentos cartorários que culminam com o título de propriedade serão gratuitos. Além disto, procedimentos judiciais de usucapião, ainda que coletivos, não permitiriam o desenvolvimento de programas massivos de regularização fundiária municipais, o que se torna possível com o advento da Lei 11.977 de 2009.

Veremos agora outras contribuições e ainda obstáculos advindos da aplicação da Lei 11.977 de 2009.

Deve-se pontuar o fato da legitimação fazer parte de um programa de habitação e assim estar condicionado à vontade política de determinado programa de governo. Temos, assim, a possibilidade de sua aplicação ter início e, posteriormente, ser suspensa. Ao mesmo tempo, deve -se lembrar que a lei em seu Art. 54, II prescreve a atuação de outras entidades, que podem tomar a iniciativa de realizar o trabalho de campo, como por exemplo o cadastramento socioeconômico, levantamento topográfico, plano urbanístico, dentre outros, sendo que sua atuação é limitada, pois requer-se a participação da prefeitura no encaminhamento do auto de demarcação do auto para o Registro de Imóveis, e principalmente quem confere o titulo de legitimação de posse.

$\mathrm{O}$ fato da legitimidade da posse nos termos da lei depender do auto de demarcação e do projeto urbanístico abre a questão da possibilidade de ser esta argüida ou não individualmente. A usucapião, como vimos, apresenta a sua modalidade coletiva ou individual, ao passo que a legitimidade da posse figura na lei 11977 de 2009 apenas em sua feição coletiva. Desta feita, temos que a concessão da Legitimação da Posse é ato 
discricionário do poder público, não abarcando a possibilidade de ser pleiteada individualmente. E mais, é ato discricionário para atendimento coletivo, o que significa que o próprio poder público deve levá-lo a termo em escala.

Ademais, como já explicitado a Legitimação da Posse apresenta-se como alternativa ao usucapião coletivo e, assim, a princípio, não substituiria o uso de outros instrumentos. Importante questão diz respeito a possibilidade de ser utilizada em áreas públicas. A medida provisória 459 em seu Art.60 p. $4^{\circ}$ vedava a legitimação em áreas públicas, já a lei a admite, desde que atendidas as legislações específicas Art.56, III p.4 ${ }^{\mathrm{o} 66}$. Vêse assim que a Legitimação da Posse configura-se como mais uma alternativa para a Regularização fundiária em áreas públicas.

Porém, ainda que não se impeça a utilização da legitimação em áreas públicas, no caso de possuidores que atendam os requisitos da Concessão de uso especial para fins de moradia este pode revelar-se instrumento mais efetivo.

Fazemos a ressalva de que a lei não esclarece em que se converterá o título de legitimação de posse em áreas públicas após os cinco anos. Não se sabe se poderá ser convertido em propriedade, exatamente por tratarem-se de terras públicas.

Outra questão refere-se a possibilidade do titulo de legitimação de áreas públicas ou privadas ser dado como garantia de empréstimos. Há dois relevantes desdobramentos. O primeiro refere-se a construção jurídica do instrumento como garantia efetiva de empréstimos, por exemplo a hipoteca que recai sobre o direito de propriedade poder recair sobre a posse. O segundo, como será a aceitação pelo mercado do titulo de Legitimação da Posse como garantia.

Outra gama de aspectos relaciona-se à participação e adesão da população. A Legitimação da Posse, como examinamos, ao que tudo indica

\footnotetext{
${ }^{66}$ Art.56, III § 4o No que se refere a áreas de domínio da União, aplicar-se-á o disposto na Seção III-A do Decreto-L"ei no 9.760, de 5 de setembro de 1946, inserida pela Lei no 11.481 , de 31 de maio de 2007, e, nas áreas de domínio dos Estados, Distrito Federal ou Municípios, a sua respectiva legislação patrimonial.
} 
será mais célere do que os demais instrumentos, constituindo-se, assim, numa motivação para a adesão da população. A demora no processo desencorajava os moradores a buscar a tutela judicial do usucapião e isto muda com a utilização da Legitimação da Posse. Sendo assim, ao apresentar resultados em curto prazo, por exemplo, a entrega pública de um primeiro numero de títulos motivará os demais possuidores a se cadastrarem entregarem documentos.

Além da descrita motivação, tem-se como benefício para a população a interessante formulação que estabelece o art. 52, V ao conceder o titulo preferencialmente pra a mulher, rompendo, assim, práticas de discriminação contra as mulheres. Isto porque, nas favelas prepondera a União estável como forma de relacionamento conjugal e assim não há a obrigatoriedade do titulo apresentar o nome de ambos, o que representa risco de se expedir o mesmo somente em nome do homem.

Ainda no tocante à população deve-se lembrar que assentamentos irregulares de maior densidade possuem lotes com ocupação multifamiliar, e assim, quando for convalidada a posse em propriedade a última se dará sobre a forma de condomínio. Portanto, isto significará uma novidade para os hábitos culturais desta população, que, por exemplo, terá que elaborar e adotar convenções de condomínio.

Ao dar efetividade à regularização fundiária a Legitimidade da posse acaba por concretizar os benefícios da primeira, sejam estes econômicos, sociais, urbanísticos ou outros.

Grande papel da Legitimação de posse, assim, reside na titulação da propriedade dos antes possuidores, o que confere um endereço formal ao morador das áreas antes irregulares.

A titulação incrementa a economia da cidade, pois o imóvel passa a servir como uma garantia para o crédito e incentiva que os moradores invistam na melhoria de seu imóvel.

Temos ainda como conseqüência da Regularização a possibilidade da cobrança de impostos o que se mostra um benefício a todos os cidadãos da cidade. 
Do ponto de vista urbanístico a regularização jurídica possibilitará a formulação de uma legislação urbanística para a área, definido-se os gabaritos, usos, estabelecendo o zoneamento e o nome das ruas, por exemplo.

Ainda que incipiente, o uso da Legitimação da Posse como instrumento de regularização fundiária na Rocinha aponta para os obstáculos e possibilidades da sua aplicação nas demais áreas de ocupação irregular. Após termos feito uma pequena caracterização da Rocinha em Capítulo anterior retomaremos neste momento para abordar as perspectivas de aplicação da Legitimação da Posse.

Assim que foi promulgada a lei 11977 foi feita uma articulação de atores 67 visando implementar a referida lei em uma área da comunidade, qual seja as subáreas de Cachopa, Cachopinha, Dionéia, Pastor Almir, Vila Verde e Trampolin que envolve cerca de cinco mil famílias.

Em sequência, a Corregedoria do Tribunal de Justiça do Estado do Rio de Janeiro criou grupos de trabalho com a participação de tais atores, objetivando discutir e instituir as diretrizes e procedimentos para a aplicação da Lei no Estado do Rio de Janeiro.

Deste processo resultou a Portaria no 207/2009 que reúne os procedimentos orientadores da atuação dos cartórios de Registro de Imóveis que possuem papel de destaque na implementação da lei.

Um obstáculo à implementação da Lei a nível nacional seria a adoção de procedimentos conflitantes por Corregedorias de diferentes Estados da Federação. Uma alternativa a isto seria a adoção de Lei Federal que regulamentasse a Lei 11977 de forma a uniformizar a aplicação da Lei em todo território nacional.

Retomando a questão da Regularização fundiária na Rocinha, temos que dado o elevado numero de moradores com a posse de mais de uma unidades em que o possuidor reside em uma destas e aluga as demais, será

\footnotetext{
${ }^{67}$ Município, Ministério das Cidades, Secretaria de Habitação e Município de Rio de Janeiro, Defensoria Pública, Fundação Bento Rubião e a Associação Nacional dos Registradores a ANOREG.
} 
possível a adoção do procedimento de Legitimação da Posse apenas para a unidade em que o mesmo reside.

\section{Conclusão}

A presente pesquisa permitiu o desenvolvimento de vários temas a partir dos autores consultados na perspectiva da leitura critica da Lei 11.977 de 2009.

Dedicamos o primeiro capítulo à questão urbanística no Brasil quando foi evidenciado o crescimento das cidades sem a necessária implementação de infraestrutura urbana para todos os cidadãos. A população mais pobre, privada de condições dignas de moradia e infraestrutura urbana, ou seja, do direito à cidade, busca como alternativa a criação de espaços urbanos informais, como o caso da favela da Rocinha. A regularização fundiária, especialmente norteada pela nova Lei 11.977, impõe-se na agenda urbana de nosso pais como forma de reverter este quadro.

Foi possível constatar que o direito à propriedade deve ser informado por sua função social, assim sendo, o não uso pelos proprietários e o uso pelos possuidores para fins de moradia faz nascer a estes últimos a possibilidade de reconhecimento de sua posse legítima. Foram apresentados diversos instrumentos para converter a posse mansa e pacífica em propriedade, já adotados pelo direito brasileiro.

Dentre estes a Legitimação da Posse, recentemente incorporada ao elenco de instrumentos de regularização fundiária, possui papel relevante na efetivação do direito social à moradia. Isto porque seu procedimento foi pensado de forma a simplificar e agilizar as praticas já concebidas, notadamente a usucapião especial urbana, permitindo a eficácia social do direito de moradia como garantia pela Constituição de 1988.

Cumpre lembrar, que a Lei 11.977 de forma hábil e eficaz dispensa a comprovação da posse nos moldes da ação judicial de usucapião, o que não compromete o princípio do contraditório. Pois, como salientado no decorrer 
de nosso trabalho, a lei estabelece um marco para a contagem do prazo para a aquisição da propriedade por meio da posse. Este marco é o registro do titulo de Legitimação da Posse, nos termos do Art.60 do referido diploma legal. Conclui-se que embora possa ser perceptível apenas uma pequena mudança, na verdade, significa um ganho enorme em termos de celeridade. Pode-se deduzir, a princípio, que, tal Lei ao determinar como necessários cinco anos a partir do registro de legitimidade da posse estaria exigindo mais tempo ainda para conceder a posse daqueles que já haviam cumprido o prazo estabelecido, a maior das vezes inclusive não chegando a seu termo. Entretanto tal idéia cai por terra quando examinamos que as ações de usucapião se estendem por muito mais tempo. Portanto, foi possível comprovar que a Lei 11977 foi construída viabilizando várias possibilidades, buscando reverter em alguns casos, melhorar em outros ou ampliar as práticas vigentes como explicitamos ao tratar dos obstáculos e possibilidades para a aplicação da aludida norma legal.

Sendo assim, a nova lei contribui de forma inegável para a regularização fundiária o que possibilita aos moradores de áreas consideradas irregulares o gozo de um feixe de direitos a partir do direito de moradia. Destaca-se a redução das desigualdades sociais e integração da paisagem urbana, sempre respeitando as peculiaridades de cada espaço urbano. Como resultado importante temos não só a redistribuição de renda, mas verdadeira democratização, visto que é reconhecido à população o status de cidadão. Além disto, possibilita a regularização fundiária em seus diversos aspectos além da regularização jurídica, como por exemplo o incremento da estrutura urbana dessas áreas o que como se pode notar tem inicio no procedimento de elaboração do projeto urbano e do auto de demarcação .

Conclui-se, portanto, que apesar dos novos desafios de aplicação da nova lei 11977, a Legitimação de Posse traduz-se em solução singular na tutela do direito de moradia. Porém não custa lembrar que o uso de mecanismos legais tal qual o da Legitimação da Posse deve ser acompanhado de novas políticas urbanas pensadas para as ocupações 
consideradas irregulares. Seria um tanto quanto pretencioso supor que a inovação da Lei 11977 por si só conseguirá promover mudança na estrutura fundiária de nossas cidades que como se viu está inserida em processo histórico que remonta aos tempos de colonização portuguesa, destacando-se a Lei de Terras e que atualmente está condicionada às disputas do mercado capitalista.

Portanto, nosso trabalho buscou motivar a reflexão, segundo uma abordagem interdisciplinar, da Legitimação da Posse, ressaltando obstáculos e possibilidades no papel de um novo lugar para a eficácia social do direito de moradia. 


\section{Bibliografia}

ABRAMO, Pedro (org.). A Cidade da Informalidade. O desafio das cidades latino-americanas. Rio de Janeiro: Livraria Sette Letras, FAPERJ, 2003.327p.

ACSERALD, Henri (org.). A Duração das Cidades: sustentabilidade e risco nas políticas urbanas. Rio de Janeiro: DP \& A, 2001.436p.

AFONSO, Miguel Reis e LISO, Carlos Henrique. A Concessão de Direito Real de uso na Regularização fundiária. In FERNANDES, Edésio (coord.). Direito Urbanístico. Belo Horizonte: Del Rey, 1998, pp. 121 a 131.

ALFONSIN, Betânia de Moraes. O Estatuto da Cidade e a Construção de Cidades Sustentáveis, justas e democráticas. Disponível em http://www.geocities.yahoo.com.br.

ALFONSIN, Betânia de Moraes. O significado do Estatuto da Cidade para a regularização fundiária no Brasil. In RIBEIRO, Luiz César de Queiroz e CARDOSO, Adauto Lucio (org.). Reforma Urbana e Gestão Democrática promessas e desafios do Estatuto da Cidade. Rio de Janeiro: Revan: Fase, 2003, pp. 93 a 102.

ALFONSIN, Betânia de Moraes. Direito de moradia: Instrumentos e experiências de regularização fundiárias nas cidades brasileiras. Rio de Janeiro: Observatório de Políticas Urbanas: IPPUR: FASE, 1997, 248 p.

BALDEZ, Miguel Lanzellotti. Conselhos Populares e Usucapião Especial Urbano. Petrópolis: CDDH, 1991. 26 p.

BALDEZ, Miguel Lanzellotti. A Luta pela Terra Urbana. In RIBEIRO, Luiz César de Queiroz e CARDOSO, Adauto Lucio (org.). Reforma Urbana e Gestão Democrática promessas e desafios do Estatuto da Cidade. Rio de Janeiro: Revan: Fase, 2003, pp. 71 a 92.

BARBOSA, Rui. Oração aos moços. Rui Barbosa; edição popular anotada por Adriano da Gama Kury. - 5. ed. - Rio de Janeiro : Fundação Casa de Rui Barbosa, 1997.

BARROSO, Luís Roberto. O Direito Constitucional e a Efetividade de suas normas. Limites e possibilidades da Constituição Brasileira. Rio de Janeiro: Renovar, 2001.

BERCOVICCI, Gilberto. O Direito de Propriedade e a Constituição. Algumas Considerações Críticas. In Caderno de Direito. Piracicaba: Unimep, 2003.

BONAVIDES, Paulo. Curso de Direito Constitucional. 17ed. São Paulo: Malheiros, 2005, p.560.

BOURDIEU, Pierre. O Poder Simbólico. Rio de Janeiro: Bertrand Brasil, 2005. 
CARDOSO, Adauto Lúcio e RIBEIRO, Luiz Cesar de Queiroz. Dualização e Reestruturação Urbana - O caso do Rio de Janeiro. Rio de Janeiro: Observatório de Políticas Urbanas: IPPUR: FASE, 1996. 102 p.

CARVALHO, Amilton Bueno de. Direito Alternativo na Jurisprudência. São Paulo: Acadêmica, 1993.

CARVALHO FILHO, José dos Santos. Manual de Direito Administrativo. 21 Edição.Rio de Janeiro: Lumen Júris, 2009.1177p.

CAVALLAZZI, Rosângela Lunardelli. A plasticidade na teoria contratual. Rio de Janeiro, UFRJ, Faculdade de Direito, 1993.

- Contestado: espaço do camponês, tempo da propriedade privada. Florianópolis: Fundação Boiteux, 2003.

A Paisagem urbana como patrimônio e seus instrumentos de tutela. Relatório de Pesquisa entregue ao CNPq, 2003.

Urbanismo e direito: notas para uma abordagem interdisciplinar do espaço urbano. In MACHADO, Denise B. Pinheiro (org.). Anais do IV Seminário de História da Cidade e do Urbanismo. Vol. 02. Rio de Janeiro: UFRJ/PROURB, 1996.

.e ARAÚJO, Eloísa Carvalho de. Revendo os papeis da ordem jurídica e urbanística na cidade do Rio de Janeiro. Artigo publicado na Revista Oculum. Rio de Janeiro: PROURB/PUCCAMP, 2003.

.O Estatuto Epistemológico do Direito Urbanístico Brasileiro: Possibilidades e Obstáculos na Tutela do Direito à cidade. In: COUTINHO, Ronaldo e BONIZZATO, Luigi (Coord.). Direito á Cidade: Novas Concepções sobre as Relações Jurídicas no Espaço Social Urbano. Rio de Janeiro: Ed. Lumen Juris, 2007, pp 53 a 69.

.; ALFONSIN, Betânia e FERREIRA, Rodrigo. Tutela JurídicoUrbanística. Plano de Diretrizes. Consultoria realizada para a Fiocruz, Setor 1, Campus Jacarepaguá, 2005.

CAVALLAZZI. Rosângela Lunardelli. Métodos. Estudos sobre metodologia. Relatório de Pesquisa CNPq. 2009. PROURB/UFRJ. Rio de Janeiro.

CHAlHUB, Melhim. Curso de Direito Civil: Direitos Reais. Rio de Janeiro. Forense, 2003.329p.

COMPARATO, Fábio Konder. Direito e deveres fundamentais em matéria de propriedade. In Revista Centro de Estudos Judiciários. Brasília, n. 03, v. 01, 1997, pp. 92 a 97.

COUTINHO, Ronaldo. A Mitologia da Cidade Sustentável no Capitalismo. In: COUTINHO, Ronaldo e BONIZZATO, Luigi (Coord.). Direito á Cidade: Novas Concepções sobre as Relações Jurídicas no Espaço Social Urbano. Rio de Janeiro: Ed. Lumen Juris, 2007, pp 17 a 51. 
DALLARI, Adilson Abreu e FERRAZ, Sérgio. Estatuto da Cidade. Comentários à Lei Federal 10.257/2001. São Paulo: Malheiros, 2002.

DI PIETRO, Maria Sulvia Zanella. Direito Administrativo. São Paulo: Editora Atlas, 1990.

DINIZ, Maria Helena. Curso de Direito Civil Brasileiro. $4^{\circ}$ volume. São Paulo: Saraiva, 2002.

ENGELS, Friedrich. A Origem da Família, da propriedade privada e do Estado. $4^{\mathrm{a}}$ edição. Rio de Janeiro: Civilização Brasileira, 1978.

. A Questão da Habitação. Belo Horizonte: Aldeia Global, 1979.

Estudos e Pesquisas - Informação Demográfica n. 12. Ministério do Planejamento, Orçamento e Gestão. Instituto Brasileiro de Geografia e Estatística - IBGE. Diretoria de Pesquisas. Coordenação de População e Indicadores Sociais. Síntese de Indicadores Sociais 2003. Rio de Janeiro, 2004.

FALCÃO, Joaquim de Arruda (org.). Conflito de Direito de Propriedade. Invasões Urbanas. Rio de Janeiro: Forense, 1984.

FERNANDES, Edésio. Direito e Urbanismo: entre a "cidade legal" e a "cidade ilegal”. In FERNANDES, Edésio (org.). Direito Urbanístico. Belo Horizonte: Del Rey, 1998.

. Direito e Urbanização no Brasil. In FERNANDES, Edésio (org.). Direito Urbanístico. Belo Horizonte: Del Rey, 1998. 2001 .

Direito Urbanístico e Política Urbana no Brasil. Belo Horizonte: Del Rey,

Perspectivas para a renovação das políticas de legalização de favelas no Brasil. In ABRAMO, Pedro (org.). A Cidade da Informalidade. O desafio das cidades latino-americanas. Rio de Janeiro: Livraria Sette Letras, FAPERJ, 2003, pp. 139 a 172.

FIGUEIREDO, Lúcia Valle. Disciplina urbanística da propriedade. São Paulo: Ed. RT, 1990.

FONSECA, Maria Guadalupe Piragibe da. Notas Preliminares sobre o Método Sócio-Jurídico-Crítico. In Revista de Teoria Jurídica e Práticas Sociais. Volume I. Rio de Janeiro: Núcleo Interdisciplinar de Direito e Sociedade - NIDS, 1989.

FONTES, André R. C. Limitações Constitucionais ao Direito de Propriedade. In TEPEDINO, Gustavo (coord.). Problemas de Direito Civil-Constitucional. Rio de Janeiro: Renovar, 2000, pp. 435 a 456.

FREITAS, Jose Carlos de (coord.). Temas de Direito Urbanístico 2. São Paulo: Imprensa Oficial do Estado: Ministério Publico do Estado de São Paulo, 2000. 
GOMES, Orlando. Direitos Reais. $14^{\mathrm{a}}$ edição. Atualização e notas de Humberto Theodoro Jr. Rio de Janeiro: Revista Forense, 1999.

GRAU, Eros Roberto. A Ordem Econômica na Constituição de 1988. Interpretação e Crítica. São Paulo: Malheiros Editores, 2004.

HART, H. L. A. El Concepto de Derecho. Buenos Aires: Editorial Abeledo-Perrot S.A., 1963.

JARDIM, Zélia Leocádia da Trindade. Regulamentação da Política Urbana e Garantia do Direito à cidade. In: COUTINHO, Ronaldo e BONIZZATO, Luigi (Coord.). Direito á Cidade: Novas Concepções sobre as Relações Jurídicas no Espaço Social Urbano. Rio de Janeiro: Ed. Lumen Juris, 2007, pp 97 a 122.

KELSEN, Hans. Teoria Pura do Direito. $6^{\mathrm{a}}$ edição. São Paulo: Martins Fontes, 1998.

LARENZ, Karl. Metodologia da Ciência do Direito. Lisboa: Fundação Calouste Gulbekian, 1997.

LEFEBVRE, Henri. $O$ direito à cidade. 3. ed. São Paulo: Centauro Editora, 2004b. p.74

LIRA, Ricardo Pereira. A propriedade urbanística. Rio de Janeiro: Editora Forense, 1990.

. Direito de moradia, cidadania e o Estatuto da Cidade. In RTDC, Vol. 12, Outubro/ Dezembro 2002, pp. 259 a 291.

Elementos de Direito Urbanístico. Rio de Janeiro: Renovar, 1997.

Direito Urbanístico, Estatuto da Cidade e Regularização fundiária. In: COUTINHO, Ronaldo e BONIZZATO, Luigi (Coord.). Direito á Cidade: Novas Concepções sobre as Relações Jurídicas no Espaço Social Urbano. Rio de Janeiro: Ed. Lumen Juris, 2007, pp 1 a 15.

MARICATO, Ermínia. As idéias fora do lugar e o lugar fora das idéias. In: Arantes, O. et. AL. A cidade do pensamento único. Petrópilos: Vozes, 2000.

MATTEI, Ugo. Desenvolvimentos Institucionais do Direito de Propriedade. In RTDC, Vol. 06, Abril/ Junho de 2001, pp. 99 a 126.

MAX-NEEF, M. et al. Desarrollo a escala humana. Montevideo: NordanComunidad, 1993.

MEIRELLES, Hely Lopes. Direito Administrativo Brasileiro. São Paulo: Editora Malheiros, 2001.

MELO, Marco Aurélio Bezerra. Legitimação de Posse dos Imóveis Urbanos e o Direito de moradia. Rio de Janeiro: Ed. Lumen Juris, 2008. 164 p. 
MIRANDA, Pontes de. Tratado de Direito Privado. Parte Especial. Tomo XI. Rio de Janeiro: Ed. Borsoi, 1955.

MONTEIRO, Washington de Barros. Curso de Direito Civil . $37^{\mathrm{a}}$ Ed.São Paulo: Saraiva, 2003. 469p.

MOREIRA NETO, Diogo de Figueiredo. Curso de Direito Administrativo. Rio de Janeiro: Editora Forense, 1989.

Direito Urbanístico e limitações administrativas urbanísticas. In Revista de Informação Legislativa, ano 27, n. 107, 1990.

MUKAI, Toshio. Direito e legislação urbanística no Brasil. São Paulo: Editora Saraiva, 1988.

NERY JÚNIOR, Nélson e NERY, Rosa Maria de Andrade. Novo Código Civil e legislação extravagante anotada. São Paulo: Ed. Revista dos Tribunais, 2002.

OLIVEIRA, Daniel Almeida. O Direito da Cidade no Direito e nas Questões Sociais: Limites Possibilidades e Paradigmas. In: COUTINHO, Ronaldo e BONIZZATO, Luigi (Coord.). Direito á Cidade: Novas Concepções sobre as Relações Jurídicas no Espaço Social Urbano. Rio de Janeiro: Ed. Lumen Juris, 2007, pp 71 a 96.

OSÓRIO, Leticia Marques. Acesso à terra e legislação na América Latina.In: SAULE JUNIOR, Nelson (Coord.).Revista Magister de Direito Ambiental e Urbanístico. Porto Alegre: Ed.Magister, 2008.p.83-114.

PEREIRA, Caio Mário da Silva. Instituições de Direito Civil. Vol. IV. Rio de Janeiro: Ed. Forense, 2005, pp.467.

RIBEIRO, Luiz César de Queiroz e CARDOSO, Adauto Lucio (org.). Reforma Urbana e Gestão Democrática promessas e desafios do Estatuto da Cidade. Rio de Janeiro: Revan: Fase, 2003.

RODRIGUES, Silvio. Direito Civil. Direito das Coisas. Vol. 05. $27^{\mathrm{a}}$ edição. São Paulo: Saraiva, 2002.

SAULE JR., Nelson. A Proteção Jurídica da Moradia nos Assentamentos Irregulares. Porto Alegre: Sergio Antonio Fabris Editor, 2004.

SAULE JR.,Nelson $O$ Direito à Cidade como Resposta Estratégica à Exclusão Social e à Segregação Espacial. In: SAULE JUNIOR, Nelson e PRESTES, Vanêsca B.(Coord.). Revista Magister de Direito Ambiental e Urbanístico: Ed. Magister, 2008 p.7 a 43.

SILVA, Jose Afonso da. Curso de Direito Constitucional Positivo. São Paulo: Malheiros, 2000.

Direito Urbanístico Brasileiro. São Paulo: Ed. Revista dos Tribunais, 
SMOLKA, Martim O. Regularização da ocupação do solo urbano: a solução que é parte do problema, o problema que é parte da solução. In ABRAMO, Pedro (org.). A Cidade da Informalidade. $O$ desafio das cidades latino-americanas. Rio de Janeiro: Livraria

SUNDFELD, Carlos Ari. Função social da propriedade. In DALLARI, Adilson Abreu e FIGUEIREDO, Lucia Valle (coord.). Temas de Direito Urbanístico - 1. São Paulo: Ed. RT, 1987.

TEPEDINO, Gustavo (coord.). Problemas de Direito Civil-Constitucional. Rio de Janeiro: Renovar, 2000.

TORRES, Marcos Alcino de A. Instrumentos Urbanisticos e a Propriedade urbana imóvel (implicações e confronto por conta da função social da cidade e propriedade urbana). In TEPEDINO, Gustavo (coord.). Problemas de Direito Civil-Constitucional. Rio de Janeiro: Renovar, 2000, pp. 467 a 513.

VENOSA, Silvio de Salvo. (org.). Novo Código Civil. Texto comparado. $2^{\mathrm{a}}$ edição. São Paulo: Atlas, 2002.161p.

Direito Civil. Direitos Reais. Vol. 05, 2ª ed.. São Paulo: Atlas, 2002.

WALD, Arnoldo. Curso de Direito Civil Brasileiro. Vol. III $9^{\text {a }}$ Ed. São Paulo: Revista dos Tribunais, 1993 p.108 a 109.413p.

WARAT, L. A. Mitos e teorias na interpretação da lei. Porto Alegre: Síntese, 1979.261p.

WERNECK, Augusto. Função social da Cidade. Plano Diretor e Favelas. A Regularização Setorial nas Comunidades Populares e a Gestão Democrática das Cidades. In: COUTINHO, Ronaldo e BONIZZATO, Luigi (Coord.). Direito á Cidade: Novas Concepções sobre as Relações Jurídicas no Espaço Social Urbano. Rio de Janeiro: Ed. Lumen Juris, 2007, pp 123 a 142.

Pesquisa na Internet:

www.ibge.gov.br.

www.onu.org.

www.unhabitat.org

www.bentorubião.org.br

www.fase.org.br.

www.ministeriodascidade.gov.br

www.fundaçãojoaopinheiro.com.br

www.elysee.fr

www.royal.gov.uk

www.prefeiturarj.gov.br 
ANEXO 1 Auto de demarcação

Fonte: Banco de dados Fundação Bento Rubião

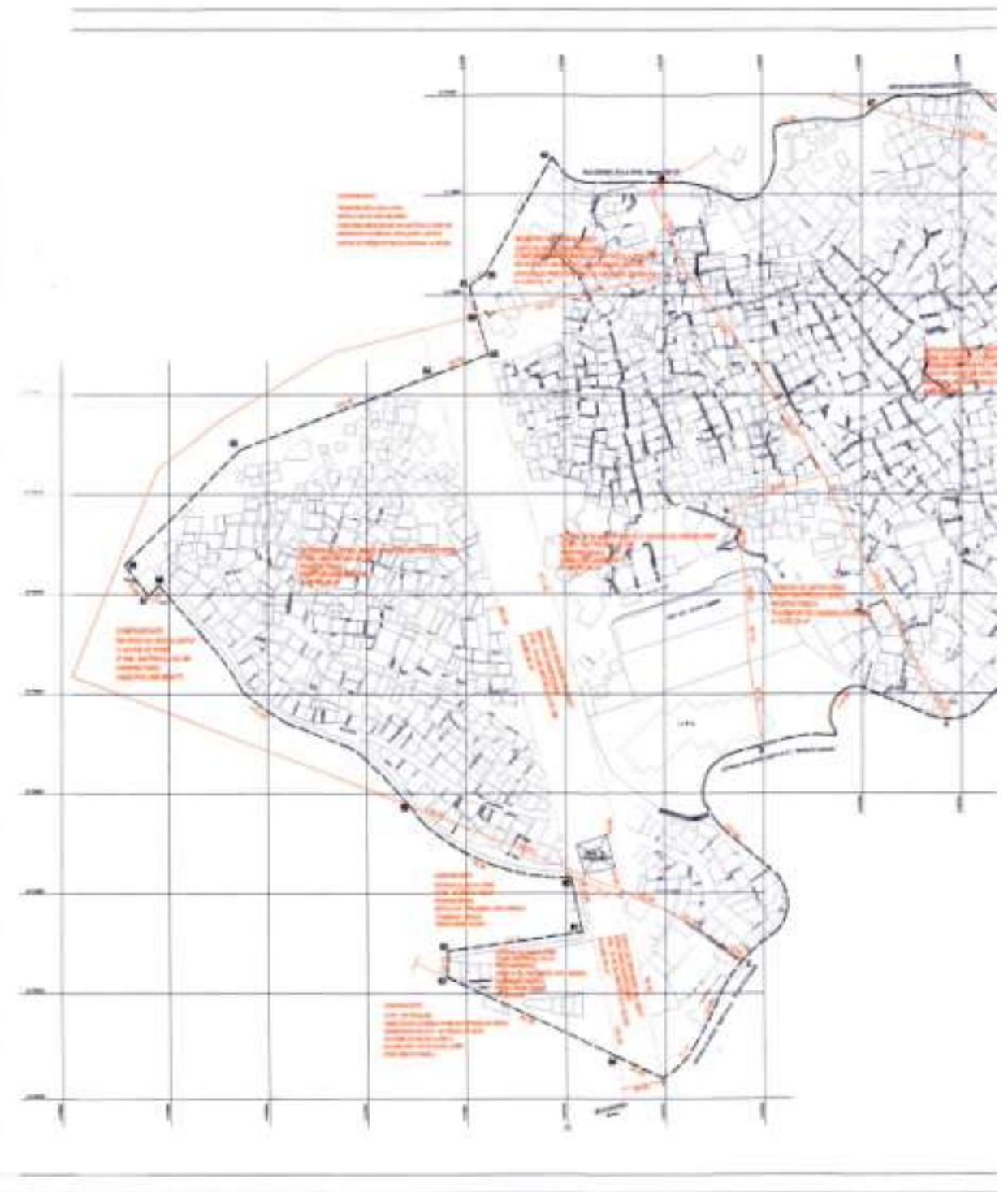




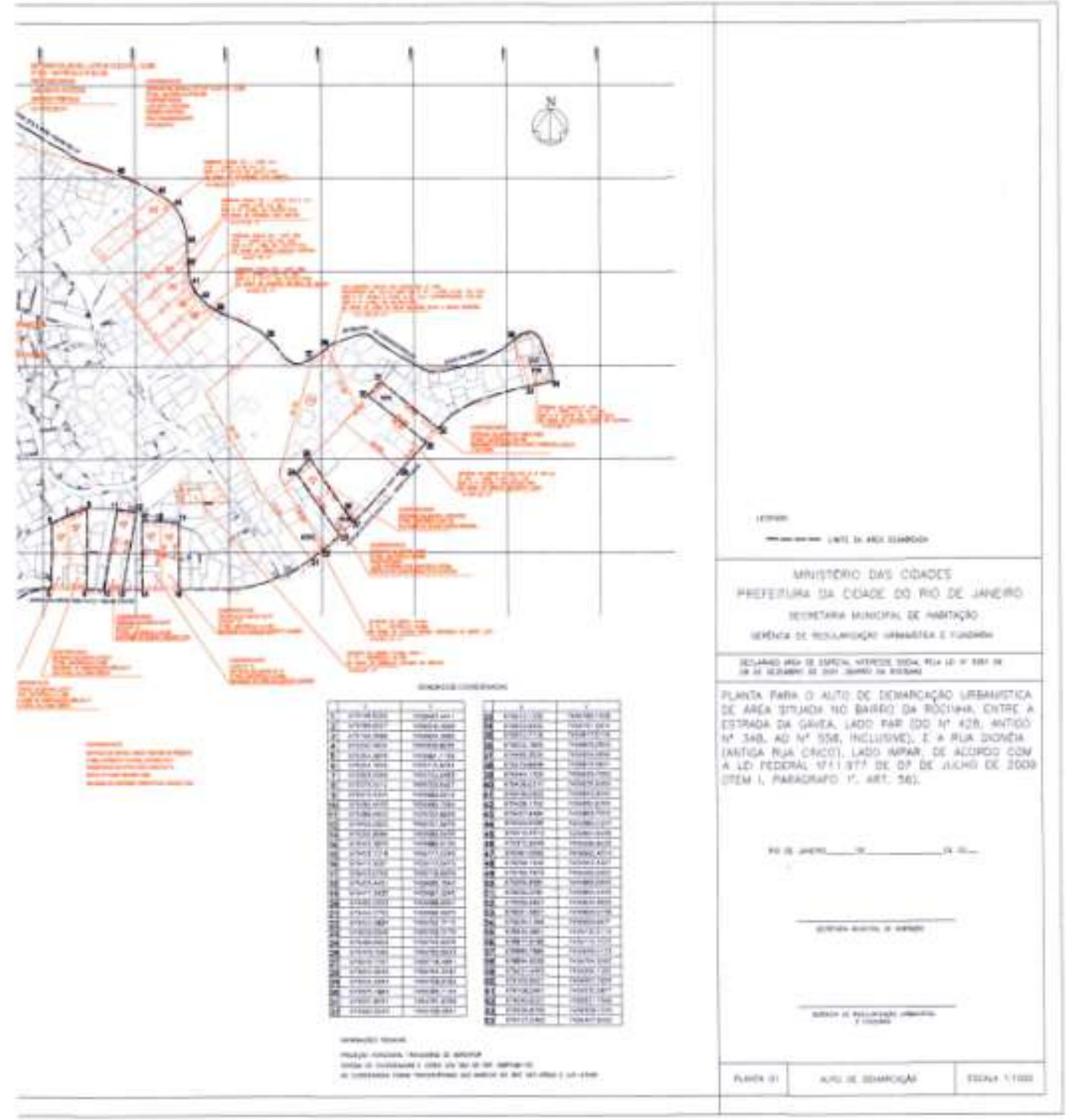




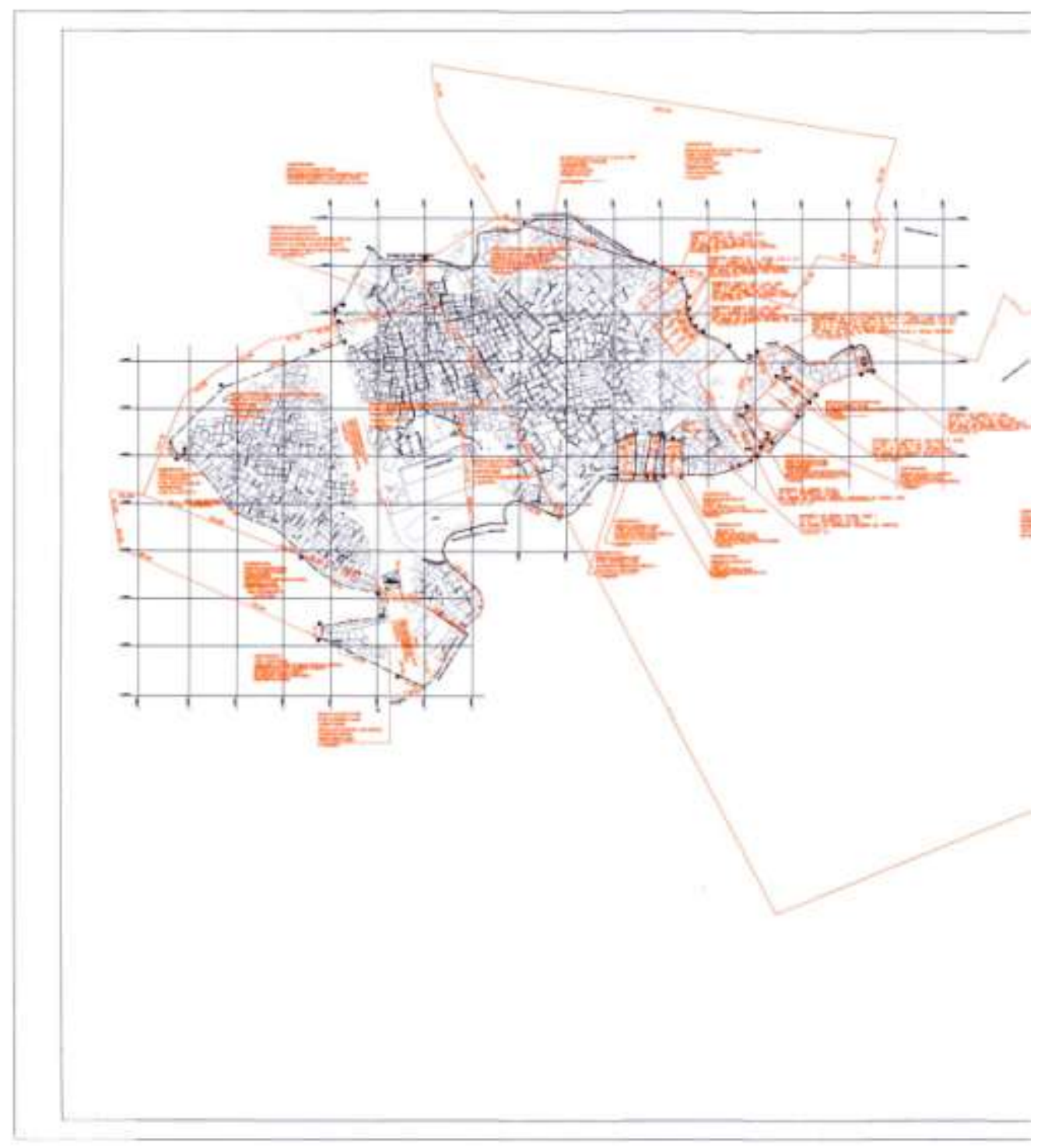




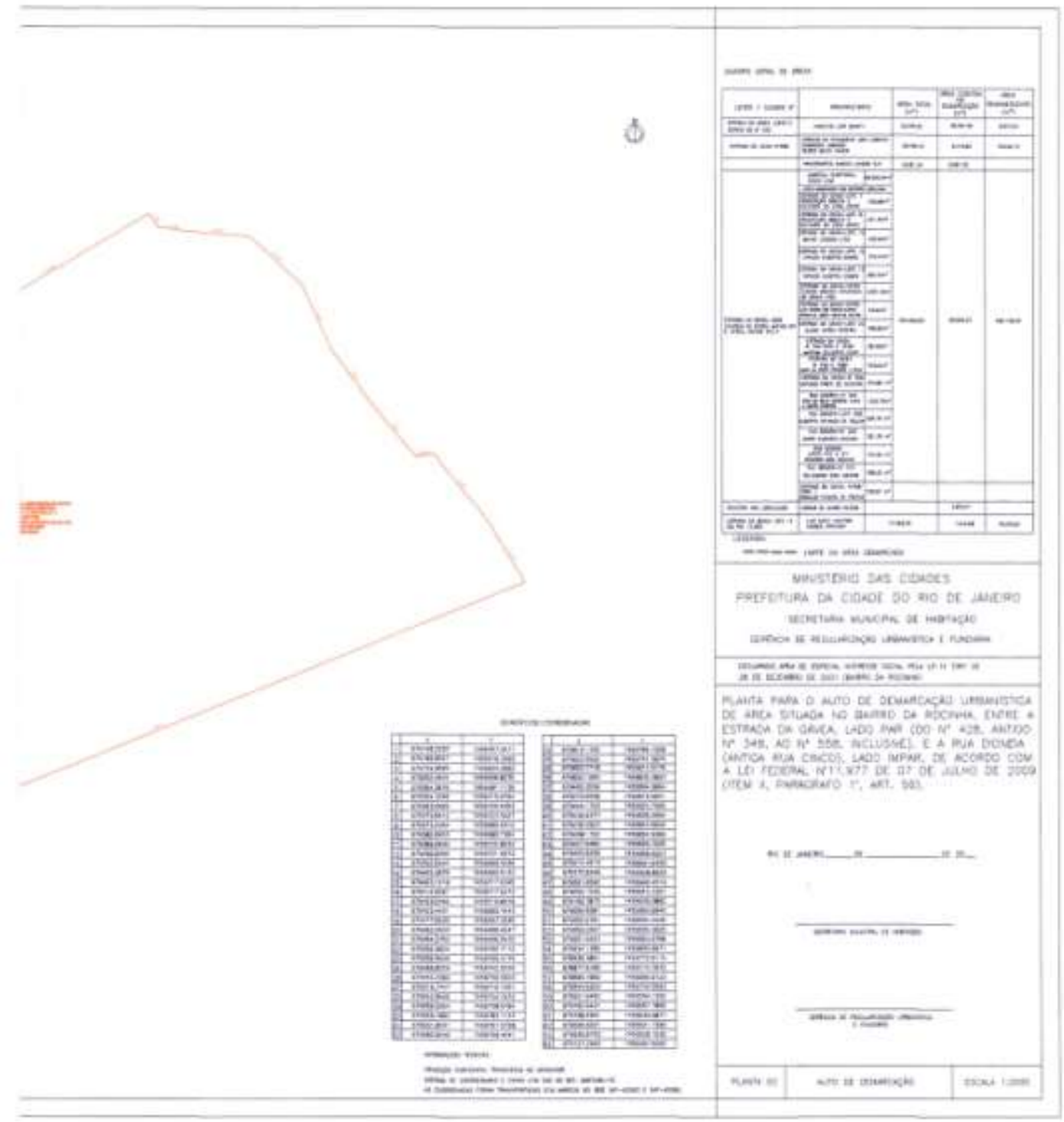


ANEXO 2 FOTOS DA ROCINHA

Fonte: Arquivo Fundação Bento Rubião

fotógrafo: Douglas Engle-Austral

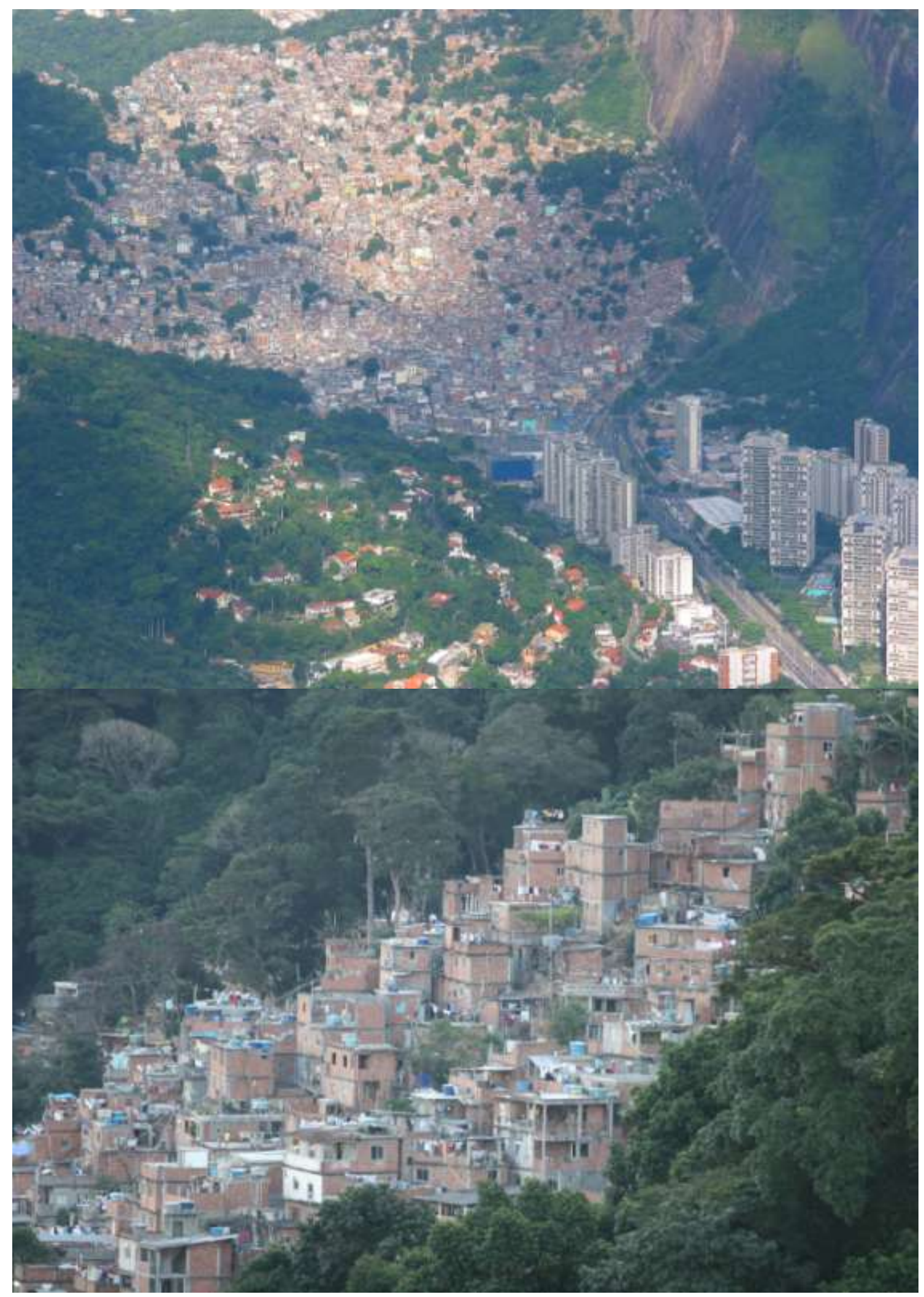




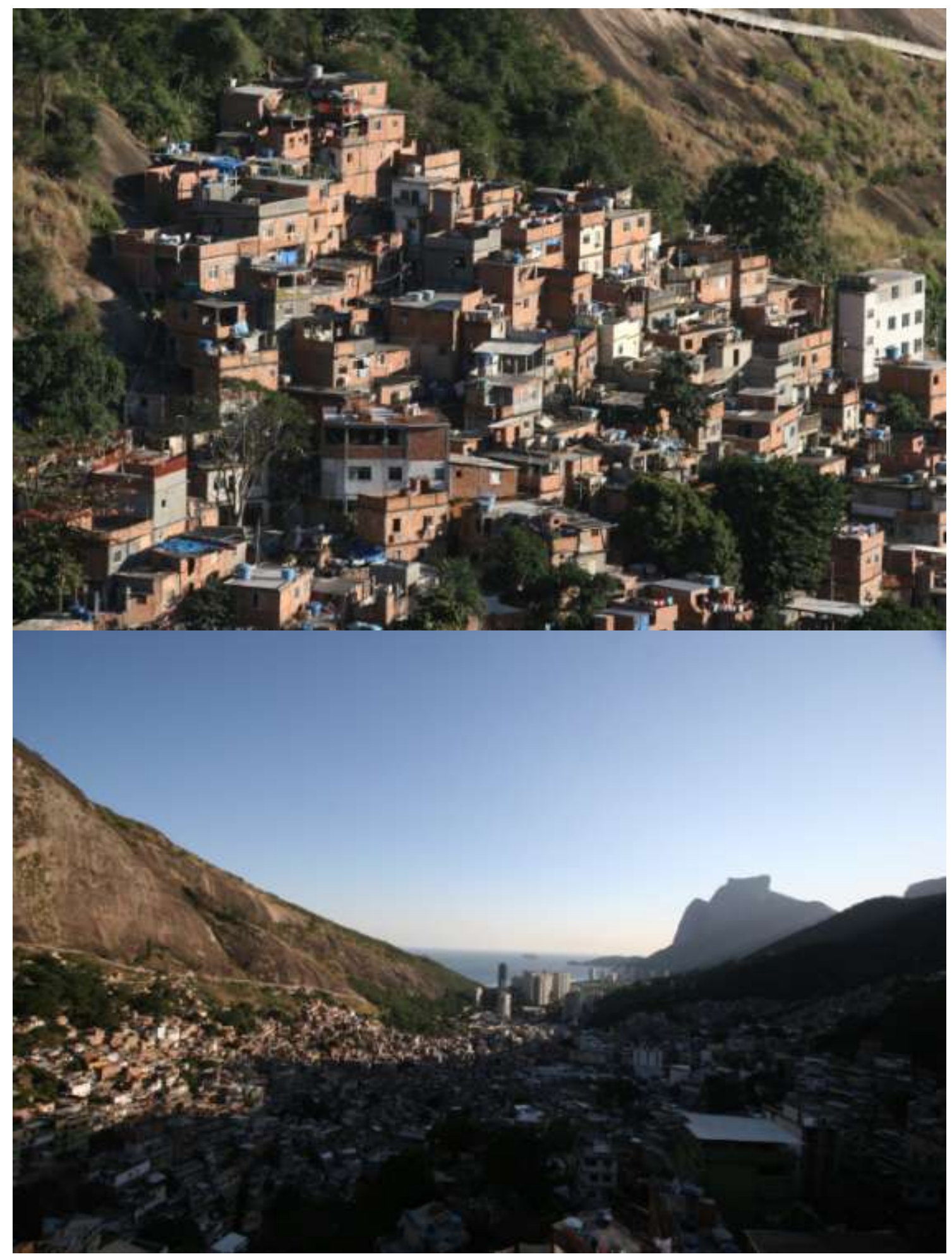




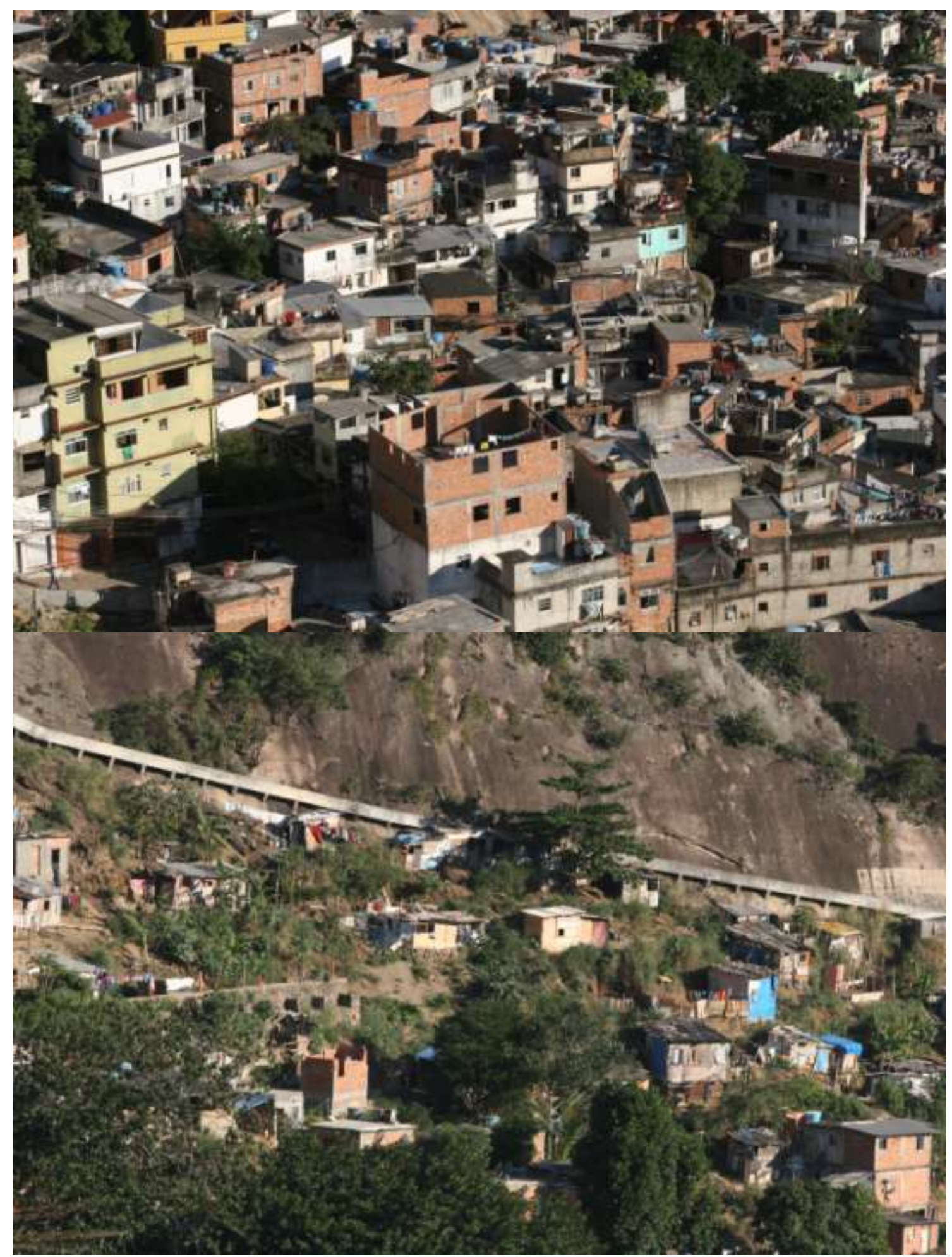




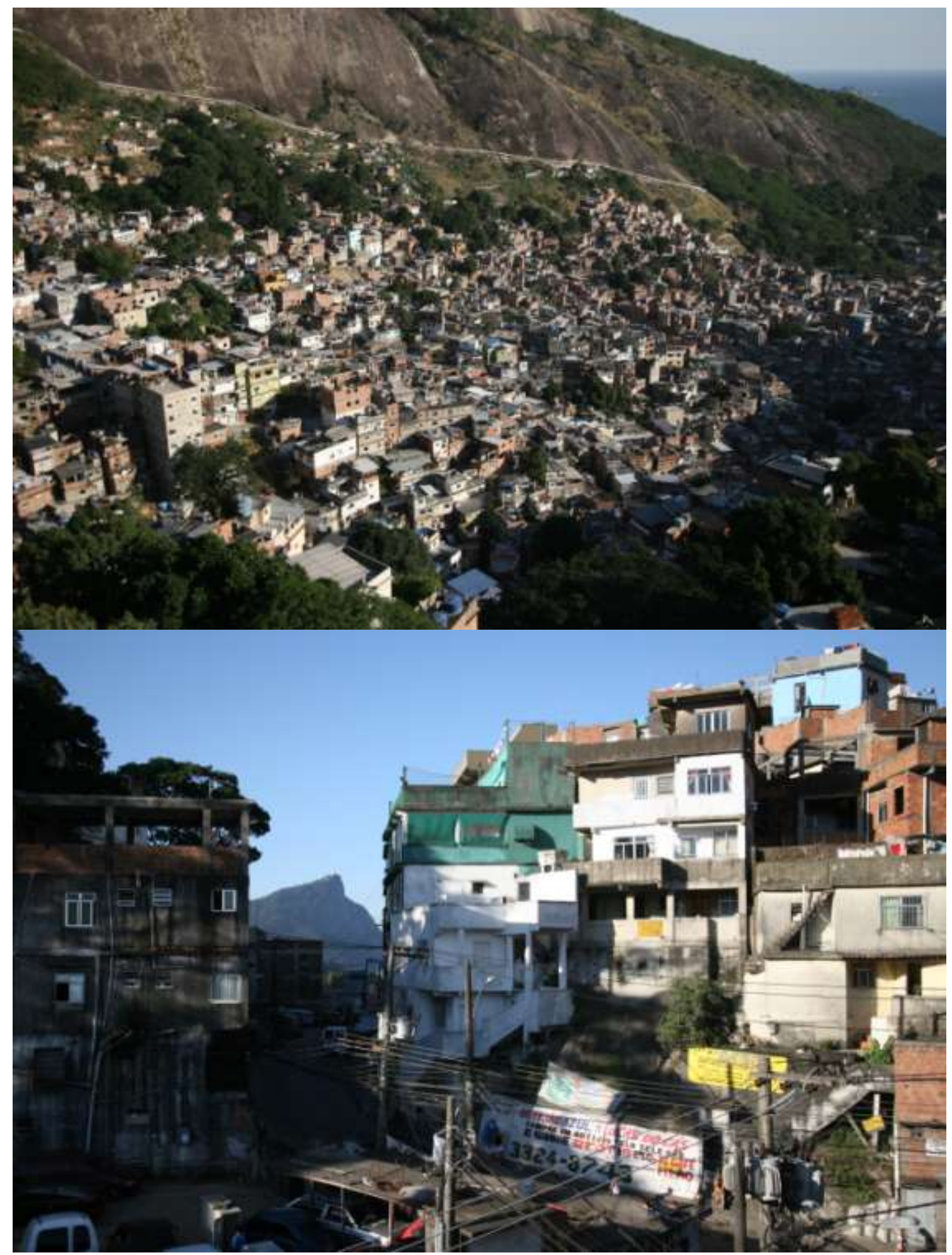




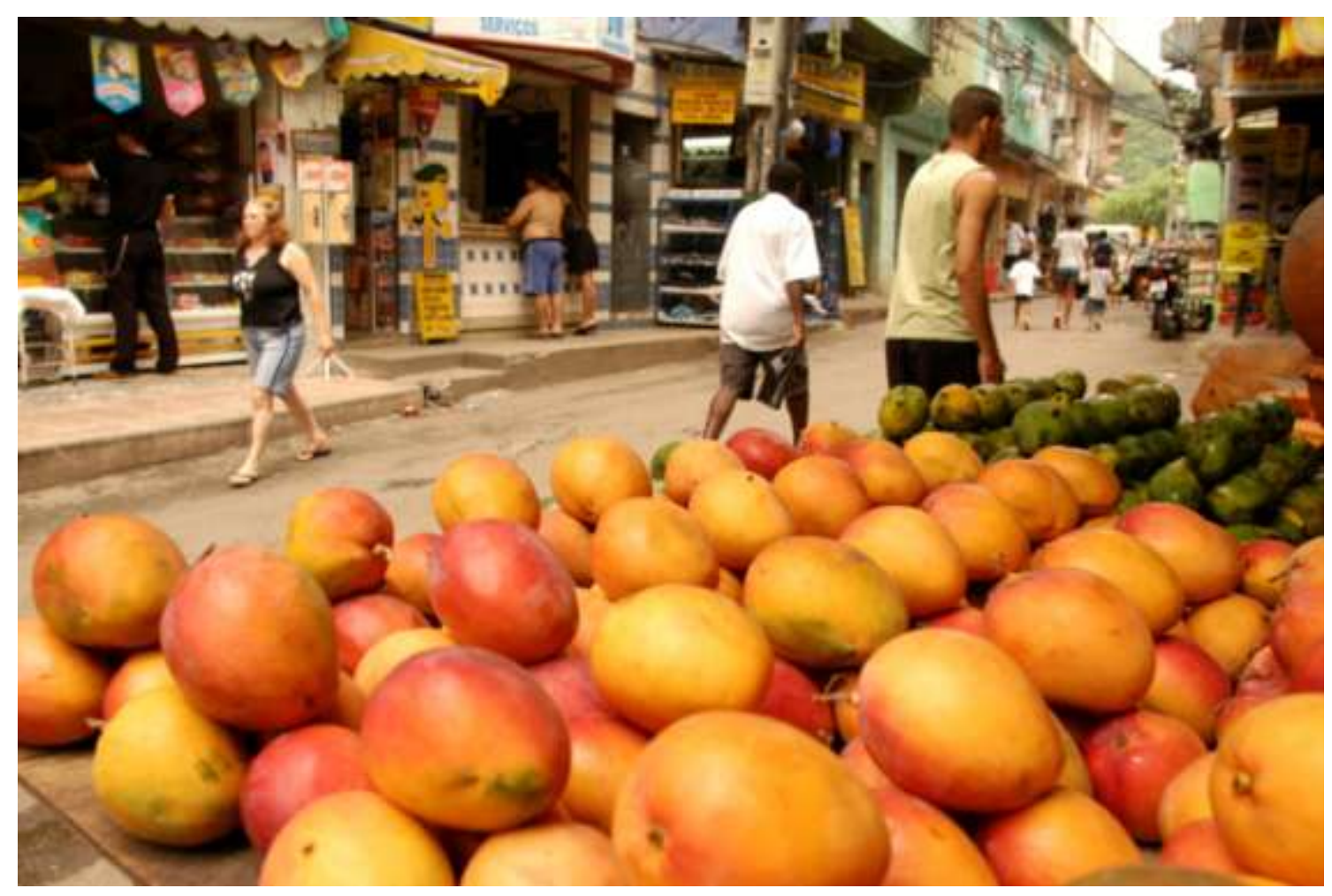


ANEXO 3 Lei 11.977 de 2009

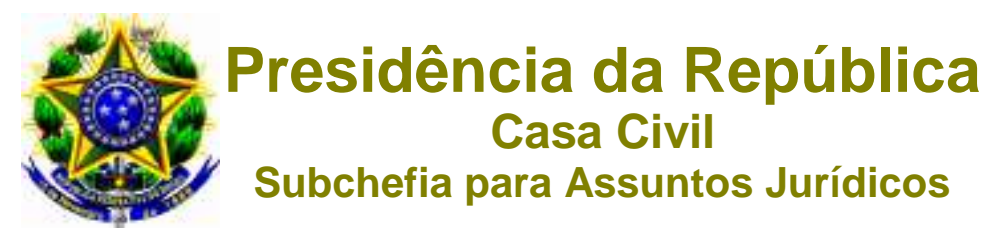

LEE № 11.977, DE 7 DE JULHO DE 2009.

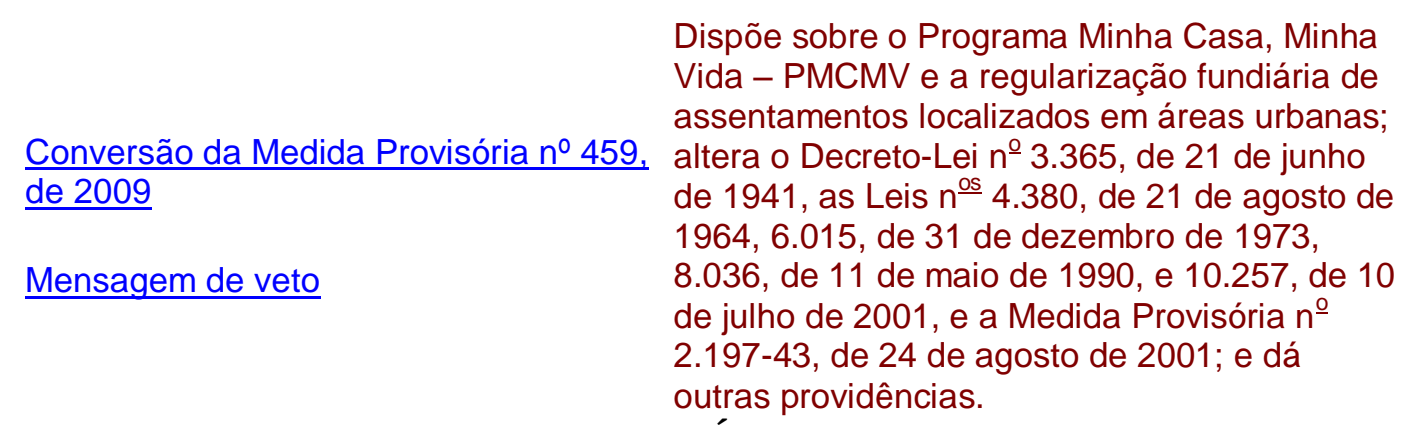

O VICE-PRESIDENTE DA REPÚBLICA, no exercício do cargo de PRESIDENTE DA REPÚBLICA Faço saber que o Congresso Nacional decreta e eu sanciono a seguinte Lei:

CAPÍTULO I
DO PROGRAMA MINHA CASA, MINHA VIDA - PMCMV
Seção I
$\underline{\text { Regulamento }}$

Da Estrutura e Finalidade do PMCMV

Art. 1o O Programa Minha Casa, Minha Vida - PMCMV compreende:

I - o Programa Nacional de Habitação Urbana - PNHU;

II - o Programa Nacional de Habitação Rural - PNHR;

III - a autorização para a União transferir recursos ao Fundo de Arrendamento Residencial - FAR e ao Fundo de Desenvolvimento Social - FDS;

IV - a autorização para a União conceder subvenção econômica tendo em vista a implementação do PMCMV em Municípios com população de até 50.000 (cinquenta mil) habitantes;

V - a autorização para a União participar do Fundo Garantidor da Habitação Popular - FGHab; e

VI - a autorização para a União conceder subvenção econômica ao Banco Nacional de Desenvolvimento Econômico e Social - BNDES.

Art. 2o 0 PMCMV tem como finalidade criar mecanismos de incentivo à produção e à aquisição de novas unidades habitacionais pelas famílias com renda mensal de até 10 (dez) salários mínimos, que residam em qualquer dos Municípios brasileiros.

Art. 3o Para a definição dos beneficiários do PMCMV, devem ser respeitadas, além das faixas de renda, as políticas estaduais e municipais de atendimento habitacional, priorizando-se, entre os critérios adotados, o tempo de residência ou de trabalho do candidato no Município e a adequação ambiental e urbanística dos projetos apresentados.

§ 1 Em áreas urbanas, os critérios de prioridade para atendimento devem contemplar também:

I - a doação pelos Estados, pelo Distrito Federal e pelos Municípios de terrenos localizados em área urbana consolidada para implantação de empreendimentos vinculados ao programa; 
II - a implementação pelos Estados, pelo Distrito Federal e pelos Municípios de medidas de desoneração tributária, para as construções destinadas à habitação de interesse social;

III - a implementação pelos Municípios dos instrumentos da Lei no 10.257, de 10 de julho de 2001, voltados ao controle da retenção das áreas urbanas em ociosidade.

\section{$\S 2^{\circ} \underline{\text { (VETADO) }}$}

$\S 3^{\circ}$ Terão prioridade como beneficiários os moradores de assentamentos irregulares ocupados por população de baixa renda que, em razão de estarem em áreas de risco ou de outros motivos justificados no projeto de regularização fundiária, excepcionalmente tiverem de ser relocados, não se lhes aplicando o sorteio referido no $\S 20$.

\section{Seção II \\ Regulamento \\ Do Programa Nacional de Habitação Urbana - PNHU}

Art. $4^{\circ}$ O Programa Nacional de Habitação Urbana - PNHU tem como objetivo subsidiar a produção e a aquisição de imóvel para os segmentos populacionais com renda familiar mensal de até 6 (seis) salários mínimos.

$\S 1^{\circ}$ Incluem-se entre as ações passíveis de serem realizadas no âmbito do PNHU:

I - produção ou aquisição de novas unidades habitacionais em áreas urbanas;

II - (VETADO);

III - requalificação de imóveis já existentes em áreas consolidadas.

$\S 2^{\circ}$ A assistência técnica deve fazer parte da composição de custos do PNHU.

Art. $5^{\circ}$ Fica a União autorizada a conceder subvenção econômica no âmbito do PNHU até o montante de R\$ 2.500.000.000,00 (dois bilhões e quinhentos milhões de reais).

Parágrafo único. Enquanto não efetivado o aporte de recursos de que trata o caput, caso o agente operador do Fundo de Garantia do Tempo de Serviço - FGTS tenha suportado ou venha a suportar, com recursos das disponibilidades atuais do referido fundo, a parcela da subvenção econômica de que trata o caput, terá direito ao ressarcimento das quantias desembolsadas, devidamente atualizadas pela taxa Selic.

Art. $6^{\circ}$ A subvenção econômica de que trata 0 art. $5^{\circ}$ será concedida exclusivamente a mutuários com renda familiar mensal de até 6 (seis) salários mínimos, somente no ato da contratação da operação de financiamento, com o objetivo de:

1- facilitar a aquisição do imóvel residencial; ou

I - facilitar a aquisição, produção e requalificação do imóvel residencial; ou (Redação dada pela Medida Provisória ํㅜ 472. de 2009)

II - complementar o valor necessário a assegurar o equilíbrio econômico-financeiro das operações de financiamento realizadas pelas entidades integrantes do Sistema Financeiro da Habitação - SFH, compreendendo as despesas de contratação, de administração e cobrança e de custos de alocação, remuneração e perda de capital.

$\S 1^{0}$ A subvenção econômica no âmbito do PNHU será concedida 1 (uma) única vez para cada beneficiário final e será cumulativa, até o limite máximo a ser fixado em ato do Poder Executivo, com os descontos habitacionais concedidos com recursos do Fundo de Garantia do Tempo de Serviço - FGTS, nas operações de financiamento realizadas na forma do art. $9^{\circ}$ da Lei $n^{\circ} 8.036$, de 11 de maio de 1990.

$\S 2^{0}$ A subvenção poderá ser cumulativa com subsídios concedidos no âmbito de programas habitacionais dos Estados, do Distrito Federal ou dos Municípios.

Art. $7^{\circ}$ Em casos de utilização dos recursos da subvenção de que trata o art. $5^{\circ}$ em finalidade diversa da definida nesta Lei, ou em desconformidade ao disposto no art. 6º, será exigida a devolução ao erário do valor da subvenção concedida, acrescido de juros e atualização monetária, com base na remuneração dos recursos que serviram de lastro à concessão da subvenção, sem prejuízo das penalidades previstas em lei.

Art. $8^{\circ}$ Caberá ao Poder Executivo a regulamentação do PNHU, especialmente em relação:

I - à fixação das diretrizes e condições gerais;

II - à distribuição regional dos recursos e à fixação dos critérios complementares de distribuição desses recursos;

III - aos valores e limites máximos de subvenção;

IV - ao estabelecimento dos critérios adicionais de priorização da concessão da subvenção econômica; e

V - ao estabelecimento das condições operacionais para pagamento e controle da subvenção econômica.

Art. $9^{\circ}$ A gestão operacional dos recursos de subvenção do PNHU será efetuada pela Caixa Econômica Federal.

Parágrafo único. Os Ministros de Estado das Cidades e da Fazenda fixarão, em ato conjunto, a remuneração da Caixa Econômica Federal pelas atividades exercidas no âmbito do PNHU.

Art. 10. Competem aos Ministérios da Fazenda e das Cidades a regulamentação e a gestão do PNHU no âmbito das suas respectivas competências. 
Do Programa Nacional de Habitação Rural - PNHR

Art. 11. O Programa Nacional de Habitação Rural - PNHR tem como finalidade subsidiar a produção ou a aquisição de moradia aos agricultores familiares, definidos nos termos do art. $3^{\theta}$ da Lei $n^{\theta} 11.326$, de 24 de julho de 2006 , e trabalhadores rurais.

Art. 11. O Programa Nacional de Habitação Rural - PNHR tem como finalidade subsidiar a produção de moradia aos agricultores familiares, definidos nos termos do art. $3^{\circ}$ da Lei $n^{0} 11.326$, de 24 de julho de 2006 , e trabalhadores rurais. (Redação dada pela Medida Provisória no 472, de 2009)

Parágrafo único. A assistência técnica deve fazer parte da composição de custos do PNHR.

§ 1ํ A assistência técnica deve fazer parte da composição de custos do PNHR. (Incluído pela Medida Provisória no 478, de 2009)

$\S$ 2ㅇ Para efeitos do PNHR, a produção compreende também a reforma de moradia. (Incluído pela Medida Provisória n ${ }^{\circ}$ 478, de 2009)

Art.12. Fica a União autorizada a conceder subvenção econômica no âmbito do PNHR até o montante de R\$ 500.000.000,00 (quinhentos milhões de reais).

Parágrafo único. Enquanto não efetivado o aporte de recursos de que trata o caput, caso o agente operador do Fundo de Garantia do Tempo de Serviço - FGTS tenha suportado ou venha a suportar, com recursos das disponibilidades atuais do referido fundo, a parcela da subvenção econômica de que trata o caput, terá direito ao ressarcimento das quantias desembolsadas, devidamente atualizadas pela taxa Selic.

Art. 13. A subvenção econômica de que trata o art. 12 será concedida somente no ato da contratação da operação de financiamento, com o objetivo de:

1- facilitar a aquisição do imóvel residencial;

I - facilitar a produção do imóvel residencial; (Redação dada pela Medida Provisória no 472, de 2009)

II - complementar o valor necessário a assegurar o equilíbrio econômico-financeiro das operações de financiamento realizadas pelos agentes financeiros; ou

III - complementar a remuneração do agente financeiro, nos casos em que o subsídio não esteja vinculado a financiamento.

$\S 1^{\circ}$ A subvenção econômica no âmbito do PNHR será concedida 1 (uma) única vez para cada beneficiário final e será cumulativa, até o limite máximo a ser fixado em ato do Poder Executivo, com os descontos habitacionais concedidos com recursos do Fundo de Garantia do Tempo de Serviço - FGTS, nas operações de financiamento realizadas na forma do art. $9^{\circ}$ da Lei $n^{\circ} 8.036$, de 11 de maio de 1990.

$\S 2^{0}$ A subvenção poderá ser cumulativa com subsídios concedidos no âmbito de programas habitacionais dos Estados, Distrito Federal ou Municípios.

$\S 3^{\ominus}$ - A concessão da subvenção econômica deverá guardar proporcionalidade com a renda familiar e o valor do imóvel, além de considerar as diferenças regionais.

$\S 3^{\circ}$ Para definição dos beneficiários do PNHR devem ser respeitadas, exclusivamente, as faixas de renda, não se aplicando os demais critérios estabelecidos no art. 3ํ․ (Redação dada pela Medida Provisória no 472 , de 2009)

Art. 14. Em casos de utilização dos recursos da subvenção de que trata 0 art. 12 em finalidade diversa da definida nesta Lei, ou em desconformidade ao disposto no art. 13, será exigida a devolução ao erário do valor da subvenção concedida, acrescido de juros e atualização monetária, com base na remuneração dos recursos que serviram de lastro à concessão da subvenção, sem prejuízo das penalidades previstas em lei.

Art. 15. O Poder Executivo regulamentará o disposto nesta Seção, especialmente no que concerne à definição das diretrizes e condições gerais de operação, gestão, acompanhamento, controle e avaliação do PNHR.

Art. 16. A gestão operacional do PNHR será efetuada pela Caixa Econômica Federal.

Parágrafo único. Os Ministros de Estado das Cidades e da Fazenda fixarão, em ato conjunto, a remuneração da Caixa Econômica Federal pelas atividades exercidas no âmbito do PNHR.

Art. 17. Competem aos Ministérios da Fazenda e das Cidades a regulamentação e a gestão do PNHR no âmbito das suas respectivas competências.

\author{
Seção IV \\ Regulamento \\ Das Transferências de Recursos por parte da União e da \\ Subvenção para Municípios de Pequeno Porte
}

Art. 18. Fica a União autorizada a transferir recursos para o Fundo de Arrendamento Residencial - FAR, até o limite de $\mathrm{R} \$ 14.000 .000 .000,00$ (quatorze bilhões de reais), e para o Fundo de Desenvolvimento Social - FDS, até o limite de $R \$$ $500.000 .000,00$ (quinhentos milhões de reais).

$\S 1^{\Theta}$ - A liberação dos recursos pela União será efetuada no âmbito do PMCMV. 
$\S 1^{0}$ A liberação dos recursos de que trata o caput será efetuada no âmbito do PMCMV e ficará condicionada a que, nas operações realizadas com esses recursos: (Redação dada pela Lei ํㅜ 12.058, de 2009)

I - seja exigida a participação dos beneficiários sob a forma de prestações mensais; (Incluído pela Lei no 12.058, de 2009)

II - haja a quitação da operação, em casos de morte e invalidez permanente do mutuário, sem cobrança de contribuição do beneficiário; e (Incluído pela Lei no 12.058, de 2009)

III - haja o custeio de danos físicos ao imóvel, sem cobrança de contribuição do beneficiário. (Incluído pela Lei oํ 12.058, de 2009)

$\S 2^{\circ}$ Enquanto não efetivado o aporte de recursos de que trata o caput, caso o agente operador do FAR tenha utilizado ou venha a utilizar as disponibilidades atuais do referido Fundo, em contratações no âmbito do PMCMV, terá o FAR direito ao ressarcimento das quantias desembolsadas, devidamente atualizadas pela taxa Selic.

Art. 19. Fica a União autorizada a conceder subvenção econômica, no montante de até $R \$ 1.000 .000 .000,00$ (um bilhão de reais), para implementação do PMCMV em Municípios com população de até 50.000 (cinquenta mil) habitantes e para atendimento a beneficiários com renda familiar mensal de até 3 (três) salários mínimos, por meio de instituições financeiras autorizadas pelo Banco Central do Brasil ou de agentes financeiros do Sistema Financeiro da Habitação - SFH.

$\S 1^{\circ}$ Os recursos referidos no caput serão alocados mediante oferta pública às instituições financeiras e aos agentes financeiros, a critério dos Ministérios da Fazenda e das Cidades.

$\S 2^{\circ}$ Cada instituição financeira ou agente financeiro participante só poderá receber recursos até o máximo de 15\% (quinze por cento) do total ofertado em cada oferta pública.

$\S 3^{\circ}$ A regulamentação deste artigo disporá necessariamente sobre os seguintes aspectos:

I - os valores e limites das subvenções individualizadas a serem destinadas a cada beneficiário;

II - a remuneração das instituições financeiras ou dos agentes financeiros pelas operações realizadas;

III - as condições e modalidades de ofertas públicas de cotas de subvenções, como também sua quantidade;

IV - a tipologia e o padrão das moradias e da infraestrutura urbana;

V - a permissão pelo Banco Central do Brasil, na esfera de sua competência e a seu exclusivo critério e discrição, para que as instituições financeiras referidas no caput possam realizar operações no âmbito do PMCMV;

VI - a atribuição ao Conselho Monetário Nacional - CMN para definir as instituições financeiras e os agentes financeiros do SFH referidos no caput; e

VII - a permissão pelos Ministérios da Fazenda e das Cidades, na esfera de sua competência e a seu exclusivo critério, para que as instituições financeiras e os agentes financeiros do SFH definidos pelo CMN possam realizar operações no âmbito do PMCMV.

$\S 4^{\circ}$ Os Estados e os Municípios poderão complementar o valor dos repasses com créditos tributários, benefícios fiscais, bens ou serviços economicamente mensuráveis, assistência técnica ou recursos financeiros.

$\S 5^{\circ}$ A aplicação das condições previstas neste artigo dar-se-á sem prejuízo da possibilidade de atendimento aos Municípios de que trata o caput por outras formas admissíveis no âmbito do PMCMV.

\section{Seção V \\ Do Fundo Garantidor da Habitação Popular - FGHab}

Art. 20. Fica a União autorizada a participar, até o limite de $R \$ 2.000 .000 .000,00$ (dois bilhões de reais), de Fundo Garantidor da Habitação Popular - FGHab, que terá por finalidades:

I - garantir o pagamento aos agentes financeiros de prestação mensal de financiamento habitacional, no âmbito do Sistema Financeiro da Habitação, devida por mutuário final, em caso de desemprego e redução temporária da capacidade de pagamento, para famílias com renda mensal de até 10 (dez) salários mínimos; e

II - assumir o saldo devedor do financiamento imobiliário, em caso de morte e invalidez permanente, e as despesas de recuperação relativas a danos físicos ao imóvel para mutuários com renda familiar mensal de até 10 (dez) salários mínimos.

$\S 1^{\underline{\theta}}$-As condições e os limites das coberturas de que tratam os incisos le ll deste artigo serão definidos no estatuto do EGHab.

$\S 1^{0}$ As condições e os limites das coberturas de que tratam os incisos I e II deste artigo serão definidos no estatuto do FGHab, que poderá estabelecer os casos em que será oferecida somente a cobertura de que trata o inciso II. (Redação dada pela Medida Provisória ํㅡ 472, de 2009)

$\S 2^{\circ}$ O FGHab terá natureza privada e patrimônio próprio dividido em cotas, separado do patrimônio dos cotistas.

$\S 3^{\circ}$ Constituem patrimônio do FGHab:

I - os recursos oriundos da integralização de cotas pela União e pelos agentes financeiros que optarem por aderir às coberturas previstas nos incisos I e II do caput deste artigo;

II - os rendimentos obtidos com a aplicação das disponibilidades financeiras em títulos públicos federais e em ativos com lastro em créditos de base imobiliária, cuja aplicação esteja prevista no estatuto social;

III - os recursos provenientes da recuperação de prestações honradas com recursos do FGHab;

IV - as comissões cobradas com fundamento nos incisos I e II do caput deste artigo; e

$V$ - outras fontes de recursos definidas no estatuto do Fundo. 
$\S 4^{\circ}$ Os agentes financeiros que optarem por aderir à cobertura do FGHab deverão integralizar cotas proporcionais ao valor do financiamento para o mutuário final, na forma definida pelo estatuto.

$\S 5^{\circ}$ A integralização de cotas pela União será autorizada por decreto e poderá ser realizada, a critério do Ministério da Fazenda:

I - em moeda corrente;

II - em títulos públicos;

III - por meio de suas participações minoritárias; ou

IV - por meio de ações de sociedades de economia mista federais excedentes ao necessário para manutenção de seu controle acionário.

$\S 6^{\circ}$ O FGHab terá direitos e obrigações próprias, pelas quais responderá com seu patrimônio, não respondendo os cotistas por qualquer obrigação do Fundo, salvo pela integralização das cotas que subscreverem.

Art. 21. É facultada a constituição de patrimônio de afetação para a cobertura de que trata o inciso II do caput do art. 20, que não se comunicará com o restante do patrimônio do $\mathrm{FGHab}$, ficando vinculado exclusivamente à garantia da respectiva cobertura, não podendo ser objeto de penhora, arresto, sequestro, busca e apreensão ou qualquer ato de constrição judicial decorrente de outras obrigações do Fundo.

Parágrafo único. A constituição do patrimônio de afetação será feita por registro em cartório de registro de títulos e documentos.

Art. 22. O FGHab não pagará rendimentos a seus cotistas, assegurando-se a qualquer deles o direito de requerer o resgate total ou parcial de suas cotas, correspondente ao montante de recursos financeiros disponíveis ainda não vinculados às garantias já contratadas, fazendo-se a liquidação com base na situação patrimonial do Fundo.

Art. 23. Os rendimentos auferidos pela carteira do FGHab não se sujeitam à incidência de imposto de renda na fonte, devendo integrar a base de cálculo dos impostos e contribuições devidos pela pessoa jurídica, na forma da legislação vigente, quando houver o resgate de cotas, total ou parcial, ou na dissolução do Fundo.

Art. 24. O FGHab será criado, administrado, gerido e representado judicial e extrajudicialmente por instituição financeira controlada direta ou indiretamente pela União, com observância das normas a que se refere o inciso XXII do art. $4^{\circ}$ da Lei $n^{\circ}$ 4.595, de 31 de dezembro de 1964.

$\S 1^{\circ}$ A representação da União na assembleia de cotistas dar-se-á na forma do inciso $V$ do art. 10 do Decreto-Lei $n^{\circ} 147$, de 3 de fevereiro de 1967.

$\S 2^{0}$ Caberá à instituição financeira de que trata o caput deste artigo, na forma estabelecida no estatuto do Fundo:

I- deliberar sobre a gestão e a alienação dos bens e direitos do FGHab, zelando pela manutenção de sua rentabilidade e liquidez, após autorização dos cotistas;

II - receber comissão pecuniária, em cada operação, do agente financeiro concedente do crédito, que poderá exigi-la do mutuário, desde que o valor cobrado do mutuário, somado a outras eventuais cobranças de caráter securitário, não ultrapasse 10\% (dez por cento) da prestação mensal.

$\S 3^{\circ} \mathrm{A}$ instituição financeira a que se refere o caput deste artigo fará jus à remuneração pela administração do FGHab, a ser estabelecida no estatuto do Fundo.

$\S 4^{\circ} \mathrm{O}$ estatuto do FGHab será proposto pela instituição financeira e aprovado em assembleia de cotistas.

Art. 25. Fica criado o Comitê de Participação no Fundo Garantidor da Habitação Popular - CPFGHab, órgão colegiado com composição e competência estabelecidas em ato do Poder Executivo.

$\S 1^{\circ}$ O CPFGHab contará com representantes do Ministério da Fazenda, que o presidirá, do Ministério do Planejamento, Orçamento e Gestão e da Casa Civil da Presidência da República.

$\S 2^{\circ}$ O estatuto do FGHab deverá ser examinado previamente pelo CPFGHab antes de sua aprovação na assembleia de cotistas.

Art. 26. O FGHab não contará com qualquer tipo de garantia ou aval por parte do setor público e responderá por suas obrigações até o limite dos bens e direitos integrantes de seu patrimônio.

Art. 27. A garantia de que trata o inciso I do caput do art. 20 será prestada mediante as seguintes condições:

I - limite de cobertura, incluindo o número de prestações cobertas, a depender da renda familiar do mutuário, verificada no ato da contratação;

II - período de carência definido pelo estatuto;

III - retorno das prestações honradas pelo Fundo na forma contratada com o mutuário final, imediatamente após o término de cada período de utilização da garantia, dentro do prazo remanescente do financiamento habitacional ou com prorrogação do prazo inicial, atualizadas pelos mesmos índices previstos no contrato de financiamento; e

IV - risco de crédito compartilhado entre o Fundo e os agentes financeiros nos percentuais, respectivamente, de $95 \%$ (noventa e cinco por cento) e 5\% (cinco por cento), a ser absorvido após esgotadas medidas de cobrança e execução dos valores honrados pelo FGHab.

Art. 28. Os financiamentos imobiliários garantidos pelo FGHab, na forma do inciso Il do caput do art. 20, serão dispensados da contratação de seguro com cobertura de Morte, Invalidez Permanente - MIP e Danos Físicos ao Imóvel DFI.

Art. 29. O FGHab concederá garantia para até 600.000 (seiscentos mil) financiamentos imobiliários contratados exclusivamente no âmbito do PMCMV.

Art. 30. As coberturas do FGHab, descritas no art. 20, serão prestadas às operaçẽes de financiamento habitacional que obedeçam às seguintes condições: 
1 - aquisição de imóveis novos, com valores de financiamento limitados aos definidos no estatuto do Fundo;

H- cobertura para somente um único imóvel financiado por mutuário no âmbito do Sistema Financeiro da Habitação; e-

III - previsão da cobertura pelo FGHab expressa em cláusula específica dos contratos celebrados entre os agentes financeiros e os mutuários finais.

Parágrafo único. O estatuto do FGHab definirá o prazo das coberturas oferecidas pelo Fundo.

Art. 30. As coberturas do FGHab, descritas no art. 20, serão prestadas às operações de financiamento habitacional nos casos de: (Redação dada pela Medida Provisória no 472, de 2009)

I - produção ou aquisição de imóveis novos em áreas urbanas; (Redação dada pela Medida Provisória no 472 , de 2009)

II - requalificação de imóveis já existentes em áreas consolidadas no âmbito do Programa Nacional de Habitação Urbana - PNHU; ou (Redacão dada pela Medida Provisória no 472, de 2009)

III - produção de moradia no âmbito do Programa Nacional de Habitação Rural - PNHR. (Redação dada pela Medida Provisória no 472, de 2009)

$\S 1^{0}$ A contratação das coberturas de que trata o caput está sujeita às seguintes condições: (Incluído pela Medida Provisória no 472, de 2009)

I - os valores de financiamento devem obedecer aos limites definidos no estatuto do Fundo; (Incluído pela Medida Provisória no 472, de 2009)

II - a cobertura do FGHab está limitada a um único imóvel financiado por mutuário no âmbito do SFH; e (Incluído pela Medida Provisória no 472, de 2009)

III - a previsão da cobertura pelo FGHab deve estar expressa em cláusula específica dos contratos celebrados entre os agentes financeiros e os mutuários. (Incluído pela Medida Provisória ํㅡ 472, de 2009)

$\S 2^{\circ} \mathrm{O}$ estatuto do FGHab definirá o prazo das coberturas oferecidas pelo Fundo. (Renumerado pelo parágrafo único pela Medida Provisória ํㅜ 472, de 2009)

Art. 31. A dissolução do FGHab ficará condicionada à prévia quitação da totalidade dos débitos garantidos.

Art. 32. Dissolvido o FGHab, o seu patrimônio será distribuído entre os cotistas, na proporção de suas cotas, com base na situação patrimonial à data da dissolução.

\section{Seção VI}

Da Subvenção Econômica ao Banco Nacional de Desenvolvimento Econômico e Social - BNDES

Art. 33. Fica a União autorizada a conceder subvenção econômica ao BNDES, sob a modalidade de equalização de taxas de juros e outros encargos financeiros, especificamente nas operações de financiamento de linha especial para infraestrutura em projetos de habitação popular.

$\S 1^{\circ} \mathrm{O}$ volume de recursos utilizado para a linha de que dispõe o caput deste artigo não pode superar $\mathrm{R} \$$ $5.000 .000 .000,00$ (cinco bilhões de reais).

$\S 2^{\circ}$ A equalização de juros de que trata o caput deste artigo corresponderá ao diferencial entre o custo da fonte de captação do BNDES e o custo da linha para a instituição financeira oficial federal.

Art. 34. A concessão da subvenção de equalização de juros obedecerá aos limites e normas operacionais a serem estabelecidos pelo Conselho Monetário Nacional, especialmente no que diz respeito a custos de captação e de aplicação dos recursos.

\section{Seção VII \\ Disposições Complementares}

Art. 35. Os contratos e registros efetivados no âmbito do PMCMV serão formalizados, preferencialmente, em nome da mulher.

Art. 36. Os lotes destinados à construção de moradias no âmbito do PMCMV não poderão ser objeto de remembramento, devendo tal proibição constar expressamente dos contratos celebrados.

Parágrafo único. A vedação estabelecida no caput perdurará pelo prazo de 15 (quinze) anos, contados a partir da celebração do contrato.

\section{CAPÍTULO II \\ Regulamento \\ DO REGISTRO ELETRÔNICO E DAS CUSTAS E EMOLUMENTOS}

Art. 37. Os serviços de registros públicos de que trata a Lei $n^{\circ} 6.015$, de 31 de dezembro de 1973, observados os prazos e condições previstas em regulamento, instituirão sistema de registro eletrônico. 
Art. 38. Os documentos eletrônicos apresentados aos serviços de registros públicos ou por eles expedidos deverão atender aos requisitos da Infraestrutura de Chaves Públicas Brasileira - ICP e à arquitetura e-PING (Padrões de Interoperabilidade de Governo Eletrônico), conforme regulamento.

Parágrafo único. Os serviços de registros públicos disponibilizarão serviços de recepção de títulos e de fornecimento de informações e certidões em meio eletrônico.

Art. 39. Os atos registrais praticados a partir da vigência da Lei $n^{\circ} 6.015$, de 31 de dezembro de 1973 , serão inseridos no sistema de registro eletrônico, no prazo de até 5 (cinco) anos a contar da publicação desta Lei.

Parágrafo único. Os atos praticados e os documentos arquivados anteriormente à vigência da Lei ํㅡ 6.015 , de 31 de dezembro de 1973, deverão ser inseridos no sistema eletrônico.

Art. 40. Serão definidos em regulamento os requisitos quanto a cópias de segurança de documentos e de livros escriturados de forma eletrônica.

Art. 41. A partir da implementação do sistema de registro eletrônico de que trata o art. 37, os serviços de registros públicos disponibilizarão ao Poder Executivo federal, por meio eletrônico e sem ônus, o acesso às informações constantes de seus bancos de dados, conforme regulamento.

Art. 42. As custas e os emolumentos devidos pelos atos de abertura de matrícula, registro de incorporação, parcelamento do solo, averbação de construção, instituição de condomínio, registro da carta de habite-se e demais atos referentes à construção de empreendimentos no âmbito do PMCMV serão reduzidos em:

I-90\% (noventa por cento) para a construção de unidades habitacionais de até $R \$ 60.000,00$ (sessenta mil reais);

II - 80\% (oitenta por cento) para a construção de unidades habitacionais de $R \$ 60.000,01$ (sessenta mil reais e um centavo) a $R \$ 80.000,00$ (oitenta mil reais); e

III - 75\% (setenta e cinco por cento) para a construção de unidades habitacionais de $R \$ 80.000,01$ (oitenta mil reais e um centavo) a $R \$ 130.000,00$ (cento e trinta mil reais).

Art. 43. Não serão devidas custas e emolumentos referentes a escritura pública, quando esta for exigida, ao registro da alienação de imóvel e de correspondentes garantias reais, e aos demais atos relativos ao primeiro imóvel residencial adquirido ou financiado pelo beneficiário com renda familiar mensal de até 3 (três) salários mínimos.

Parágrafo único. As custas e emolumentos de que trata o caput, no âmbito do PMCMV, serão reduzidos em:

I-80\% (oitenta por cento), quando os imóveis residenciais forem destinados a beneficiário com renda familiar mensal superior a 6 (seis) e até 10 (dez) salários mínimos; e

II - 90\% (noventa por cento), quando os imóveis residenciais forem destinados a beneficiário com renda familiar mensal superior a 3 (três) e igual ou inferior a 6 (seis) salários mínimos.

Art. 44. Os cartórios que não cumprirem o disposto nos arts. 42 e 43 ficarão sujeitos à multa no valor de até $R \$$ 100.000,00 (cem mil reais), bem como a outras sanções previstas na Lei $n^{\circ} 8.935$, de 18 de novembro de 1994 .

Art. 45. Regulamento disporá sobre as condições e as etapas mínimas, bem como sobre os prazos máximos, a serem cumpridos pelos serviços de registros públicos, com vistas na efetiva implementação do sistema de registro eletrônico de que trata 0 art. 37.

\title{
CAPÍTULO III \\ DA REGULARIZAÇÃO FUNDIÁRIA DE ASSENTAMENTOS URBANOS
}

\author{
Seção 1 \\ Disposições Preliminares
}

Art. 46. A regularização fundiária consiste no conjunto de medidas jurídicas, urbanísticas, ambientais e sociais que visam à regularização de assentamentos irregulares e à titulação de seus ocupantes, de modo a garantir o direito social à moradia, o pleno desenvolvimento das funções sociais da propriedade urbana e o direito ao meio ambiente ecologicamente equilibrado.

Art. 47. Para efeitos da regularização fundiária de assentamentos urbanos, consideram-se:

I - área urbana: parcela do território, contínua ou não, incluída no perímetro urbano pelo Plano Diretor ou por lei municipal específica;

II - área urbana consolidada: parcela da área urbana com densidade demográfica superior a 50 (cinquenta) habitantes por hectare e malha viária implantada e que tenha, no mínimo, 2 (dois) dos seguintes equipamentos de infraestrutura urbana implantados:

a) drenagem de águas pluviais urbanas;

b) esgotamento sanitário;

c) abastecimento de água potável;

d) distribuição de energia elétrica; ou

e) limpeza urbana, coleta e manejo de resíduos sólidos;

III - demarcação urbanística: procedimento administrativo pelo qual o poder público, no âmbito da regularização fundiária de interesse social, demarca imóvel de domínio público ou privado, definindo seus limites, área, localização e confrontantes, com a finalidade de identificar seus ocupantes e qualificar a natureza e o tempo das respectivas posses;

IV - legitimação de posse: ato do poder público destinado a conferir título de reconhecimento de posse de imóvel objeto de demarcação urbanística, com a identificação do ocupante e do tempo e natureza da posse; 
V - Zona Especial de Interesse Social - ZEIS: parcela de área urbana instituída pelo Plano Diretor ou definida por outra lei municipal, destinada predominantemente à moradia de população de baixa renda e sujeita a regras específicas de parcelamento, uso e ocupação do solo;

$\mathrm{VI}$ - assentamentos irregulares: ocupações inseridas em parcelamentos informais ou irregulares, localizadas em áreas urbanas públicas ou privadas, utilizadas predominantemente para fins de moradia;

VII - regularização fundiária de interesse social: regularização fundiária de assentamentos irregulares ocupados, predominantemente, por população de baixa renda, nos casos:

a) em que tenham sido preenchidos os requisitos para usucapião ou concessão de uso especial para fins de moradia;

b) de imóveis situados em ZEIS; ou

c) de áreas da União, dos Estados, do Distrito Federal e dos Municípios declaradas de interesse para implantação de projetos de regularização fundiária de interesse social;

VIII - regularização fundiária de interesse específico: regularização fundiária quando não caracterizado o interesse social nos termos do inciso VII.

Art. 48. Respeitadas as diretrizes gerais da política urbana estabelecidas na Lei $n^{\circ} 10.257$, de 10 de julho de 2001, a regularização fundiária observará os seguintes princípios:

I - ampliação do acesso à terra urbanizada pela população de baixa renda, com prioridade para sua permanência na área ocupada, assegurados o nível adequado de habitabilidade e a melhoria das condições de sustentabilidade urbanística, social e ambiental;

II - articulação com as políticas setoriais de habitação, de meio ambiente, de saneamento básico e de mobilidade urbana, nos diferentes níveis de governo e com as iniciativas públicas e privadas, voltadas à integração social e à geração de emprego e renda;

III - participação dos interessados em todas as etapas do processo de regularização;

IV - estímulo à resolução extrajudicial de conflitos; e

$\mathrm{V}$ - concessão do título preferencialmente para a mulher.

Art. 49. Observado o disposto nesta Lei e na Lei ํㅜ 10.257, de 10 de julho de 2001, o Município poderá dispor sobre o procedimento de regularização fundiária em seu território.

Parágrafo único. A ausência da regulamentação prevista no caput não obsta a implementação da regularização fundiária.

Art. 50. A regularização fundiária poderá ser promovida pela União, pelos Estados, pelo Distrito Federal e pelos Municípios e também por:

I - seus beneficiários, individual ou coletivamente; e

II - cooperativas habitacionais, associações de moradores, fundações, organizações sociais, organizações da sociedade civil de interesse público ou outras associações civis que tenham por finalidade atividades nas áreas de desenvolvimento urbano ou regularização fundiária.

Art. 51. O projeto de regularização fundiária deverá definir, no mínimo, os seguintes elementos:

I - as áreas ou lotes a serem regularizados e, se houver necessidade, as edificações que serão relocadas;

II - as vias de circulação existentes ou projetadas e, se possível, as outras áreas destinadas a uso público;

III - as medidas necessárias para a promoção da sustentabilidade urbanística, social e ambiental da área ocupada, incluindo as compensações urbanísticas e ambientais previstas em lei;

IV - as condições para promover a segurança da população em situações de risco; e

$\mathrm{V}$ - as medidas previstas para adequação da infraestrutura básica.

$\S 1^{\circ}$ O projeto de que trata o caput não será exigido para o registro da sentença de usucapião, da sentença declaratória ou da planta, elaborada para outorga administrativa, de concessão de uso especial para fins de moradia.

$\S 2^{\circ}$ O Município definirá os requisitos para elaboração do projeto de que trata o caput, no que se refere aos desenhos, ao memorial descritivo e ao cronograma físico de obras e serviços a serem realizados.

$\S 3^{\circ}$ A regularização fundiária pode ser implementada por etapas.

Art. 52. Na regularização fundiária de assentamentos consolidados anteriormente à publicação desta Lei, o Município poderá autorizar a redução do percentual de áreas destinadas ao uso público e da área mínima dos lotes definidos na legislação de parcelamento do solo urbano.

\section{Seção II \\ Da Regularização fundiária de Interesse Social}

Art. 53. A regularização fundiária de interesse social depende da análise e da aprovação pelo Município do projeto de que trata 0 art. 51.

Parágrafo único. A aprovação municipal prevista no caput corresponde ao licenciamento ambiental e urbanístico do projeto de regularização fundiária de interesse social, desde que o Município tenha conselho de meio ambiente e órgão ambiental capacitado.

Art. 54. O projeto de regularização fundiária de interesse social deverá considerar as características da ocupação e da área ocupada para definir parâmetros urbanísticos e ambientais específicos, além de identificar os lotes, as vias de circul ação e as áreas destinadas a uso público. 
$\S 1^{0}$ O Município poderá, por decisão motivada, admitir a regularização fundiária de interesse social em Áreas de Preservação Permanente, ocupadas até 31 de dezembro de 2007 e inseridas em área urbana consolidada, desde que estudo técnico comprove que esta intervenção implica a melhoria das condições ambientais em relação à situação de ocupação irregular anterior.

$\S 2^{\circ}$ O estudo técnico referido no $\S 1^{0}$ deverá ser elaborado por profissional legalmente habilitado, compatibilizar-se com o projeto de regularização fundiária e conter, no mínimo, os seguintes elementos:

I - caracterização da situação ambiental da área a ser regularizada;

II - especificação dos sistemas de saneamento básico;

III - proposição de intervenções para o controle de riscos geotécnicos e de inundações;

IV - recuperação de áreas degradadas e daquelas não passíveis de regularização;

V - comprovação da melhoria das condições de sustentabilidade urbano-ambiental, considerados o uso adequado dos recursos hídricos e a proteção das unidades de conservação, quando for o caso;

$\mathrm{VI}$ - comprovação da melhoria da habitabilidade dos moradores propiciada pela regularização proposta; e

VII - garantia de acesso público às praias e aos corpos d'água, quando for o caso.

Art. 55. Na regularização fundiária de interesse social, caberá ao poder público, diretamente ou por meio de seus concessionários ou permissionários de serviços públicos, a implantação do sistema viário e da infraestrutura básica, previstos no $\S 6^{\circ}$ do art. $2^{\circ}$ da Lei $n^{\circ} 6.766$, de 19 de dezembro de 1979 , ainda que promovida pelos legitimados previstos nos incisos I e ll do art. 50 .

Parágrafo único. A realização de obras de implantação de infraestrutura básica e de equipamentos comunitários pelo poder público, bem como sua manutenção, pode ser realizada mesmo antes de concluída a regularização jurídica das situações dominiais dos imóveis.

Art. 56. O poder público responsável pela regularização fundiária de interesse social poderá lavrar auto de demarcação urbanística, com base no levantamento da situação da área a ser regularizada e na caracterização da ocupação.

$\S 1^{\circ} \mathrm{O}$ auto de demarcação urbanística deve ser instruído com:

I - planta e memorial descritivo da área a ser regularizada, nos quais constem suas medidas perimetrais, área total, confrontantes, coordenadas preferencialmente georreferenciadas dos vértices definidores de seus limites, bem como seu número de matrícula ou transcrição e a indicação do proprietário, se houver;

II - planta de sobreposição do imóvel demarcado com a situação da área constante no registro de imóveis; e

III - certidão da matrícula ou transcrição da área a ser regularizada, emitida pelo registro de imóveis, ou, diante de sua inexistência, das circunscrições imobiliárias anteriormente competentes.

$\S 2^{\circ}$ Na possibilidade de a demarcação urbanística abranger área pública ou com ela confrontar, o poder público deverá notificar previamente os órgãos responsáveis pela administração patrimonial dos demais entes federados, para que informem se detêm a titularidade da área, no prazo de 30 (trinta) dias.

$\S 3^{\circ} \mathrm{Na}$ ausência de manifestação no prazo previsto no $\S 2^{2}$, o poder público dará continuidade à demarcação urbanística.

$\S 4^{0}$ No que se refere a áreas de domínio da União, aplicar-se-á o disposto na Seção III-A do Decreto-Lei $n^{\circ}$ 9.760, de 5 de setembro de 1946, inserida pela Lei $\mathrm{n}^{\circ} 11.481$, de 31 de maio de 2007, e, nas áreas de domínio dos Estados, Distrito Federal ou Municípios, a sua respectiva legislação patrimonial.

Art. 57. Encaminhado o auto de demarcação urbanística ao registro de imóveis, o oficial deverá proceder às buscas para identificação do proprietário da área a ser regularizada e de matrículas ou transcrições que a tenham por objeto.

$\S 1^{\circ}$ Realizadas as buscas, o oficial do registro de imóveis deverá notificar pessoalmente o proprietário da área e, por edital, os confrontantes e eventuais interessados para, querendo, apresentarem, no prazo de 15 (quinze) dias, impugnação à averbação da demarcação urbanística.

$\S 2^{\circ}$ Se o proprietário não for localizado nos endereços constantes do registro de imóveis ou naqueles fornecidos pelo poder público, a notificação do proprietário será realizada por edital.

$\S 3^{\circ}$ São requisitos para a notificação por edital:

I - resumo do auto de demarcação urbanística, com a descrição que permita a identificação da área a ser demarcada e seu desenho simplificado;

II - publicação do edital, no prazo máximo de 60 (sessenta) dias, uma vez pela imprensa oficial e uma vez em jornal de grande circulação local; e

III - determinação do prazo de 15 (quinze) dias para apresentação de impugnação à averbação da demarcação urbanística.

$\S 4^{0}$ Decorrido o prazo sem impugnação, a demarcação urbanística deverá ser averbada na matrícula da área a ser regularizada.

$\S 5^{\circ}$ Não havendo matrícula da qual a área seja objeto, esta deverá ser aberta com base na planta e no memorial indicados no inciso I do $\S 1^{\circ}$ do art. 56.

$\S 6^{0}$ Havendo impugnação, o oficial do registro de imóveis deverá notificar o poder público para que se manifeste no prazo de 60 (sessenta) dias.

$\S 7^{\circ}$ O poder público poderá propor a alteração do auto de demarcação urbanística ou adotar qualquer outra medida que possa afastar a oposição do proprietário ou dos confrontantes à regularização da área ocupada.

$\S 8^{\circ}$ Havendo impugnação apenas em relação à parcela da área objeto do auto de demarcação urbanística, o procedimento seguirá em relação à parcela não impugnada. 
$\S 9^{\circ}$ O oficial de registro de imóveis deverá promover tentativa de acordo entre o impugnante e o poder público.

$\S 10$. Não havendo acordo, a demarcação urbanística será encerrada em relação à área impugnada.

Art. 58. A partir da averbação do auto de demarcação urbanística, o poder público deverá elaborar o projeto previsto no art. 51 e submeter o parcelamento dele decorrente a registro.

$\S 1^{\circ}$ Após o registro do parcelamento de que trata o caput, o poder público concederá título de legitimação de posse aos ocupantes cadastrados.

$\S 2^{\circ}$ O título de que trata o $\S 1^{\circ}$ será concedido preferencialmente em nome da mulher e registrado na matrícula do imóvel.

Art. 59. A legitimação de posse devidamente registrada constitui direito em favor do detentor da posse direta para fins de moradia.

Parágrafo único. A legitimação de posse será concedida aos moradores cadastrados pelo poder público, desde que:

I - não sejam concessionários, foreiros ou proprietários de outro imóvel urbano ou rural;

II - não sejam beneficiários de legitimação de posse concedida anteriormente; e

III - os lotes ou fração ideal não sejam superiores a $250 \mathrm{~m}^{2}$ (duzentos e cinquenta metros quadrados).

Art. 60. Sem prejuízo dos direitos decorrentes da posse exercida anteriormente, o detentor do título de legitimação de posse, após 5 (cinco) anos de seu registro, poderá requerer ao oficial de registro de imóveis a conversão desse título em registro de propriedade, tendo em vista sua aquisição por usucapião, nos termos do art. 183 da Constituição Federal.

$\S 1^{\circ}$ Para requerer a conversão prevista no caput, o adquirente deverá apresentar:

I - certidões do cartório distribuidor demonstrando a inexistência de ações em andamento que versem sobre a posse ou a propriedade do imóvel;

II - declaração de que não possui outro imóvel urbano ou rural;

III - declaração de que o imóvel é utilizado para sua moradia ou de sua família; e

IV - declaração de que não teve reconhecido anteriormente o direito à usucapião de imóveis em áreas urbanas.

$\S 2^{\circ}$ As certidões previstas no inciso I do $\S 1^{\circ}$ serão relativas à totalidade da área e serão fornecidas pelo poder público.

\section{Seção III \\ Da Regularização fundiária de Interesse Específico}

Art. 61. A regularização fundiária de interesse específico depende da análise e da aprovação do projeto de que trata o art. 51 pela autoridade licenciadora, bem como da emissão das respectivas licenças urbanística e ambiental.

$\S 11^{\circ}$ O projeto de que trata o caput deverá observar as restrições à ocupação de Áreas de Preservação Permanente e demais disposições previstas na legislação ambiental.

$\S 2^{\circ} \mathrm{A}$ autoridade licenciadora poderá exigir contrapartida e compensações urbanísticas e ambientais, na forma da legislação vigente.

Art. 62. A autoridade licenciadora deverá definir, nas licenças urbanística e ambiental da regularização fundiária de interesse específico, as responsabilidades relativas à implantação:

I - do sistema viário;

II - da infraestrutura básica;

III - dos equipamentos comunitários definidos no projeto de regularização fundiária; e

IV - das medidas de mitigação e de compensação urbanística e ambiental eventualmente exigidas.

$\S 1^{\circ}$ A critério da autoridade licenciadora, as responsabilidades previstas no caput poderão ser compartilhadas com os beneficiários da regularização fundiária de interesse específico, com base na análise de, pelo menos, 2 (dois) aspectos:

I - os investimentos em infraestrutura e equipamentos comunitários já realizados pelos moradores; e

II - o poder aquisitivo da população a ser beneficiada.

$\S 2^{0}$ As medidas de mitigação e de compensação urbanística e ambiental exigidas na forma do inciso IV do caput deverão integrar termo de compromisso, firmado perante as autoridades responsáveis pela emissão das licenças urbanística e ambiental, ao qual se garantirá força de título executivo extrajudicial.

Art. 63. (VETADO)

\section{Seção IV}

\section{Do Registro da Regularização fundiária}

Art. 64. O registro do parcelamento resultante do projeto de regularização fundiária de interesse específico deverá ser requerido ao registro de imóveis, nos termos da legislação em vigor e observadas as disposições previstas neste Capítulo.

Art. 65. O registro do parcelamento resultante do projeto de regularização fundiária de interesse social deverá ser requerido ao registro de imóveis, acompanhado dos seguintes documentos:

I - certidão atualizada da matrícula do imóvel;

II - projeto de regularização fundiária aprovado;

III - instrumento de instituição e convenção de condomínio, se for o caso; e

IV - no caso das pessoas jurídicas relacionadas no inciso II do art. 50 , certidão atualizada de seus atos constitutivos que demonstrem sua legitimidade para promover a regularização fundiária. 
Art. 66. O registro do parcelamento resultante do projeto de regularização fundiária deverá importar:

I - na abertura de matrícula para toda a área objeto de regularização, se não houver; e

II - na abertura de matrícula para cada uma das parcelas resultantes do projeto de regularização fundiária.

Art. 67. As matrículas das áreas destinadas a uso público deverão ser abertas de ofício, com averbação das respectivas destinações e, se for o caso, das restrições administrativas convencionais ou legais.

Art. 68. Não serão cobradas custas e emolumentos para o registro do auto de demarcação urbanística, do título de legitimação e de sua conversão em título de propriedade e dos parcelamentos oriundos da regularização fundiária de interesse social.

\section{Seção V \\ Disposições Gerais}

Art. 69. Aplicam-se ao Distrito Federal todas as atribuições e prerrogativas dispostas neste Capítulo para os Estados e Municípios.

Art. 70. As matrículas oriundas de parcelamento resultante de regularização fundiária de interesse social não poderão ser objeto de remembramento.

Art. 71. As glebas parceladas para fins urbanos anteriormente a 19 de dezembro de 1979 que não possuírem registro poderão ter sua situação jurídica regularizada, com o registro do parcelamento, desde que o parcelamento esteja implantado e integrado à cidade.

$\S 1^{\circ}$ A regularização prevista no caput pode envolver a totalidade ou parcelas da gleba.

$\S 2^{\circ} \mathrm{O}$ interessado deverá apresentar certificação de que a gleba preenche as condições previstas no caput, bem como desenhos e documentos com as informações necessárias para a efetivação do registro do parcelamento.

\section{CAPÍTULO IV \\ DISPOSIÇÕES FINAIS}

Art. 72. Nas ações judiciais de cobrança ou execução de cotas de condomínio, de imposto sobre a propriedade predial e territorial urbana ou de outras obrigações vinculadas ou decorrentes da posse do imóvel urbano, nas quais o responsável pelo pagamento seja o possuidor investido nos respectivos direitos aquisitivos, assim como o usufrutuário ou outros titulares de direito real de uso, posse ou fruição, será notificado o titular do domínio pleno ou útil, inclusive o promitente vendedor ou fiduciário.

Art. 73. Serão assegurados no PMCMV:

I - condições de acessibilidade a todas as áreas públicas e de uso comum;

II - disponibilidade de unidades adaptáveis ao uso por pessoas com deficiência, com mobilidade reduzida e idosos, de acordo com a demanda;

III - condições de sustentabilidade das construções;

IV - uso de novas tecnologias construtivas.

Art. 74. O Decreto-Lei $n^{\circ} 3.365$, de 21 de junho de 1941, passa a vigorar com as seguintes alterações:

"Art. 15.

$\S 4^{\circ}$ A imissão provisória na posse será registrada no registro de imóveis competente." (NR)

"Art. 32.

$\S 1^{\circ}$ As dívidas fiscais serão deduzidas dos valores depositados, quando inscritas e ajuizadas.

$\S 2^{0}$ Incluem-se na disposição prevista no $\S 1^{\circ}$ as multas decorrentes de inadimplemento e de obrigações fiscais.

$\S 3^{\circ}$ A discussão acerca dos valores inscritos ou executados será realizada em ação própria." (NR)

Art. 75. A Lei $n^{\circ} 4.380$, de 21 de agosto de 1964, passa a vigorar com as seguintes alterações:

"Art. $8^{\circ}$

I - pelos bancos múltiplos;

II - pelos bancos comerciais;

III - pelas caixas econômicas;

IV - pelas sociedades de crédito imobiliário;

$V$ - pelas associações de poupança e empréstimo;

$\mathrm{VI}$ - pelas companhias hipotecárias; 
VII - pelos órgãos federais, estaduais e municipais, inclusive sociedades de economia mista em que haja participação majoritária do poder público, que operem, de acordo com o disposto nesta Lei, no financiamento de habitações e obras conexas;

VIII - pelas fundações, cooperativas e outras formas associativas para construção ou aquisição da casa própria sem finalidade de lucro, que se constituirão de acordo com as diretrizes desta Lei;

IX - pelas caixas militares;

$\mathrm{X}$ - pelas entidades abertas de previdência complementar;

$\mathrm{XI}$ - pelas companhias securitizadoras de crédito imobiliário; e

XII - por outras instituições que venham a ser consideradas pelo Conselho Monetário Nacional como integrantes do Sistema Financeiro da Habitação.

..$"(N R)$

"Art. 15-A. É permitida a pactuação de capitalização de juros com periodicidade mensal nas operações realizadas pelas entidades integrantes do Sistema Financeiro da Habitação - SFH.

$\S 1^{\circ}$ No ato da contratação e sempre que solicitado pelo devedor será apresentado pelo credor, por meio de planilha de cálculo que evidencie de modo claro e preciso, e de fácil entendimento e compreensão, o seguinte conjunto de informações:

I - saldo devedor e prazo remanescente do contrato;

II - taxa de juros contratual, nominal e efetiva, nas periodicidades mensal e anual;

III - valores repassados pela instituição credora às seguradoras, a título de pagamento de prêmio de seguro pelo mutuário, por tipo de seguro;

IV - taxas, custas e demais despesas cobradas juntamente com a prestação, discriminadas uma a uma;

$\mathrm{V}$ - somatório dos valores já pagos ou repassados relativos a:

a) juros;

b) amortização;

c) prêmio de seguro por tipo de seguro;

d) taxas, custas e demais despesas, discriminando por tipo;

$\mathrm{VI}$ - valor mensal projetado das prestações ainda não pagas, pelo prazo remanescente do contrato, e o respectivo somatório, decompostos em juros e amortizações;

VII - valor devido em multas e demais penalidades contratuais quando houver atraso no pagamento da prestação.

$\S 2^{\circ}$ No cômputo dos valores de que trata o inciso VI do $\S 1^{\circ}$, a instituição credora deve desconsiderar os efeitos de eventual previsão contratual de atualização monetária do saldo devedor ou das prestações."

"Art. 15-B. Nas operações de empréstimo ou financiamento realizadas por instituições integrantes do Sistema Financeiro da Habitação que prevejam pagamentos por meio de prestações periódicas, os sistemas de amortização do saldo devedor poderão ser livremente pactuados entre as partes.

$\S 1^{\circ} \mathrm{O}$ valor presente do fluxo futuro das prestações, compostas de amortização do principal e juros, geradas pelas operações de que trata o caput, deve ser calculado com a utilização da taxa de juros pactuada no contrato, não podendo resultar em valor diferente ao do empréstimo ou do financiamento concedido.

$\S 2^{\circ}$ No caso de empréstimos e financiamentos com previsão de atualização monetária do saldo devedor ou das

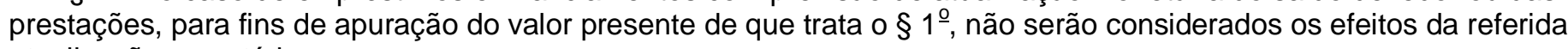
atualização monetária.

$\S 3^{0}$ Nas operações de empréstimo ou financiamento de que dispõe o caput é obrigatório o oferecimento ao mutuário do Sistema de Amortização Constante - SAC e de, no mínimo, outro sistema de amortização que atenda o disposto nos $\S \S 1^{\circ} \mathrm{e}$ $2^{\circ}$, entre eles o Sistema de Amortização Crescente - SACRE e o Sistema Francês de Amortização (Tabela Price)."

Art. 76. A Lei $n^{\circ} 6.015$, de 31 de dezembro de 1973, passa a vigorar com as seguintes alterações:

"Art. 17.

Parágrafo único. O acesso ou envio de informações aos registros públicos, quando forem realizados por meio da rede mundial de computadores (internet) deverão ser assinados com uso de certificado digital, que atenderá os requisitos da Infraestrutura de Chaves Públicas Brasileira - ICP." (NR)

"Art. 167.

$1-$

41. da legitimação de posse;

II- 
26. do auto de demarcação urbanística." (NR)

"Art. 221.

$\underline{V}$ - contratos ou termos administrativos, assinados com a União, Estados e Municípios no âmbito de programas de regularização fundiária, dispensado o reconhecimento de firma." (NR)

"Art. 237-A. Após o registro do parcelamento do solo ou da incorporação imobiliária, até a emissão da carta de habite-se, as averbações e registros relativos à pessoa do incorporador ou referentes a direitos reais de garantias, cessões ou demais negócios jurídicos que envolvam o empreendimento serão realizados na matrícula de origem do imóvel e em cada uma das matrículas das unidades autônomas eventualmente abertas.

$\S 1^{\circ}$ Para efeito de cobrança de custas e emolumentos, as averbações e os registros realizados com base no caput serão considerados como ato de registro único, não importando a quantidade de unidades autônomas envolvidas ou de atos intermediários existentes.

$\S 2^{\circ}$ Nos registros decorrentes de processo de parcelamento do solo ou de incorporação imobiliária, o registrador deverá observar o prazo máximo de 15 (quinze) dias para o fornecimento do número do registro ao interessado ou a indicação das pendências a serem satisfeitas para sua efetivação."

Art. 77. O inciso VII do art. 20 da Lei $n^{\circ} 8.036$, de 11 de maio de 1990, passa a vigorar com a seguinte redação:

"Art. 20.

VII - pagamento total ou parcial do preço de aquisição de moradia própria, ou lote urbanizado de interesse social não construído, observadas as seguintes condições:

..$"(N R)$

Art. 78. O inciso $V$ do art. $4^{\circ}$ da Lei $n^{\circ} 10.257$, de 10 de julho de 2001, passa a vigorar acrescido das seguintes alíneas $t$ e $u$ :

"Art. $4^{\circ}$

$\mathrm{V}-$

t) demarcação urbanística para fins de regularização fundiária;

u) legitimação de posse.

.$"(N R)$

Art. 79. O art. $2^{\ominus}$ da Medida Provisória $\mathrm{n}^{\theta}-2.197-43$, de 24 de agosto de 2001 , passa a vigorar com a seguinte redação:

"Art. $2^{\theta}$ - Os agentes financeiros do SFH somente poderão conceder financiamentos habitacionais com cobertura securitária que preveja, no mínimo, cobertura aos riscos de morte e invalidez permanente do mutuário e de danos físicos ao imóvel.

$\S 1^{\ominus}$-Para o cumprimento do disposto no caput, os agentes financeiros, respeitada a livre escolha do mutuário, deverão:

1-disponibilizar, na qualidade de estipulante e beneficiário, uma quantidade mínima de apólices emitidas por entes seguradores diversos, que observem a exigência estabelecida no caput;

II-aceitar apólices individuais apresentadas pelos pretendentes ao financiamento, desde que a cobertura securitária prevista observe a exigência mínima estabelecida no caput e o ente segurador cumpra as condições estabelecidas pelo Conselho Nacional de Seguros Privados - CNSP, para apólices direcionadas a operações da espécie.

$\S 2^{\ominus}$ Sem prejuízo da regulamentação do seguro habitacional pelo CNSP, o Conselho Monetário Nacional estabelecerá as condições necessárias à implementação do disposto no $\$ 1^{0}$-deste artigo, no que se refere às obrigações dos agentes financeiros." (NR) 
Art. 79. Os agentes financeiros do SFH somente poderão conceder financiamentos habitacionais com cobertura securitária que preveja, no mínimo, cobertura aos riscos de morte e invalidez permanente do mutuário e de danos físicos ao imóvel. (Redacãa dada pela Medida Provisória no 478, de 2009)

$\S 1^{\underline{0}}$ Para o cumprimento do disposto no caput, os agentes financeiros, respeitada a livre escolha do mutuário, deverão: (Redação dada pela Medida Provisória ํㅜ 478, de 2009)

I - disponibilizar, na qualidade de estipulante e beneficiário, uma quantidade mínima de apólices emitidas por entes seguradores diversos, que observem a exigência estabelecida no caput; e (Redação dada pela Medida Provisória no 478, de 2009)

II - aceitar apólices individuais apresentadas pelos pretendentes ao financiamento, desde que a cobertura securitária prevista observe a exigência mínima estabelecida no caput e o ente segurador cumpra as condições estabelecidas pelo Conselho Nacional de Seguros Privados - CNSP, para apólices direcionadas a operações da espécie. (Redação dada pela Medida Provisória nำ478, de 2009)

$\S 2^{0}$ Sem prejuízo da regulamentação do seguro habitacional pelo CNSP, o Conselho Monetário Nacional estabelecerá as condições necessárias à implementação do disposto no $\S 1^{\circ}$ deste artigo, no que se refere às obrigações dos agentes financeiros. (Redação dada pela Medida Provisória ํㅡ 478, de 2009)

$\S 3^{0}$ Nas operações em que sejam utilizados recursos advindos do Fundo de Arrendamento Residencial - FAR e do Fundo de Desenvolvimento Social - FDS, os agentes financeiros poderão dispensar a contratação de seguro de que trata o caput, nas hipóteses em que os riscos de morte e invalidez permanente do mutuário e de danos físicos ao imóvel estejam garantidos pelos respectivos Fundos. (Incluído pela Medida Provisória ํㅜ 478, de 2009)

$\S 4^{\circ}$ Nas operações de financiamento na modalidade aquisição de material de construção com recursos do FGTS, os agentes financeiros ficam autorizados a dispensar a contratação do seguro de danos físicos ao imóvel. (Incluído pela Medida Provisória ํo 478, de 2009)

$\S 5^{\circ}$ Nas operações de financiamento de habitação rural, na modalidade aquisição de material de construção, com recursos do FGTS, os agentes financeiros ficam autorizados a dispensar a contratação do seguro de morte e invalidez permanente do mutuário nos casos em que estes riscos contarem com outra garantia. (Incluído pela Medida Provisória n$\underline{478, \text { de 2009) }}$

Art. 80. Até que a quantidade mínima a que se refere o inciso ll do $\$ 1^{\circ}$ do art. $2^{\circ}$ da Medida Provisória $n^{\circ}$ 2.197-43, de 24 de agosto de 2001, seja regulamentada pelo Conselho Monetário Nacional, os agentes financeiros poderão oferecer apenas uma apólice ao mutuário.

Art. 81. Ficam convalidados os atos do Conselho Monetário Nacional que relacionaram as instituições integrantes do Sistema Financeiro da Habitação.

Art. 82. Fica autorizado o financiamento para aquisição de equipamento de energia solar e contratação de mão de obra para sua instalação em moradias cujas famílias aufiram no máximo renda de 6 (seis) salários mínimos.

Art. 83. Esta Lei entra em vigor na data de sua publicação.

Brasília, 7 de julho de 2009; 188 da Independência e 121o da República.

JOSÉ ALENCAR GOMES DA SILVA

Luiz Paulo Teles Ferreira Barreto

Guido Mantega

Paulo Bernardo Silva

Carlos Minc

Marcio Fortes de Almeida

Este texto não substitui o publicado no DOU de 8.7.2009 
ANEXO 4

\author{
PORTARIA CGJ No 207, de 23/11/2009 (ESTADUAL) \\ DJERJ, ADM 57 (32) - 26/11/2009 \\ PORTARIA CGJ № 207/2009
}

CONSIDERANDO o artigo 44, incisos XX, bem como o artigo 17, parágrafo 3 o do CODJERJ, que dispõe que a Corregedoria funciona como órgão de disciplina e correição dos serviços judiciais de primeira instância e extrajudiciais

作 CONSIDERANDO processo administrativo no $\underline{2009 / 136033}$, o parecer de fls. $79 / 86$,

CONSIDERANDO a edição da Lei 11.977, de 07 de julho de 2009 e o conseqüente estabelecimento de uma política nacional de regularização fundiária, bem como a criação de parâmetros para a aquisição de habitação por pessoas de baixa renda;
CONSIDERANDO os direitos constitucionais fundamentais à dignidade da pessoa humana e à moradia esculpidos nos artigos $1^{\circ}$, inciso III, e 6으, da CONSIDERANDO o princípio da veracidade que informa a Constituicãão da Republica; registrais revelarem ocupação e titulação real das áreas, notadamente aquelas de relevante interesse social.
RESOLVE: Art. 1‥ A atuação dos registradores de imóveis no procedimento extrajudicial de Legitimação da Posse, instituído pela Lei 11.977, de 07 de julho de
2009, regula-se por esta portaria.

Parágrafo único. Não se aplica a presente portaria, a regularização fundiária de imóveis de propriedade do Poder Público ou regulada por outra lei. Art. $2^{\circ}$. Os Ofícios de Registro de Imóveis do Estado Rio de Janeiro receberão o requerimento auto de demarcação urbanística elaborado pelo Poder Público, na forma do artigo 56 e que atendam aos requisitos do artigo 59, ambos da Lei 11.977, de 07 de julho de 2009.

Art. 3‥ Recebidos do Poder Público o requerimento de averbação, o registrador o autuará como PROCEDIMENTO DE REGULARIZAÇÃO FUNDIÁRIA e verificará se está acompanhado dos seguintes documentos:

I - planta e memorial descritivo da área a ser regularizada, nos quais constem suas medidas perimetrais, área total, confrontantes, coordenadas preferencialmente georreferenciadas dos vértices definidores de seus limites, bem como seu número de matricula ou transcrição e a indicação do proprietário, se houver;

II - planta de sobreposição do imóvel demarcado com a situação da área constante no registro de imóveis;

IV - as medidas necessárias para promoção da sustentabilidade urbanística, social e ambiental da área ocupada, incluindo as compensações

V - certidão da matricula ou transcrição da área a ser regularizada, emitida pelo registro de imóveis, ou, diante de sua inexistência, das

VI - certidão passada pelo ente estadual competente de que a área pertence ao patrimônio do Estado do Rio de Janeiro, ou a uma de suas autarquias, fundações, empresas públicas ou sociedades de economia mista, se for o caso; autarquias, fundaçoes, empresas públicas ou sociedades de economia mista, se for o caso;
VII - cadastro dos ocupantes, do qual conste a natureza, qualidade e tempo da posse exercida, acrescida das dos antecessores, se for o caso;
VIII - declaração dos ocupantes de não serem possuidores ou proprietários de outro imóvel urbano ou rural;

IX - as condições para promover a segurança da população em situações de risco: $\mathrm{X}$ - minuta do Edital de notificação, na forma do artigo $4^{\circ}$

Parágrafo único. Havendo exigência a ser satisfeita, o registrador comunicará o Poder Público, solicitando a complementação dos documentos, observados os termos do artigo 198, da Lei 6.015 , de 31 de dezembro de 1973.

Art. $4^{\circ}$. Estando completa a documentação do requerimento de averbação, ou informada pelo Poder Público a impossibilidade de cumprir eventua exigência, o registrador elaborará o edital de convocação conforme a minuta apresentada pelo Poder Público e oficiará a Corregedoria Geral da Justiça, encaminhando original e cópia do requerimento, bem como dos documentos que o instruírem.

$\S 1^{\circ}$. Constará do requerimento solicitação para notificação pessoal dos proprietários da área cuja posse será legitimada, indicados pelo Poder Público, e para republicação do edital de notificação previsto no artigo $57, \S 2^{\circ}$ da Lei 11.977, de 07 de julho de 2009.

$\S 2^{\circ}$. A correspondência entre o que constar do auto de demarcação urbanística e a ocupação efetiva da área cuja posse será legitimada, ou dos registros de propriedade, é de responsabilidade do Poder Público requerente.

$\S 3^{\circ}$. Serão notificadas pessoalmente pela Corregedoria Geral da Justiça, as pessoas que constem como proprietárias no Registro de Imóveis, nos endereços indicados no registro ou matrícula.

Art. $5^{\circ}$. Recebido o ofício previsto no artigo $2^{\circ}$, será registrado na Corregedoria Geral da Justiça como Procedimento de Regularização fundiária. $\S 1 \%$. A Corregedoria Geral da Justiça expedirá mandados de intimação pessoal dos proprietários indicados no edital. $\S 2^{\circ}$. As diligências serão efetivadas nos endereços informados pelo Poder Público.

Art. 6․ O edital será publicado, em qualquer caso, duas vezes no Diário Oficial estadual pela Corregedoria Geral da Justiça, cabendo ao Poder Art. $7^{\circ}$. O edital consistirá na intimaçãa dos proprietários que constem dos registros dos imóveis da área cujas posses pretende-se legitimar e eventuais interessados, devendo conter:

I - O nome do proprietário que conste do registro ou matrícula cuja posse será legitimada;

II - O endereço do proprietário que conste do registro ou matrícula;

III - O número do procedimento de regularização no ofício de registro de imóveis e indicação de todos os documentos referidos no artigo $3^{\circ}$.

IV - O endereço do cartório de registro de imóveis onde deverão ser apresentadas eventuais impugnações, na forma do artigo tal da Lei 11.977, de 07 de julho de 2009.

V - A advertência de que se não for apresentada impugnação no cartório de registro de imóveis em 15 dias, será anotada a legitimidade da posse das pessoas indicadas no auto de demarcação apresentado pelo Poder Público, findo o respectivo processo.

Art. 8ㅇ. Havendo apresentação de impugnação, o registrador imediatamente comunicará a Corregedoria Geral da Justiça, que mediará a

$\S 1$. Somente será aceita impugnação apresentada por pessoa que conste no registro ou matrícula como proprietária do imóvel cuja posse será

§2․ A Corregedoria Geral da Justiça intimará o Poder Público a participar da mediação, bem como para a finalidade do artigo 57 , parágrafos $6^{\circ} \mathrm{e}$ $7^{\circ}$ da Lei 11.977, de 07 de julho de 2009;

$\S 3^{\circ}$. Passados sessenta dias da intimação do parágrafo anterior e não obtida a composição com o proprietário impugnante, nem apresentada pelo

Poder Público a retificação ao auto de demarcação na forma do artigo tal da lei, será arquivada a impugnação e excluída a área impugnada da averbação da demarcação.

§4. O Procedimento de Regularização fundiária prosseguirá quanto às áreas não impugnadas.

Art. 9‥ Não havendo impugnações, sanadas as que forem apresentadas ou prosseguindo o Procedimento de Regularização fundiária quanto à parte não impugnada, o registrador abrirá nova matrícula da área do auto de demarcação apresentado pelo Poder Público.

$\S 1$. O registrador anotará na nova matrícula da área descrita no auto de demarcação que não há proprietário, salientando que o faz nos termos da Lei 11.977 , de 07 de julho de 2009 e deste provimento.

$\S 2^{\circ}$. O registrador averbará nas matrículas e registros anteriores a referência a essa nova matrícula.

$\S 3$ ‥ Aberta a nova matrícula, não poderão mais ocorrer anotações de transmissão de direitos na matrícula encerrada.

Art. 10. Aberta a matrícula da área do auto de demarcação, o Poder Público será comunicado para proceder ao exame do projeto de regularização undiária previsto no artigo 51 da Lei 11.977, de 07 de julho de 2009.

Art. 11. O Poder Público encaminhará ao ofício de registro de imóveis o projeto aprovado de regularização fundiária, que valerá como título de Legitimação da Posse, e o registrador averbará o referido projeto, anotando a demarcação e, no mesmo momento, o nome do legitimo possuidor de cada lote e fração, apontado pelo Poder Público no auto de demarcacão.

$\S 1^{\circ}$. Não se averbará a demarcação se não for apresentada simultaneamente a relação dos legítimos possuidores de cada lote e fração identificados no Procedimento de Regularização fundiária.

$\S 2^{\circ}$. A legitimidade fática e jurídica da posse da pessoa indicada no requerimento é responsabilidade do Poder Público solicitante da averbação. $\S 3 \%$. O registro dos legítimos possuidores correspondentes a cada lote e fração poderá ser complementado pelo prazo de um ano, a contar da averbação do projeto, mediante novo levantamento e publicação de novos editais, e, após verificação pela Corregedoria Geral da Justiça. Legitimação da Posse, poderá requerer ao oficial de registro de imóveis a conversão desse título em registro em propriedade, tendo em vista sua aquisição por usucapião, nos termos do artigo 183 da ĆConstituição Federal de 1988. Art. 13. Revogam-se as disposições em contrário.

Art. 14. Este Provimento entra em vigor na data de sua publicação.

Rio de Janeiro, 23 de novembro de 2009.

GUSTAVO QUINTANILHA TELLES DE MENEZES

Juiz Auxiliar da Corregedoria Geral de Justiça 


\section{ANEXO 5}

\section{PROVIMENTO № 28/2004-CGJ}

INSTITUI O PROJETO "MORE LEGAL 3"

O EXCELENTÍSSIMO DESEMBARGADOR ARISTIDES PEDROSO DE ALBUQUERQUE NETO, DIGNÍSSIMO CORREGEDOR-GERAL DA JUSTIÇA DO ESTADO DO RIO GRANDE DO SUL, NO USO DE SUAS ATRIBUIÇÕES LEGAIS,

CONSIDERANDO QUE A INTEGRIDADE DAS NORMAS DE LEGISLAÇÃO ORDINÁRIA SOBRE AQUISIČ̃̃O, PERDA E FUNÇÃO DA PROPRIEDADE IMÓVEL DEVEM SER VISTAS, PARA A PRESERVAÇÃO DA UNIDADE INTERNA E COERẾNCIA DO SISTEMA JURÍDICO, ATRAVÉS DO PRISMA DOS OBJETIVOS CONSTITUCIONAIS;

CONSIDERANDO QUE A INVIOLABILIDADE DO DIREITO À PROPRIEDADE MERECE SER DIMENSIONADA EM HARMONIA COM O PRINCÍPIO, TAMBÉM CONSTITUCIONAL, DE SUA FUNÇÃO SOCIAL;

CONSIDERANDO QUE A CONSTRUÇÃO DE UM ESTADO DEMOCRÁTICO DE DIREITO, EM QUE A PLENITUDE DO EXERCÍCIO DA CIDADANIA, COM O RESGUARDO DOS VALORES MÍNIMOS DA DIGNIDADE HUMANA, AVULTA COM UM DE SEUS AUTÊNTICOS OBJETIVOS FUNDAMENTAIS

CONSIDERANDO QUE A MODERNA FUNÇÃO DO DIREITO NÃO SE LIMITA APENAS À CLÁSSICA SOLUÇÃO CONCEITUAL DE CONFLITOS DE INTERESSES E DE GERAÇÃO DE SEGURANÇA JURÍDICA, MAS DEVE PROPICIAR CONDIÇÕES PARA A VALORIZAÇÃO DA CIDADANIA E PROMOVER A JUSTIÇA SOCIAL;

CONSIDERANDO QUE UM DOS OBJETIVOS DAS REGRAS LEGAIS REGULAMENTADORAS DO SOLO URBANO SEMPRE VISOU À PROTECÃO JURÍDICA DOS ADQUIRENTES DE IMÓVEIS, ESPECIALMENTE QUANDO INTEGRANTES DE LOTEAMENTOS OU PARCELAMENTOS ASSEMELHADOS;

CONSIDERANDO QUE A CARTA MAGNA, AO CONSAGRAR O DIREITO DE PROPRIEDADE, NÃO ESTABELECEU LIMITACOÕES OUTRAS, ASSEGURANDO AO CIDADÃO, ALÉM DO ACESSO E DA POSSE, A DECORRENTE E IMPRESCINDÍVEL TITULAÇÃO, PORQUE SÓ COM A IMPLEMENTAÇÃO DESTE REQUISITO TORNA-SE POSSÍVEL SEU PLENO EXERCÍCIO:

CONSIDERANDO QUE A ORGANIZAÇÃO DAS NAÇÕES UNIDAS (ONU), DA QUAL O BRASIL É INTEGRANTE, ESTABELECEU CONVENÇÃO NO SENTIDO DE QUE A MORADIA CONSTITUI-SE EM DIREITO SOCIAL FUNDAMENTAL DO CIDADÃO;

CONSIDERANDO QUE A EMENDA CONSTITUCIONAL № 26, DE 14 DE FEVEREIRO DE 2000, INCLUIU ENTRE OS PRECEITOS DA CONSTITUIÇÃO FEDERAL DO BRASIL A MORADIA COMO DIREITO SOCIAL FUNDAMENTAL;

CONSIDERANDO QUE OS FRACIONAMENTOS, MESMO QUANDO NÃO PLANEJADOS OU AUTORIZADOS ADMINISTRATIVAMENTE DE

FORMA EXPRESSA, GERAM, EM MUITAS HIPÓTESES, SITUAÇÕES FÁTICAS CONSOLIDADAS E IRREVERSÍVEIS, ADQUIRINDO AS UNIDADES DESMEMBRADAS AUTONOMIA JURÍDICA E DESTINAÇÃO SOCIAL COMPATÍVEL, COM EVIDENTE REPERCUSSÃO NA ORDEM JURÍDICA

CONSIDERANDO QUE O ESTATUTO DA CIDADE (LEI 10.257, DE 10 DE JULHO DE 2001) ESTABELECE, EM SEU ARTIGO $2^{\circ}$, INCISO I, QUE A POLITICA URBANA TEM, ENTRE SUAS DIRETRIZES BÁSICAS, O DIREITO DO CIDADÃO À TERRA URBANA E À MORADIA, PARA AS PRESENTES E FUTURAS GERAÇÕES, NO INTUITO DE ORDENAR O PLENO DESENVOLVIMENTO DAS FUNÇÕES SOCIAIS DA CIDADE E DA PROPRIEDADE URBANA;

CONSIDERANDO QUE O REFERIDO ESTATUTO DA CIDADE, EM SEU ARTIGO 2o, INCISOS VI E XIV, ESTABELECE, AINDA, COMO DIRETRIZES DA POLÍTICA URBANA A ORDENACÃO E CONTROLE DO USO DO SOLO URBANO, O ESTABELECIMENTO DE NORMAS ESPECIAIS DE URBANIZAÇÃO, USO E OCUPAÇÃO DO SOLO E EDIFICAÇÃO, PARA A REGULARIZAÇÃO FUNDIÁRIA E URBANIZAÇÃO DE ÁREAS OCUPADAS POR POPULAÇÃO DE BAIXA RENDA;

CONSIDERANDO QUE EVENTUAL ANOMALIA NO REGISTRO PODE SER ALVO DE AÇÃO PRÓPRIA OBJETIVANDO A ANULAÇÃO EM PROCESSO CONTENCIOSO (ARTIGO 216 DA LEI 6.015, DE 31 DE DEZEMBRO DE 1973 - LEI DOS REGISTROS PÚBLICOS);

CONSIDERANDO O PECULIAR INTERESSE DOS MUNICÍPIOS GAÚCHOS EM REGULARIZAR A OCUPAÇÃO DE ÁREAS SITUADAS EM SEU PERÍMETRO URBANO OU PERIFERIA, SEM VIOLAÇÃO AO MEIO-AMBIENTE, PARA PROVÊ-LAS DE INFRA-ESTRUTURA NECESSÁRIA A UMA VIDA DIGNA;

CONSIDERANDO A MOTIVAÇÃO INSERIDA NA MENSAGEM “JUIZ, TUTOR DA CIDADANIA”, DESTA CORREGEDORIA, PUBLICADA NO DIÁRIO DA JUSTIÇA DO DIA 10 DE AGOSTO DE 1995;

CONSIDERANDO SEJA IMPRESCINDÍVEL ASSEGURAR A PARTICIPAÇ̃̃O DO MINISTÉRIO PÚBLICO, COMO INSTITUIÇÃO EM SI ESSENCIAL E DEFENSORA CONSTITUCIONAL DOS INTERESSES SOCIAIS, GARANTINDO-SE, COM A EFETIVIDADE DE SUA PARTICIPAÇÃO, A SOLUÇÃO PARA GRANDE NÚMERO DE SITUAÇÕES EXISTENTES; 
CONSIDERANDO O EMPENHO DE NOTÁRIOS E REGISTRADORES DE IMÓVEIS, DEMONSTRADO PELOS RESPECTIVOS COLÉGIOS E ASSOCIAÇÕES, PARA QUE, COM SEGURANÇA JURÍDICA POSSAM SER ALCANÇADAS AS SOLUÇÕES EXIGÍVEIS;

CONSIDERANDO A EDIÇÃO DA LEI 9.785, DE 29 DE JANEIRO DE 1999, QUE ALTEROU O DECRETO-LEI 3.365, DE 21 DE JUNHO DE 1941, AS LEIS 6.015, DE 31 DE DEZEMBRO DE 1973 (LEI DOS REGISTROS PÚBLICOS), 6.766, DE 19 DE DEZEMBRO DE 1979 (LEI DO PARCELAMENTO DO SOLO URBANO), 10.257, DE 10 DE JULHO DE 2001 (ESTATUTO DA CIDADE) E 10.931, DE 02 DE AGOSTO DE 2004, QUE ALTEROU O PROCEDIMENTO DE RETIFICAÇÃO NO REGISTRO IMOBILIÁRIO;

CONSIDERANDO QUE O ARTIGO 53 DA LEI 9.785, DE 29 DE JANEIRO DE 1999, EXPRESSOU SER DO INTERESSE PÚBLICO O PARCELAMENTO DO SOLO, BEM ASSIM SUA REGULARIZAÇÃO, VEDANDO EXIGÊNCIAS OUTRAS QUE NÃO A DOCUMENTAÇÃO MÍNIMA NECESSÁRIA AO REGISTRO;

CONSIDERANDO QUE O ARTIGO 2º, INCISO XV, DO JÁ REFERIDO ESTATUTO DA CIDADE, ESTABELECE A SIMPLIFICAÇÃO DA LEGISLAÇÃO DE PARCELAMENTO, USO E OCUPAÇÃO DO SOLO E DAS NORMAS EDILÍCIAS, COM VISTAS A PERMITIR A REDUÇÃO DOS CUSTOS E O AUMENTO DA OFERTA DOS LOTES E UNIDADES HABITACIONAIS;

CONSIDERANDO A INSTITUIÇÃO DE COMISSÃO REVISORA DO PROJETO "MORE LEGAL 2", FORMADA POR INTEGRANTES DO PODER JUDICIÁRIO E DO MINISTÉRIO PÚBLICO DO RGS, TABELIÃES E REGISTRADORES PÚBLICOS,

\section{RESOLVE PROVER:}

\section{TÍTULO I}

\section{DAS DISPOSIÇÕES GERAIS}

ART. 1ํ - A REGULARIZAÇÃO E REGISTRO DE LOTEAMENTO, DESMEMBRAMENTO, FRACIONAMENTO OU DESDOBRO DE IMÓVEIS URBANOS OU URBANIZADOS, AINDA QUE LOCALIZADOS EM ZONA RURAL, NOS CASOS ESPECIFICADOS, OBEDECERÁ AO DISPOSTO NESTE PROVIMENTO.

§ 1ํ - FICAM EXCLUÍDAS AS ÁREAS DE PRESERVAÇÃO PERMANENTE E LEGAL, UNIDADES DE CONSERVAÇÃO DE PROTEÇÃO INTEGRAL, TERRAS INDÍGENAS E OUTROS CASOS PREVISTOS EM LEI.

§ $2^{\circ}$ - AS ÁREAS DE RISCO FICAM CONDICIONADAS À SATISFAÇÃO DAS EXIGÊNCIAS PREVISTAS NO PARÁGRAFO ÚNICO DO ARTIGO 3ำ DA LEI № 6.766/79.

\section{TíTULO II}

\section{DA REGULARIZAÇÃO DO PARCELAMENTO}

ART. 20 - NAS COMARCAS DO ESTADO DO RIO GRANDE DO SUL, EM SITUAÇÕES CONSOLIDADAS, PODERÁ A AUTORIDADE JUDICIÁRIA COMPETENTE AUTORIZAR OU DETERMINAR O REGISTRO ACOMPANHADO DOS SEGUINTES DOCUMENTOS:

I - TÍTULO DE PROPRIEDADE DO IMÓVEL OU, NAS HIPÓTESES DOS §§ 3ํㅡ E $4^{\circ}$ DESTE ARTIGO, APENAS A CERTIDÃO DA MATRÍCULA;

II - CERTIDÃO DE AÇÃO REAL OU REIPERSECUTÓRIA, DE ÔNUS REAIS E OUTROS GRAVAMES, REFERENTE AO IMÓVEL, EXPEDIDA PELO OFÍCIO DO REGISTRO DE IMÓVEIS;

III - PLANTA DO IMÓVEL E MEMORIAL DESCRITIVO, EMITIDOS OU APROVADOS PELO MUNICÍPIO.

§ 1ํ. - CONSIDERA-SE SITUAÇÃO CONSOLIDADA AQUELA EM QUE O PRAZO DE OCUPAÇÃO DA ÁREA, A NATUREZA DAS EDIFICAÇÕES EXISTENTES, A LOCALIZAÇÃO DAS VIAS DE CIRCULAÇÃO OU COMUNICAÇÃO, OS EQUIPAMENTOS PÚBLICOS DISPONÍVEIS, URBANOS OU COMUNITÁRIOS, DENTRE OUTRAS SITUAÇÕES PECULIARES, INDIQUE A IRREVERSIBILIDADE DA POSSE TITULADA QUE INDUZA AO DOMINIO.

$\S 2^{\circ}$ - NA AFERIÇÃO DA SITUAÇÃO JURÍDICA CONSOLIDADA, SERÃO VALORIZADOS QUAISQUER DOCUMENTOS PROVENIENTES DO PODER PÚBLICO, EM ESPECIAL DO MUNICÍPIO.

§ 3ำ - O TÍTULO DE PROPRIEDADE SERÁ DISPENSADO QUANDO SE TRATAR DE PARCELAMENTO POPULAR, DESTINADO ÀS CLASSES DE MENOR RENDA, EM IMÓVEL DECLARADO DE UTILIDADE PÚBLICA COM PROCESSO DE DESAPROPRIAÇÃO JUDICIAL EM CURSO E IMISSÃO PROVISÓRIA NA POSSE, DESDE QUE PROMOVIDO PELA UNIÃO, ESTADO OU MUNICÍPIOS, OU SUAS ENTIDADES DELEGADAS, AUTORIZADAS POR LEI A IMPLANTAR PROJETOS DE HABITAÇÃO.

$\S 4^{\circ}$ - NO CASO DE QUE TRATA O §3ํㅗㄴ, SUPRA, O PEDIDO DE REGISTRO DO PARCELAMENTO, ALÉM DO DOCUMENTO MENCIONADO NO ARTIGO 18, INCISO V, DA LEI № 6.766/79, SERÁ INSTRUÍDO COM CÓPIAS AUTÊNTICAS DA DECISÃO QUE TENHA CONCEDIDO A IMISSÃO PROVISÓRIA NA POSSE, DO DECRETO DE DESAPROPRIACCÃO, DO COMPROVANTE DE SUA PUBLICACCÃO NA IMPRENSA OFICIAL E, QUANDO FORMULADO POR ENTIDADE DELEGADA, DA LEI DE CRIAÇÃO E DE SEU ATO CONSTITUTIVO. 
§ $5^{\circ}$ - NAS REGULARIZAÇÕES COLETIVAS PODERÁ SER DETERMINADA A APRESENTAC̄̃̃ DE MEMORIAL DESCRITIVO ELABORADO PELO MUNICÍPIO, OU POR ELE APROVADO, ABRANGENDO A DIVISÃO DA TOTALIDADE DA ÁREA OU A SUBDIVISÃO DE APENAS UMA OU MAIS QUADRAS.

ART. $3^{\circ}$ - TRATANDO-SE DE IMÓVEL PÚBLICO OU SUBMETIDO À INTERVENÇÃO DO PODER PÚBLICO, INTEGRANTE DE ÁREA ESPECIAL DE INTERESSE SOCIAL, PODERÁ A AUTORIDADE JUDICIÁRIA COMPETENTE AUTORIZAR OU DETERMINAR O REGISTRO ACOMPANHADO DOS DOCUMENTOS INDICADOS NO ARTIGO ANTERIOR.

PARÁGRAFO ÚNICO - NÃO SÃO DEVIDAS CUSTAS OU EMOLUMENTOS NOTARIAIS OU DE REGISTRO DECORRENTES DE REGULARIZAÇÃO FUNDIÁRIA DE INTERESSE SOCIAL, ASSIM RECONHECIDA POR LEI MUNICIPAL, A CARGO DA ADMINISTRAÇÃO PÚBLICA.

ART. $4^{\circ}$ - NOS CASOS DE REGULARIZACÃO PELO PODER PÚBLICO, CONFORME AUTORIZADO PELO ARTIGO 40 DA LEI № 6.766/79, PODERÁ O JUIZ DE DIREITO AUTORIZAR OU DETERMINAR O REGISTRO NAS MESMAS CONDIÇÕES, SEM PREJUÍZO DE ADOÇÃO DE OUTRAS MEDIDAS, CIVVEIS, CRIMINAIS OU ADMINISTRATIVAS CONTRA O LOTEADOR FALTOSO.

§ 1- - ATRAVÉS DE REQUERIMENTO FUNDAMENTADO E COM PARECER FAVORÁVEL DO MINISTÉRIO PÚBLICO, PODERÁ AINDA O JUIZ, CONCEDER ALVARÁ DE AUTORIZAÇÃO PARA O MUNICÍPIO FIRMAR CONTRATOS DE ALIENAÇÃO DE IMÓVEIS PENDENTES E PROMOVER A VENDA DOS LOTES REMANESCENTES, REVERTENDO A QUANTIA APURADA EM BENEFÍCIO DA MUNICIPALIDADE PARA RESSARCIMENTO DAS DESPESAS DECORRENTES DA REGULARIZAÇÃO.

§ 2 - O REQUERIMENTO DE QUE TRATA O PARÁGRAFO ANTERIOR, DEVERÁ SER INSTRUÍDO COM DOCUMENTOS, PÚBLICOS OU PRIVADOS, E APRESENTAÇÃO DO RESPECTIVO LAUDO DE AVALIAÇÃO DOS LOTES, FIRMADO POR PROFISSIONAL HABILITADO, SENDO FACULTADA, AINDA, A COMPROVAÇÃO DAS DESPESAS ATRAVÉS DE PROVA TESTEMUNHAL.

$\S 3$ - HAVENDO DÚVIDA SOBRE OS VALORES GASTOS PELA MUNICIPALIDADE NA REGULARIZAÇÃO E AVALIAÇÃO DOS LOTES, O JUIZ PODERÁ, DE OFÍCIO OU MEDIANTE REQUERIMENTO DO MINISTÉRIO PÚBLICO, DETERMINAR A REALIZAÇÃO DAS DILIGÊNCIAS OU PERÍCIAS QUE ENTENDER CABIIVEIS

ART. $5^{\circ}$ - NAS HIPÓTESES DE REGULARIZAÇÃO PREVISTAS NO PRESENTE TíTULO, A AUTORIDADE JUDICIÁRIA PODERÁ PERMITIR O REGISTRO, EMBORA NÃO ATENDIDOS OS REQUISITOS URBANÍSTICOS PREVISTOS NA LEI № 6.766/79 OU EM OUTROS DIPLOMAS LEGAIS.

\section{TíTULO III}

\section{DO REGISTRO DOS CONTRATOS}

ART. 60 - REGISTRADO OU AVERBADO O PARCELAMENTO (LOTEAMENTO, DESDOBRAMENTO, FRACIONAMENTO OU DESDOBRO) DO SOLO URBANO, OS ADQUIRENTES DE LOTES DE TERRENO PODERÃO REQUERER O REGISTRO DOS SEUS CONTRATOS, PADRONIZADOS OU NÃO, APRESENTANDO O RESPECTIVO INSTRUMENTO JUNTO AO OFÍCIO DO REGISTRO DE IMÓVEIS.

§ 1- - O REGISTRO PODERÁ SER OBTIDO DIANTE DA COMPROVAÇÃO IDÔNEA DA EXISTÊNCIA DO CONTRATO, NOS TERMOS DO ARTIGO 27, §1ํㅡ E §2ำ, DA LEI № 6.766/79.

$\S 2^{\circ}$ - OS REQUISITOS DE QUALIFICAÇÃO DAS PARTES NECESSÁRIOS AO REGISTRO, CASO INEXISTENTES, SERÃO COMPROVADOS ATRAVÉS DA APRESENTAÇÃO DE CÓPIA AUTENTICADA DE DOCUMENTO PESSOAL DE IDENTIFICAÇÃO, OU DOS COGITADOS NA LEI № 9.049, DE 18 DE MAIO DE 1995, OU, AINDA, DE CÓPIA DE CERTIDÃO DE CASAMENTO OU EQUIVALENTE.

$\S 3^{\circ}-$ - ADMITE-SE, NOS PARCELAMENTOS POPULARES, A CESSÃO DA POSSE EM QUE ESTIVEREM PROVISORIAMENTE IMITIDAS A UNIÃO, ESTADO OU MUNICÍPIOS, E SUAS ENTIDADES DELEGADAS, O QUE PODERÁ OCORRER POR INSTRUMENTO PARTICULAR.

$\S 4^{\circ}$ - A CESSÃO DA POSSE REFERIDA NO §3ํ, CUMPRIDAS AS OBRIGAÇÕES DO CESSIONÁRIO, CONSTITUI CRÉDITO CONTRA O EXPROPRIANTE, DE ACEITAÇÃO OBRIGATÓRIA EM GARANTIA DE CONTRATOS DE FINANCIAMENTOS HABITACIONAIS.

§ 50 - COM O REGISTRO DA SENTENCA QUE, EM PROCESSO DE DESAPROPRIACÃO, FIXAR O VALOR DA INDENIZAC̄̃O, A POSSE REFERIDA NO §3ํㅡㄴ CONVERTER-SE-Á EM PROPRIEDADE, E A SUA CESSÃO EM COMPROMISSO DE COMPRA E VENDA, CONFORME HAJA OBRIGAÇÕES A CUMPRIR OU ESTEJAM ELAS CUMPRIDAS, CIRCUNSTÂNCIAS QUE, DEMONSTRADAS NO REGISTRO DE IMÓVEIS, SERÃO AVERBADAS NA MATRÍCULA RELATIVA AO LOTE.

$\S 6^{\circ}$ - OS COMPROMISSOS DE COMPRA E VENDA, AS CESSÕES E AS PROMESSAS DE CESSÃO, VALERÃO COMO TÍTULO PARA O REGISTRO DA PROPRIEDADE DO LOTE ADQUIRIDO, QUANDO ACOMPANHADOS DA RESPECTIVA PROVA DE QUITACÃO DAS OBRIGAÇÕES DO ADQUIRENTE E DE GUIA DE PAGAMENTO OU DE EXONERAÇÃO DO ITBI, REGISTRO ESSE QUE SERÁ FEITO A

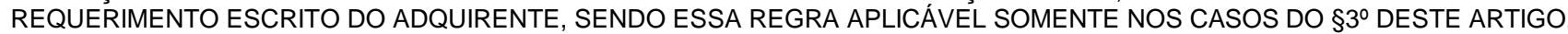

\section{TíTULO IV}

\section{DA LOCALIZAÇÃO DE ÁREAS EM CONDOMÍNIO}


ART. 7ํ - EM IMÓVEIS SITUADOS NOS PERÍMETROS URBANOS, ASSIM COMO NOS LOCAIS URBANIZADOS, AINDA QUE SITUADOS NA ZONA RURAL, EM CUJOS ASSENTOS CONSTE ESTADO DE COMUNHÃO, MAS QUE, NA REALIDADE, SE APRESENTAM INDIVIDUALIZADOS E

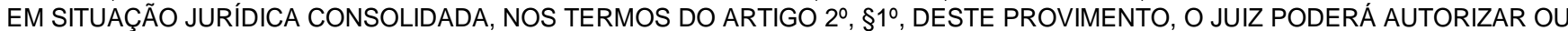
DETERMINAR A AVERBAÇÃO DA IDENTIFICAÇÃO DE UMA OU DE CADA UMA DAS FRAÇÕES, OBSERVADO O SEGUINTE:

I - ANUÊNCIA DOS CONFRONTANTES DA FRAÇÃO DO IMÓVEL QUE SE QUER LOCALIZAR, EXPRESSA EM INSTRUMENTO PÚBLICO OU PARTICULAR, NESTE CASO COM AS ASSINATURAS RECONHECIDAS POR AUTENTICIDADE, ENTENDIDOS COMO CONFRONTANTES AQUELES PREVISTOS NO §10 DO ARTIGO 213 DA LEI № 6.015/73.

II - A IDENTIFICAÇÃO DA FRAÇÃO DE ACORDO COM O DISPOSTO NOS ARTIGOS 176, INCISO II, N. 3, LETRA B, E 225 DA LEI № 6.015/73, ATRAVÉS DE CERTIDÃO ATUALIZADA EXPEDIDA PELO PODER PÚBLICO MUNICIPAL.

ART. 8ㅇ - PROCEDIDO O REGISTRO PREVISTO PELOS ARTIGOS $2^{\circ}$ E $3^{\circ}$, E A AVERBAÇÃO REGULADA PELO ARTIGO $7^{\circ}$ DESTE PROVIMENTO, O OFICIAL DO REGISTRO DE IMÓVEIS ABRIRÁ MATRÍCULA PRÓPRIA, SE O IMÓVEL AINDA NÃO A TIVER, BEM COMO DAS ÁREAS PÚBLICAS PREVISTAS NO PROJETO.

\section{TíTULO V}

\section{DO PROCEDIMENTO}

ART. 9 - O PEDIDO DE REGULARIZAÇÃO DO LOTE INDIVIDUALIZADO, DE QUARTEIRÃO OU DA TOTALIDADE DA ÁREA, SERÁ APRESENTADO PERANTE O OFÍCIO DO REGISTRO IMOBILIÁRIO DA SITUAÇÃO DO IMÓVEL, ONDE SERÁ PROTOCOLADO E AUTUADO, VERIFICADA SUA REGULARIDADE EM ATENÇÃO AOS PRINCÍPIOS REGISTRAIS.

$\S 1^{\circ}$ - ESTANDO EM ORDEM, O PEDIDO SERÁ REMETIDO À VARA DA DIREÇÃO DO FORO, NO INTERIOR DO ESTADO, E À VARA DOS REGISTROS PÚBLICOS, NA COMARCA DA CAPITAL, PARA DECISÃO, QUE SOMENTE SERÁ PROLATADA APÓS MANIFESTAÇÃO DO ÓRGÃO DO MINISTÉRIO PÚBLICO.

§ 2ํ - HAVENDO EXIGÊNCIA A SER SATISFEITA, O OFICIAL INDICA-LA-Á POR ESCRITO. NÃO SE CONFORMANDO O APRESENTANTE, REQUERERÁ QUE O OFICIAL REMETA A DOCUMENTAÇÃO AO JUIZ DE DIREITO COMPETENTE PARA A APRECIAÇÃO CONJUNTA DA EXIGÊNCIA E DO PEDIDO DE REGULARIZAÇÃO.

§ 3ํ - O JUIZ DE DIREITO PODERÁ SUSPENDER O JULGAMENTO E DETERMINAR A PUBLICAÇÃO DE EDITAL PARA CONHECIMENTO DE TERCEIROS.

§ 4 - O PROCEDIMENTO SERÁ REGIDO PELAS NORMAS QUE REGULAM A JURISDIÇÃO VOLUNTÁRIA, APLICANDO-SE, NO QUE COUBER, A LEI № 6.015/73, ATENDENDO-SE AOS CRITÉRIOS DE CONVENIÊNCIA E/OU OPORTUNIDADE.

§ 5 - TRANSITADA EM JULGADO A SENTENÇA, OS AUTOS DO PROCESSO SERÃO REMETIDOS AO OFÍCIO DO REGISTRO DE IMÓVEIS PARA CUMPRIMENTO DAS DETERMINAÇÕES JUDICIAIS E ARQUIVAMENTO.

ART. 10 - NO CASO DE A ÁREA PARCELADA NÃO COINCIDIR COM A DESCRIÇÃO CONSTANTE NO REGISTRO IMOBILIÁRIO, O JUIZ DETERMINARÁ A RETIFICAÇÃO DA DESCRIÇÃO DO IMÓVEL COM BASE NA RESPECTIVA PLANTA E NO MEMORIAL DESCRITIVO.

ART. 11 - OS LINDEIROS QUE NÃO TENHAM ANUÍDO SERÃO CIENTIFICADOS NA FORMA DO ARTIGO 213, INCISO II, §§ 2ํㅡ $3^{\circ}$, COM A COMINAÇÃO DO § 4ำ, DA LEI 6.015/73.

ART. 12 - O REGISTRO E A RESPECTIVA MATRÍCULA PODERÃO SER CANCELADOS EM PROCESSO CONTENCIOSO, POR INICIATIVA DE TERCEIRO PREJUDICADO OU DO MINISTÉRIO PÚBLICO, NOS CASOS PREVISTOS EM LEI, EM ESPECIAL NAS HIPÓTESES DO ARTIGO 216 DA LEI № 6.015/73.

PARÁGRAFO ÚNICO - SE O JUIZ CONSTATAR QUE A ABERTURA DE MATRÍCULA OU ALGUM ATO POR ELE AUTORIZADO NOS TERMOS DESTE PROVIMENTO SEJAM NULOS OU ANULÁVEIS, DETERMINARÁ, FUNDAMENTADAMENTE E DE OFÍCIO, O RESPECTIVO CANCELAMENTO, OU ALCANÇARÁ ELEMENTOS AO ÓRGÃO DO MINISTÉRIO PÚBLICO PARA AS PROVIDÊNCIAS CABÍVEIS.

\section{TÍTULO VI}

\section{DAS AÇÕES DE USUCAPIÃO}

ART. 13 - NA EVENTUAL IMPOSSIBILIDADE DE REGULARIZAÇÃO E REGISTRO DE LOTEAMENTO, DESMEMBRAMENTO OU DESDOBRO DE IMÓVEL URBANIZADO, LOCALIZADO NA ZONA URBANA OU RURAL, COM FUNDAMENTO NO PRESENTE PROVIMENTO, RECOMENDA-SE O AJUIZAMENTO DE AÇÃO DE USUCAPIÃO.

PARÁGRAFO ÚNICO - AS CERTIDÕES NECESSÁRIAS À INSTRUÇÃO DO PROCESSO DE USUCAPIÃO, SENDO O AUTOR BENEFICIÁRIO DA ASSISTÊNCIA JUDICIÁRIA, PODERÃO SER REQUISITADAS PELO JUIZ GRATUITAMENTE. 


\section{DAS DISPOSIÇÕES FINAIS}

ART. 14 - HAVENDO IMPUGNAÇÃO AO PEDIDO DE REGULARIZAÇÃO E REGISTRO EM QUALQUER FASE DO PROCEDIMENTO, DEVERÁ A AUTORIDADE JUDICIÁRIA REMETER OS INTERESSADOS ÀS VIAS ORDINÁRIAS.

PARÁGRAFO ÚNICO - ENTENDENDO O JUIZ DE DIREITO QUE A IMPUGNAÇÃO É MANIFESTAMENTE INADMISSÍVEL OU IMPROCEDENTE, PODERÁ REJEITÁ-LA DE PLANO, JULGANDO IMEDIATAMENTE O PEDIDO INICIAL.

ART. 15 - AO RECEBER TÍTULO PARA REGISTRO EM SUA SERVENTIA, CUJO CONTEÚDO CONTENHA INDÍCIO OU EVIDÊNCIA DE LOTEAMENTO IRREGULAR OU CLANDESTINO, O OFICIAL DO REGISTRO DE IMÓVEIS DEVERÁ IMPUGNÁ-LO, NOTICIANDO O FATO IMEDIATAMENTE AO REPRESENTANTE DO MINISTÉRIO PÚBLICO LOCAL.

ART. 16 - PROCEDIDA A REGULARIZAÇÃO NOS TERMOS DO PRESENTE PROVIMENTO, O REGISTRADOR COMUNICARÁ O FATO À MUNICIPALIDADE.

ART. 17 - ESTE PROVIMENTO ENTRARÁ EM VIGOR NA DATA DE SUA PUBLICAÇÃO, REVOGADAS AS DISPOSIÇÕES EM CONTRÁRIO.

PORTO ALEGRE, 28 DE OUTUBRO DE 2004.

PUBLIQUE-SE.

CUMPRA-SE.

DES. ARISTIDES PEDROSO DE ALBUQUERQUE NETO

CORREGEDOR-GERAL DA JUSTIÇA.

REGISTRE-SE E PUBLIQUE-SE.

VALÉRIA GAMBOGI RODRIGUES

SECRETÁRIA DA CGJ 
93

Pontificia Universidade Católica

DO RIO DE JANEIRO

NORMAS PARA ELABORAÇÃO E APRESENTAÇÃO DA MONOGRAFIA

JUR 1919

ANEXO II

A Monografia deve ser entregue até o dia 03 de junho de 2010.

A presente Monografia, apresentada pelo(a) aluno(a)

Paloma de Azevedo Corréa

, poderá ser submetida à exposição e defesa perante a

Banca Examinadora designada pelo Departamento de Direito da PUC-Rio.

Rio de Janeiro, 08 de funhte de 2010.

Rosângela Lunardelli cavallazzi

Nome do(a) professor(a) orientador(a)

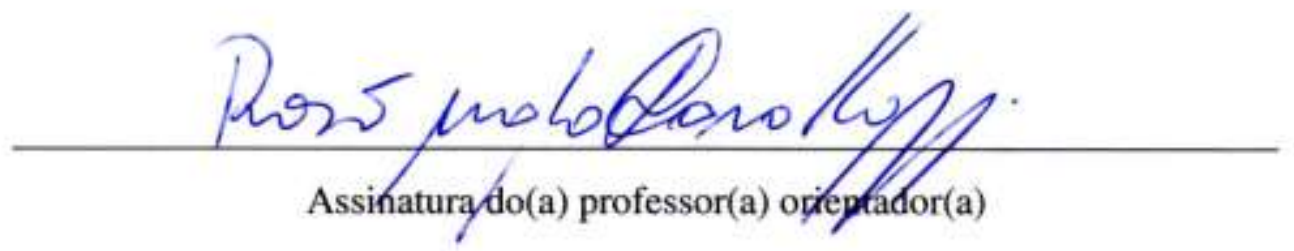

$\mathrm{O}(\mathrm{A})$ autor(a) deste trabalho autoriza o Departamento de Direito da PUC-Rio a divulgálo, no todo ou em parte, resguardados os direitos autorais conforme legislação vigente.

Rio de Janeiro, O8 de funh 2010.

Palaua de dgevedolonéa

Assinatura do(a) aluno(a) 
